\title{
Kazan Golovkinsky Stratigraphic Meeting 2021
} celebrating the 180th anniversary of the establishment of the Permian system

"Sedimentary Earth Systems: Stratigraphy, Paleoclimate, Geochronology, Petroleum Resources"

Sixth All-Russian Conference "Upper Paleozoic of Russia"

\section{ABSTRACT VOLUME}




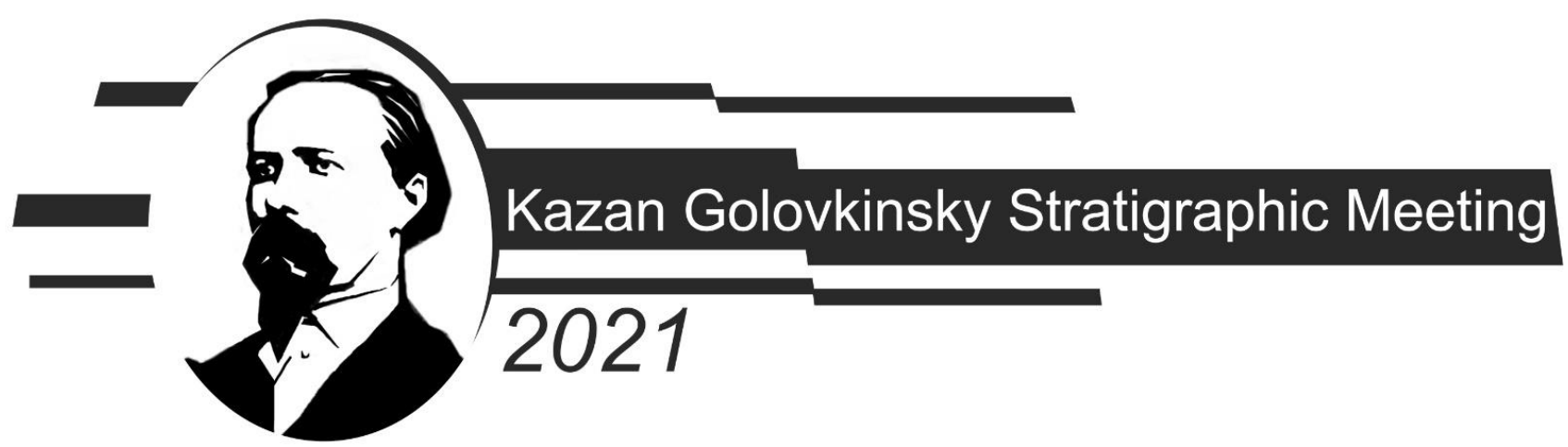

Kazan Golovkinsky Stratigraphic Meeting 2021, celebrating the 180th anniversary of the establishment of the Permian system

Sedimentary Earth Systems: Stratigraphy, Paleoclimate, Geochronology, Petroleum Resources

Sixth All-Russian Conference "Upper Paleozoic of Russia"

October 18-22, 2021, Kazan, Russia

\section{Abstract Volume}

Editor-in-Chief:

Danis K. Nurgaliev

Scientific editor:

Vladimir V. Silantiev

Technical editors:

Milyausha N. Urazaeva,

Veronika V. Zharinova 


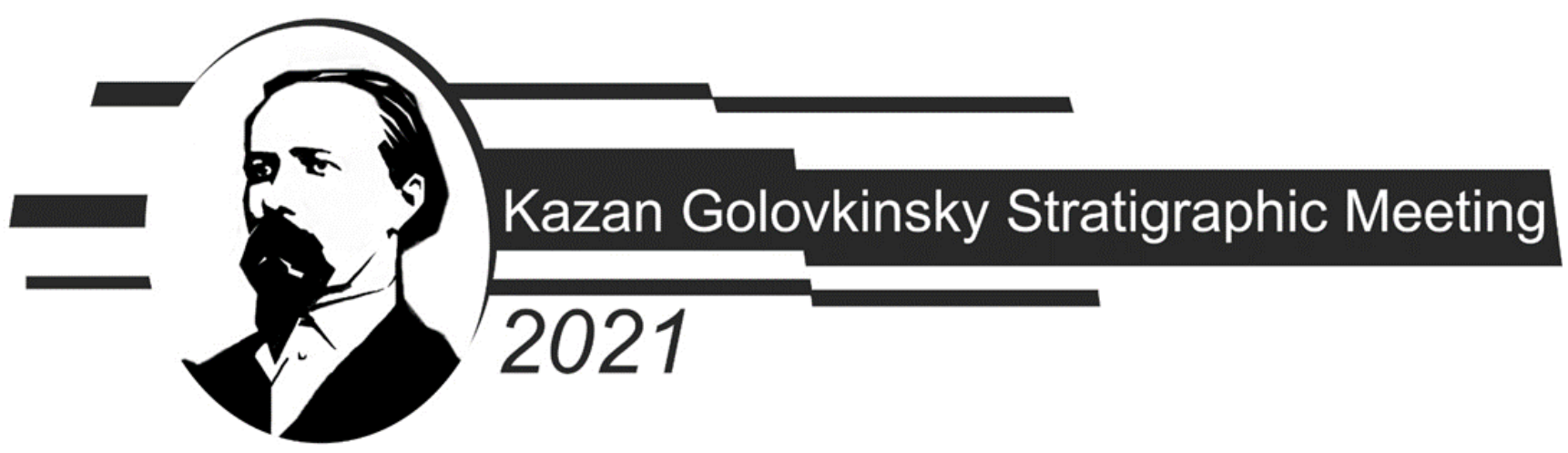

\section{Международная конференция \\ Kazan Golovkinsky Stratigraphic Meeting 2021,}

посвященная 180-летию со дня установления пермской системы

Осадочные системы: стратиграфия, геохронология, палеоклимат, углеводородные ресурсы

\section{Шестая Всероссийская конференция «Верхний палеозой России»}

18-22 октября 2021, Казань, Россия

\section{Сборник тезисов}

Ответственный редактор:

Данис К. Нургалиев

Научный редактор:

Владимир В. Силантьев

Технические редакторы:

Миляуша Н. Уразаева,

Вероника В. Жаринова 
Удк 55

ББК 26.3

K26

\author{
Editor-in-Chief \\ Danis K. Nurgaliev \\ Scientific editor \\ Vladimir V. Silantiev \\ Technical editors: \\ Milyausha N. Urazaeva, \\ Veronika V. Zharinova \\ Ответственный редактор \\ Данис К. Нургалиев \\ Научный редактор \\ Владимир В. Силантьев \\ Технические редакторы: \\ Миляуша Н. Уразаева, \\ Вероника В. Жаринова
}

Kazan Golovkinsky Stratigraphic Meeting 2021, celebrating the 180th anniversary of the

K26 establishment of the Permian system. Sedimentary Earth Systems: Stratigraphy, Paleoclimate, Geochronology, Petroleum Resources. The Sixth All-Russian Conference "Upper Paleozoic of Russia" (October 18-22, 2021, Kazan, Russia) [Electronic resource]: collection of abstracts. Electronic network data (1 file: $3.65 \mathrm{MB}$ ). - Kazan: Publishing House of Kazan University, 2021. 96 p. - System requirements: Adobe Acrobat Reader. - Access mode: http:// - Title from the title screen.

Международная конференция Kazan Golovkinsky Stratigraphic Meeting 2021, посвященная 180-летию со дня установления пермской системы. Осадочные системы: стратиграфия, геохронология, палеоклимат, углеводородные ресурсы. Шестая Всероссийская конференция «Верхний палеозой России» (18-22 октября 2021 г., Казань, Россия) [Электронный ресурс]: сборник тезисов. - Электронные сетевые данные (1 файл: 3,65 МБ). - Казань: Издательство Казанского университета, 2021. - 96 с. - Системные требования: Adobe Acrobat Reader. Режим доступа: http://. - Загл. с титул. экрана.

\title{
DOI
}

International Stratigraphic Meeting is dedicated Earth systems, stratigraphic events, paleoclimate, biotic evolution, sedimentary basins and resources.

Международная конфреренция посвящена проблемам планетарных систем, стратиграфическим событиям, палеоклимату, эволюции биоты, седиментационным бассейнам и полезным ископаемым. 


\section{Content}

Afanasieva Marina S., Ludmila I. Kononova

Early Tournaisian radiolarians and conodonts of the Volga-Ural Basin (Melekesskaya Borehole-1)

Afanasieva Nadezhda I., Svetlana O. Zorina, Konstantin I. Nikashin, 12 Mikhail Yu. Sokerin, Nadia Hamada

Paleogene sand injectites of the Uljanovsk-Syzran Volga Region (eastern part of the Russian Platform)

Bakaev Aleksandr S., Ilja Kogan

Scale morphology and histology of Discordichthyiformes A. Minich, 1998 (Osteichthyes)

Beznosova Tatyana M., Vladimir A. Matveev

Regional event scale of the Silurian (western slope of the Subpolar Urals and Chernov Swell)

\section{Bukhman Nikolay S., Lyubov M. Bukhman}

On the foliage of psygmophylloids from the Novyi Kuvak (Middle Permian, VolgaUral Region)

Bukhman Nikolay S., Lyubov M. Bukhman

On the representatives of the genus Biarmopteris from the Novyi Kuvak (Middle Permian, Volga-Ural Region)

\section{Dubkova Kseniya A., Sergey B. Shishlov, Eleonora M. Bugrova, Elena Yu. Zakrevskaya}

Composition, structure and formation history of the Lower Cretaceous - Eocene Section near the Mazanka Village (Central Crimea)

Goreva Natalia V.

Conodonts and the lower Kasimovian boundary in the Moscow Basin (Russia)

Gorozhanin Valery M., Nuriya S. Sagdeeva

Genesis of the stromatactis and zebra structure in the Famen carbonate deposits of the Orenburg arch-shaped uplift

Gorozhanina Elena N., Elena Yu. Bashlykova, Elena I. Kulagina

The microfacies of the Tulian Horizon (Visean, Lower Carboniferous) of the Sikaza Section, Southern Urals

Grunt Tatjana A.

Permian Kapp Starostin Formation (Spitsbergen): unresolved issues of age and correlation

Ivanov Alexander $\mathbf{O}$.

Chondrichthyan assemblages from the Middle - Upper Devonian of the Middle Urals, Russia 
Karimov Karim M., Akhmad Allali, Timur A. Vagapov, Marat A. Lonshakov

Results of space remote sensing when searching for hydrocarbon deposits in the Republic of Cameroon

Kogan Ilja, Elias Schlesiger, Jan Fischer

Elasmobranch vertebrae from the Late Cretaceous of Saxony (Germany)

Kuzina Dilyara M., Anastasia R. Yusupova, Kirill A. Voronov, Vadim V. Antonenko

Magnetic investigations of Lake Bannoe (South Urals) sediments

Leonova Lubov' V., Elena I. Soroka, Natalia P. Safina, Akhmet A. Galeev

Traces of microbial activity in the sediments of near-bottom hydrothermal facies in pyrite deposits of the Urals

Leonova Tatiana B.

Permian ammonoids: results and prospects of Russian paleontologists's research

Makoshin Victor I., Ruslan V. Kutygin

Terminal Carboniferous of the lower reaches of the Lena River (Northern Verkhoyanie, North-East of Russia): brachiopods and biostratigraphy

Maksimov Gleb S., Igor A. Nauhatsky

Mineral composition of the Saki mud

Malysheva Elena, Maria Doronina, Ludmila Kleschina, Vera Nikitina, Andrey Popov, Natalya Vasilyeva

The Permian-Triassic boundary in the Barents Sea

Miftakhutdinova Dinara N., Ruslan V. Kutygin

The Permian-Triassic trace fossils of the Southern Verkhoyansk Region (TiryakhKobyume Section, Sakha-Yakutia)

Miftakhutdinova Dinara N., Vladimir V. Silantiev, Nuriia G. Nurgalieva, Ilja Kogan, Rishat M. Habipov, Kirill D. Shumatbaev, Vladislav A. Sudakov, Marat F. Validov

Ichnofacial analysis of the Pashyian and Timanian Regional Stages (Devonian) of the Southern Tatarian Dome (East European Platform)

Mohammad Nosheen, Nouria G. Nourgalieva

Lithofacies and sequence stratigraphy interpretation of the Pokurskaya Formation in the Cenomanian Succession, north of the West Siberian Basin

Morkovin Boris I., Justyna Slowiak, Andrey V. Podlesnov, Igor V. Morkovin

New localities of the Early Triassic terrestrial vertebrates of the upper part of Luza River (Komi Republic, Russia)

Mouraviev Fedor A., Vladimir V. Silantiev, Tatiana V. Kropotova

Paleosols from the Upper Kazanian red beds of Sentyak section: preliminary results

Naugolnykh Serge V., Olga A. Kokina

A fertile branch of Lepidodendron obovatum Sternberg from the Lower Carboniferous (Visean) deposits of the Kaluga region, Russia 
Naumcheva Maria A.

Evidence of sex dimorphism in smooth Permian ostracods

Nigamatzyanova Gulnara R., Niyaz M. Nigmatullin, Irina V. Fedorova, Larisa A. Frolova

Paleovegetation reconstruction for the central part of Yamal Peninsula based on the pollen analysis from the Lake Neyto-Malto sediments

Nigamatzyanova Gulnara R., Vera D. Strakhovenko, Larisa A. Frolova

Subrecent spore-pollen spectra from Lake Onego (the European part of Russia)

Nigmatullin Niyaz, Alekasand Eliseev, Larisa Frolova

Assessment of microcrustacean (Crustacea, Cladocera) biodiversity based on surface sediment samples from the northern lake Neito-3 (Malto) (YamaloNenets Autonomous Okrug, Russia)

Nigmatullin Niyaz M., Gulnara R. Nigamatzyanova, Elvira A. Valieva, Larisa A. Frolova

The microcrustacean biodiversity in the lakes of the Pechora River Delta based on the analysis of subfossil Cladocera

Nikashin Konstantin I., Svetlana O. Zorina

The sources of terrigenous and volcanic ash material in the Middle Volgian (Jurassic) deposits of the eastern part of the Russian Platform

Porokhovnichenko Lyubov G., Ruslan V. Kutygin, Afanasiy N. Kilyasov

About the age of the Kygyltasian fossil flora from the Upper Paleozoic of Verkhoyanie, North-Eastern Russia

Rakhimov Ildar R.

Chromite sandy sediments Kazanian Permian the Southern Pre-Urals

Ryabinkina Nadezhda N., Olga S. Kotik, Olga V. Valyaeva, Sergey V. Ryabinkin

Permian coal formation of the Pechora basin

Ryabinkina Nadezhda N., Olga V. Valyaeva, Sergey V. Ryabinkin

Geology and geochemistry of organic matter of the Lower Carboniferous deposits of the north of the Kolva of the Timan-Pechora province

\section{Scholze Frank}

Sedimentary structures from the Early Permian Tambach Sandstone at the Bromacker (Thuringian Forest basin, Germany)

Shaidullin Rustam R.

Designing the development of productive deposits of a gas condensate field with a complex geological structure

Shchedukhin Alexander Yu.

New non-ammonoid cephalopods of the Early Permian Shakh-Tau reef 
Silantiev Vladimir V., Dinara N. Miftakhutdinova, Veronika V. Zharinova, Milyausha N. Urazaeva

Evidence for soft-bodied organisms and invertebrate soft tissues in mudstones of the Timanian Horizon (Devonian, Frasnian) of the Southern Tatarian Dome (East European Platform)

Silantiev Vladimir V., Andrey G. Sennikov, Valery K. Golubev, Joerg W. Schneider

Outline of the history of the Permian System in Russia and Central Europe

Silantiev Vladimir V., Milyausha N. Urazaeva, Ilja Kogan

on-marine bivalves from the volcanic succession of the Siberian Flood-Basalt Province

Sitnov Sergey S., Albert F. Shageev, Emil R. Baigildin, Alexey V. Vakhin, Danis K. Nurgaliev

Increasing the efficiency of hard-to-recover oil production from a carbonate reservoir using thermochemical method

Tagarieva Rezeda Ch.

The Makarovo Horizon (Famennian, western South Urals) in the regional scale of Devonian, correlation with the global standard

Timonina Natalia $\mathbf{N}$.

Lithological and geochemical peculiarities of the Lower Triassic sandstones in the northern regions of the Timan-Pechora oil and gas-bearing province

Yusupova Anastasia R., Nuriia G. Nourgalieva, Dilyara M. Kuzina, Lina R. Kosareva, Pavel S. Krylov, Vadim V. Antonenko

Lacustrine sediments variability on magnetic properties, mineral and chemical composition, lakes Bolshoye Miassovo and Turgoyak (South Urals)

Zharinova Veronika V.

Beds with conchostracans at the Upper Permian and Lower Triassic of Eastern Europe and Siberia

Zhuravlev Andrey V., Denis A. Gruzdev, Yadviga A. Vevel,
Andrey V. Erofeevsky 69 Andrey V. Erofeevsky

Mid-Famennian negative C-isotope excursion in the Izyayu River section (Tchernyshev Uplift, Pechora Plate)

Zorina Svetlana 0.

Unfavorable habitat for benthic foraminifers during the Late Jurassic OAE and Early Aptian OAE 1a in the epeiric sea of the eastern part of the Russian Platform

Акишина О.В.

Миоспорты и криптоспоры из визейских отложений Волго-Уральской области

Бакаев А.С., Буланов В.В., Илалтдинов И.Я., Кожанов Д.Д., 72 Пономарева Г.Ю., Хопта И.С.

О возрастном положении разреза Куеда-Ключики - уникального местонахождения позвоночных средней перми (Пермский край) 
Бяков А.C.

Иноцерамоподобные двустворчатые моллюски и великое позднепермское вымирание на Северо-Востоке Азии

Брынько И.В., Бяков А.С., Ведерников И.Л.

Изотопные исследования углерода пермских известняков юго-восточной части Омолонского массива

Воронков C.E.

Поиск перспективных на углеводороды объектов на основе геологогеофизических данных в отложениях саргаевского горизонта на северовостоке Республики Татарстан

Зуб О.H.

Перспективы нефтегазоносности юго-западной части Краснодарского края по результатам гидрохимических исследований пластовых вод ЗападноКубанского и Керченско-Таманского прогибов

Котик О.С., Салдин В.А.

Органическое вещество, его генерационный потенциал и состав артинских отложений севера Предуральского краевого прогиба (Тимано-Печорская провинция)

Минина О.P.

Поздний палеозой Бамбуйско-Олингдинской синформы Западного Забайкалья

Мударисова Р.А., Фахрутдинов И.Р., Фахрутдинов Э.И.

Влияние вторичных процессов на коллекторские свойства карбонатных пород казанского яруса на примере Мелекесской впадины

Пономарева Г.Ю.

Граница серпуховского и башкирского ярусов в разрезах Губахи (Средний Урал, Пермский край)

Раскатова М.Г. Юрина А.Л.

Миоспоры из нижнефранских отложений чаплыгинской свиты Воронежской антеклизы

Сенников А.Г.

Экспедиция Р.И. Мурчисона в г. Вязники и установление пермской системы

Сначев А.B.

Геология углеродистых отложений Сухарышской синклинали (Южный Урал)

Сонин Г.В., Коссовая О.Л., Дитер Вейер, Сонина О.Г.

Байтуган, Камышла и Бузбаш - разрезы казанского яруса на р. Сок Самарской области

Сунгатуллина Г.М., Сунгатуллин Р.X., Буслаев Р.В.

Новые геохимические данные для приграничного интервала касимовского и гжельского ярусов в разрезе Усолка, Южный Урал 
Сысоева A.O.

Новый взгляд на геологическое строение района междуречья рек Ассель и Ускалык Южного Предуралья

Тарасенко А.Б., Матвеев В.П., Норова Л.П., Цинкобурова М.Г.

Особенности выделения местных стратиграфических подразделений нижнего франа Главного девонского поля

Тюрин А.М., Коломоец А.В., Сначёв А.В., Смолева И.В., Панкратьев П.В.

Углеродистые формации Магнитогорского прогиба (Южный Урал) и перспективы их нефтегазоносности

Фетисова А.М., Веселовский Р.В., Голубев В.К.

Палеомагнетизм пограничных пермо-триасовых осадочных пород Оренбургской области

Фетисова А.М., Голубев В.К., Веселовский Р.В., Балабанов Ю.П., 94 Наумчева М.A.

Магнитостратиграфическая шкала пограничных отложений перми и триаса Восточно-Европейской платфрормы

Чистякова А.В., Веселовский Р.В., Ковач В.П., Марфин А.Е., Фетисова А.М., Голованова Т.И.

Детритовая геохронология циркона пограничных пермь-триасовых отложений разреза Боевая Гора (Оренбургская область) 


\title{
Early Tournaisian radiolarians and conodonts of the Volga-Ural Basin (Melekesskaya Borehole-1)
}

\author{
Marina S. Afanasieva ${ }^{1}$, Ludmila I. Kononova² \\ 1Borissiak Paleontological Institute, Russian Academy of Sciences, Moscow, Russia; afanasieva@paleo.ru \\ ${ }^{2}$ Lomonosov Moscow State University, Moscow, Russia
}

Until now, definite and well-preserved Early Tournaisian radiolarians have not been known in Northern Eurasia. The only Entactiniidae gen. et sp. indet. assemblage established previously in the Peri-Caspian Basin was so taxonomically poor that it cannot be used for biostratigraphic purposes. However, the common presence of spherical radiolarians made it possible to establish beds with Entactiniidae gen. et sp. indet. (Afanasieva, 1987, 2000), but this extremely depleted (reliably known in Northern Eurasia) Early Tournaisian radiolarian assemblage (ecozone) was included in the International Catalogue of Paleozoic radiolarian genera (Aitchison et al., 2017).

At present, well preserved radiolarians are found for the first time in six samples from the basal Lower Tournaisian sediments of the Volga-Ural Basin (Melekesskaya Borehole-1). Radiolarians are represented by 25 species of nine genera. At the same time, some of the radiolarian species are not known to science and characterized only for the Lower Tournaisian.

Conodonts are found only in 15 samples (out of 57 selected samples) of the Tournaisian deposits of the Melekesskaya Borehole-1 from depths of 1690.0-1898.5 m. They are represented by single specimens of the genera Siphonodella, Bispathodus, Neopolygnathus, Polygnathus. However, considering the poor content of conodonts, it is possible only conditionally to identify only a few beds with conodonts. The zonal conodont Siphonodella duplicata was found together with radiolarians in three samples from depths of 1881.7-1883.8 $\mathrm{m}$.

The rich taxonomic composition and excellent preservation of the radiolarians make it possible to establish two radiolarian ecozones in the Lower Tournaisian deposits of the Melekesskaya Borehole-1 from depths of 1881.7-1894.30 m.

The Lower Ecozone is represented by 18 radiolarian species of six genera. The biostratigraphic position of the Lower Ecozone corresponds to the $S$. duplicata conodont Zone. The Upper Ecozone includes 13 species of six genera. The biostratigraphic position of this Ecozone conditionally corresponds to the $S$. belkai-S. quadruplicata conodont zones.

An inversion of the taxonomic diversity of the representatives of Sphaerellaria and Spumellaria can be seen in the Lower and Upper ecozones. That is, whereas porous Sphaerellaria dominate $(57.9 \%)$ in the Lower Ecozone, the opposite ratio of morphotypes is seen in the upper part of the borehole section. Spongy-reticular Spumellaria (53.8\%) are dominant in the Upper Ecozone. 


\title{
Paleogene sand injectites of the Uljanovsk-Syzran Volga Region (eastern part of the Russian Platform)
}

\author{
Nadezhda I. Afanasieva ${ }^{1}$, Svetlana O. Zorina ${ }^{1}$, Konstantin I. Nikashin ${ }^{1}$, Mikhail Yu. \\ Sokerin ${ }^{2}$, Nadia Hamada ${ }^{1}$ \\ ${ }^{1}$ Kazan Federal University, Kazan, Russia; svzorina@yandex.ru \\ ${ }^{2}$ Institute of Geology named after academician N.P. Yushkin FRC of Komi SC, Ural Branch of RAS, \\ Syktyvkar, Russia
}

The Paleogene quartz sandstones of the Sosnov Formation that occurred in the UlyanovskSyzran Volga region of the eastern part of the Russian Platform have been actively developing for a long time as they are known as a valuable source of industrial minerals, of which glass raw materials are of particular value. The latter is considered a scarce raw material of Federal significance, consumption of which increases annually. But, predicting new deposits based on ideas on the coastal-marine origin of the Sosnov sandstones exhausted possibilities. Thus, the research aim is to consider the Sosnov Formation from a new perspective of sand intrusions.

Modeling the sand intrusion mechanism of deposition of the Sosnov Formation has been carried out. The Sosnov quartz sandstones could be formed due to the penetration of free silica into the loose sands, released during the diagenesis of the volcanic ash material. The postThanetian age of the Sosnov Formation is possible. The necessity of a new scientific basis for forecasting and prospecting works on mineral raw materials associated with Sosnov sands and sandstones, based on new ideas about their genesis, is shown. That could improve the accuracy of predictive constructions and remove restrictions on the mineral resource base of glass and construction sand raw materials in the region.

A new glance at the nature of the Sosnov Formation of the Ulyanovsk-Syzran Volga region is applied to the Eocene Buchak sandstones that occurred in the Voronezh Anticline. The result is planning to be included in the Event stratigraphic scheme of the Paleogene for both regions. So, the Paleogene geologic history of the eastern and southern parts of the Russian Platform, usually associated with the evolution of the shallow sea basin, could be supplemented by new data on sand intrusions, which influenced the accumulation of sediments in the Paleogene. 


\title{
Scale morphology and histology of Discordichthyiformes A. Minich, 1998 (Osteichthyes)
}

\author{
Aleksandr S. Bakaev ${ }^{1}$, Ilja Kogan²,3 \\ ${ }^{1}$ Borissiak Paleontological Institute, Moscow, Russia; alexandr.bakaev.1992@mail.ru \\ ${ }^{2}$ TU Bergakademie Freiberg, Geological Institute, Freiberg, Germany; i.kogan@gmx.de \\ ${ }^{3}$ Kazan Federal University, Kazan, Russia
}

Discordichthyiformes A. Minich, 1998, are enigmatic fishes endemic to the Middle and Late Permian of European Russia. They show similarities to actinopterygians in the structure of skull and squamation, but differ from these in possessing two dorsal fins with leading spines as well as pectoral fins with spines; meanwhile, there is no evidence of bony lepidotrichia as in other osteichthyans. Six taxa have been described based on fragmentary remains, while, only one species (Mamulichthys ignotus A. Minich, 2014) is known by a reasonably complete skeleton. We present the first detailed micromorphological and histological data on the squamation of these puzzling animals.

Flank scales of discordichthyiforms are high, rectangular, thin, with straight margins, lacking a pronounced anterodorsal corner. Both posterior corners are right. The peg is triangular, flat, very wide, often spanning the whole scale length at its base, often bearing vertical furrows. The socket is also wide and long, usually up to half the height of the scale. Some pores are scattered posterior to the indistinct keel.

The sculptureless depressed field makes up $1 / 3-1 / 4$ of the scale length. The free field is ornamented by prominent, ovoid, relatively closely spaced odontodes of two principal types: large stellar tubercles with a pointed tip and well-developed crests, thinning away towards the base (characteristic for Mutovinia and Mamulichthys) and tubercles of various, mainly ovoid shape, in the remaining forms. A transition between these two types has not been observed. The odontodes sometimes bear denticles, sitting free (Discordichthys) or on the vertical crests (Mutovinia and Mamulichthys).

Ridge scales are triangular, with a narrow depressed field and an ornamentation similar to the flank scales, except for larger odontodes on the posterior margin forming a prominent denticulation.

A hypermineralized layer on the odontode surface is lacking, as is any kind of ultrasculpture. Histologically, the scales consist only of the dentine odontodes and lamellar cellular bone underlying forming the base. The odontodes are set off from one another, are seprated by bone, and have a mushroom-shaped profile with a broad upper part and a narrow base bearing the pulp cavity, which is continues to the opening of the pulpal canal enclosed into concentric dentine layers. Short pore canals radiate from the pulpal canal and open in pores around the odontode base. The canals connect to vascular canals in the upper bone layer. The bone layer is thick and contains large osteocyte lacunae in its upper part. Numerous Sharpe's fibres pierce it irregularly.

The unusual morphology and histology of discordichthyiform scales is clearly distinct from the rhombic scales of Palaeozoic actinopterygians and sarcopterygians, but shows similarities to stem bony fishes such as the Late Silurian Lophosteus. 


\section{Regional event scale of the Silurian (western slope of the Subpolar Urals and Chernov Swell)}

Tatyana M. Beznosova, Vladimir A. Matveev

N.P. Yushkin Institute of Geology, Komi Scientific Centre, Ural Branch, Russian Academy of Science, Syktyvkar, Russia; beznosova@geo.komisc.ru

The developed regional event-stratigraphic scale of the Silurian is based on the study of reference sections located in the Subpolar Urals and the Chernov Swell.These sections, in which traces of the global events have been preserved, are typical for the unified Silurian subdivisions of the West Ural subregion. Brachiopods, conodonts, ostracods, and corals define the age of the intervals of the sections in which traces of the global events are found.

The distinguished traces of regional events are considered in close context with the main global isotopic, eustatic and biotic events in the Silurian - Late Aeronian/Sandvika Event, Early Wenlock Ireviken Event, Late Wenlock Event, Late Ludfordian Event/Lau, and Early Pridolian/Klev Event. The event levels are substantiated by characteristic changes in the composition of biotas, sedimentation conditions, and in organic carbon isotopic data. On the global isotope curve all the Silurian events are characterized by positive shifts of $\delta^{13} \mathrm{C}$. On the regional isotope curve, the positive shift of $\delta^{13} \mathrm{C}$ is most clearly expressed, marking the Klev Event in the sections of the Upper Silurian, that correlates with the Early Pridolian transgression (Beznosova et al., 2020). The intervals of the sections in which traces of the Lau, Mulde, Ireviken, and Sandvika events were found are characterized by distinct sedimentation signs of shallowing of the North Ural Basin: the development of stromatolite-forming biota, interlayers with flat-pebble conglomerates, surfaces of breaks in sedimentation and extinction of benthic fauna (Matveev at el,. 2020).

The absence of other pronounced positive shifts in $\delta^{13} \mathrm{C}$ on the regional isotope curve is probably cansed by the fact that the event intervals were destroyed as a result of gaps in sedimentation due to not only eustatic processes, but also regional tectonic events.

The studies carried out have shown the possibility of a global correlation of the studied sections through comparison with sections from other regions, in which the relationships of carbonate rocks with fauna and shale rocks enclosing graptolites have been established.

The identified event-stratigraphic correlation levels, which are determined by biotic, sedimentological, eustatic and isotopic data, make it possible to compensate for the shortcomings of the biostratigraphic method associated with the ecological control of the distribution of organisms. 


\section{On the foliage of psygmophylloids from the Novyi Kuvak (Middle Permian, Volga-Ural Region)}

Nikolay S. Bukhman, Lyubov M. Bukhman

Samara State Technical University, Samara, Russia; nik3142@yandex.ru

Novyi Kuvak is one of the locations in the Volga-Uralian Region where Middle Permian (Kazanian) flora can be found. Geographically, this location is positioned in the extreme North-East of the Samara region, close to the border with Tatarstan.

Most commonly found at this location are imprints of Cordaites foliage (Rufloria sp.). The next most frequently occurring imprints are those of the vegetative organs of plants from the Sphenophyta (Paracalamites sp.), Ginkgophyta and Peltaspermaceae.

The fossil plants are found at the Novyi Kuvak site consist of calcareous fine-grained sandstone. As a result of this epidermal-cuticular analysis of the fossils is impossible. A microscopic examination of the surface of the bedding planes also turned out to be unsuccessful, primarily because when using a microscope, an increase in the magnification of the image results in a decrease of its depth of field, thus making it impossible to accurately display something with an uneven surface. So the main method of studying the samples is through an examination of their photographs.

Some preliminary results of studying the foliage of psygmophylloids from this location are presented. We are found, in particular, representatives of the genus Psygmophyllum Shimper, 1870, emend Saporta, 1878 (Psygmophyllum expansum var. expansum Naug., 2002; Psygmophyllum expansum var. cuneatum Naug., 2002; Psygmophyllum cuneifolium (Kutorga) Shimper; Psygmophyllum sp. nov.,), Bardia Zalessky, 1933, Angaridium (Schmalhausen) Zalessky, 1933 (Angaridium potanini Zalessky, 1933), Mauerites Zalessky, 1933, Kerpia Naugolnykh, 1995 (Kerpia samarica N.S. Bukhman et L.M. Bukhman, 2014), Glossopteropsis Zalessky, 1918 (Glossopteropsis angarica Zalessky, 1918), Rhipidopsis Schmalhausen, 1879, Rhaphidopteris Barale, 1972, Flabellofolium Stone, 1973, as well as unidentified cladosperms, probably belonging to psygmophylloids. 


\title{
On the representatives of the genus Biarmopteris from the Novyi Kuvak (Middle Permian, Volga-Ural Region)
}

\author{
Nikolay S. Bukhman, Lyubov M. Bukhman \\ Samara State Technical University, Samara, Russia; nik3142@yandex.ru
}

Novyi Kuvak is one of the locations in the Volga-Uralian Region where Middle Permian (Kazanian) flora can be found. Geographically, this location is positioned in the extreme North-East of the Samara region, close to the border with Tatarstan.

Most commonly found at this location are imprints of Cordaites foliage (Rufloria sp.). The next most frequently occurring imprints are those of the vegetative organs of plants from the Sphenophyta (Paracalamites sp.), Ginkgophyta and Peltaspermaceae.

The fossil plants are found at the Novyi Kuvak site consist of calcareous fine-grained sandstone. As a result of this epidermal-cuticular analysis of the fossils is impossible. A microscopic examination of the surface of the bedding planes also turned out to be unsuccessful, primarily because when using a microscope, an increase in the magnification of the image results in a decrease of its depth of field, thus making it impossible to accurately display something with an uneven surface. So the main method of studying the samples is through an examination of their photographs.

Some preliminary results of the study of representatives of the genus Biarmopteris Zalessky, 1937 from the location of the Novyi Kuvak (Middle Perm, Southern Urals) are presented. Prints of Biarmopteris sp. are found in connection with the stem, which is in association with the Kerpia sp. foliage. A radiospermical seed are found, presumably belonging to the cladosperm Biarmopteris sp.

Basically, the prints identified as Biarmopteris sp. are in association with the foliage of Cordaitales, which is probably due simply to the abundance of this foliage in the New Kuvak. More interesting is the detection of Biarmopteris sp. in an organic connection with the stem, which in turn is in association with a leaf that can probably be attributed to the genus Kerpia Naugolnykh, 1995.

The main conclusion of the conducted review is the conclusion about the non-monotypic nature of the genus Biarmopteris Zalessky or, possibly, about a significant proportion of aberrant specimens of this genus in the location of Novyi Kuvak. The discovery of a seed presumably belonging to this genus is also of interest. 


\title{
Composition, structure and formation history of the Lower Cretaceous - Eocene Section near the Mazanka Village (Central Crimea)
}

\author{
Kseniya A. Dubkova ${ }^{1}$, Sergey B. Shishlov ${ }^{1}$, Eleonora M. Bugrova ${ }^{2}$, Elena Yu. \\ Zakrevskaya $^{3}$ \\ ${ }^{1}$ St. Petersburg State University,St. Petersburg, Russia; ksenya-dubkova@mail.ru \\ ${ }^{2}$ A.P. Karpinsky Russian Geological Research Institute, St. Petersburg, Russia \\ ${ }^{3}$ Vernadsky State Geological Museum of the Russian Academy of Sciences, Moscow, Russia
}

For the first time, the article provides a detailed description of the $25 \mathrm{~m}$ thick Mazanka village Cretaceous-Eocene section, and its stratigraphic subdivision. Comparison with the outcrops of the Zuya quarry and the Bodrak river basin, facies analysis and reconstruction of sedimentation environments have been carried out to clarify the geological history of the Simferopol uplift.

It is shown that, in the Valanginian-Early Hauterivian, silty and sandy deltaic deposits of the sedimentation regressive phase were concordantly overlapped by a transgressive sequence, formed (from bottom to top) by coastal shallows sandy and conglomerate sediments, interlayering middle ramp clayey silts and sands, and outer ramp clay. Localized above unconformity is not presented by rock for at least $70 \mathrm{Ma}$ interval, from the Early Hauterivian to the Late Ypresian. The Upper Ypresian sediments, dated by foraminifera, overlap with ravinement the Lower Hauterivian clays, altered by the processes of subaerial soil formation. The Ypresian lower part is formed by the transgressive lag fine-grained glauconite-quartz sandstones, accumulated near the coast. From this level, the complex of large benthic foraminifera, typical of the SBZ 10 (Upper Ypresian), was established. Sandy marls with boulders and pebbles of nummulitic limestones lies above, they were formed in a highly dynamic sea shallows environment. The topmost nummulitic limestones (floatstones) present accumulations of large bentic foraminifera's shells, moved to the shallows by sea waves.

We conclude that in the Late Ypresian nummulitic shoal did not form a barrier for waves, and was separated from the Simferopol island land by highly dynamic coastal shallows, completely flooded only at the end of the Ypresian. 


\title{
Conodonts and the lower Kasimovian boundary in the Moscow Basin (Russia)
}

\author{
Natalia V. Goreva
}

Geological Institute, Russian Academy of Sciences Moscow, Russia; n.v.goreva@mail.ru

The problems of definition and global correlation of the Moscovian/Kasimovian boundary is still uncertain and a biostratigraphic marker and GSSP for it have not yet been designated. Several conodont species are proposed and discussed of the Task Groupe to be a potential index for the boundary definition: (1) FAD Idiognthodus sagittlis Kozitskaya 1978 or I. turbatus Rosscow and Barrick 2009 (Villa and Task Group, 2008; Ueno and Task Group, 2017); (2) FAD I. heckeli as the level of the development of a complete, continuous eccentric groove in species of Idiognathodus was proposed by and S. Rosscoe and J. Barrick (2013); (3) FAD Swadelina subexcelsa Alekseev and Goreva 2001 (Makhlina et al., 2001; Sungatullina, Davydov, 2015; Sungatullina, 2017). This level is to retain the base of the Kasimovian near its traditional boundary at the base of the Krevyakinian Regional Substage in the Moscow Basin. Distribution of the potential conodont markers and clarifies the position of these levels will be done in the reference sections in the type area of the Kasimovian in the Moscow Basin - Afanasivo, Domodedovo, Turaevo (Myachkovo) sections and Perkhurovo well. At the type area of the base of the Krevyakinian Substage of the Kasimovian corresponding to a gap and a very prominent regression is marked by a significant renewal of the taxonomic composition of the conodont assemblage. It relates to a complete disappearance of the species of the genus Neognathodus and predominance of the genus Swadelina. Sw. subexcelsa appears and immediately becomes dominant from the base of the Suvorovo Fm, the lower formation of the Krevyakinian.

Idiogbathodus heckeli and I. turbatus in the Moscow Basin appear approximately at the middle of the Neverovo Fm. of the Khamovnikian Substage. The ICCS Task Group has agreed that the FAD of the conodont Idiognathodus heckeli (similar forms are I. turbatus and I. sagittalis) at the level close to the appearance of advanced fusulinid species of the genus Montiparus is a suitable marker for the boundary level definition, but in the type area of the Kasimovian Stage both events coincide with the middle of the Khamovnikian Substage, i.e. 1.5 substages higher than the traditional boundary of the Kasimovian Stage. Nevertheless, the presence of relatively numerous Id. heckeli and I. turbatus at the Moscow Basin and Oka-Tsna Swell suggests a wide geographical distribution for this species and the possibility of a more precise correlation Russian sections with sections of the US Midcontinent and South China, but this level does not define the boundary of the Kasimovian.

The traditional lower boundary of the Kasimovian in the type area coincides with a level of the appearance of the Swadelina subexcelsa. This species was identified also at the other regions (Fig.1): Volga region (Sungatulina, 2002), South Urals (Alekseev et al., 2002; Sungatulina, 2017), Donets Basin (Nemyrovska, 2017), South China (Hu, Qu, 2019). So, Sw. subexcelsa traced across large distances, including different countries and continents and could be regarded as a good marker for Moscovian/Kasimovian boundary, unfortunately, an ancestor for this species has not yet been identified. Swadelina einori (Hu, Qu 2017; Hu et al., 2019) or Idiognathodus podolskensis Goreva (Sungatullina, 2017) were proposed as probably ancestor to Sw. subexcelsa, but this proposition needs further study. 


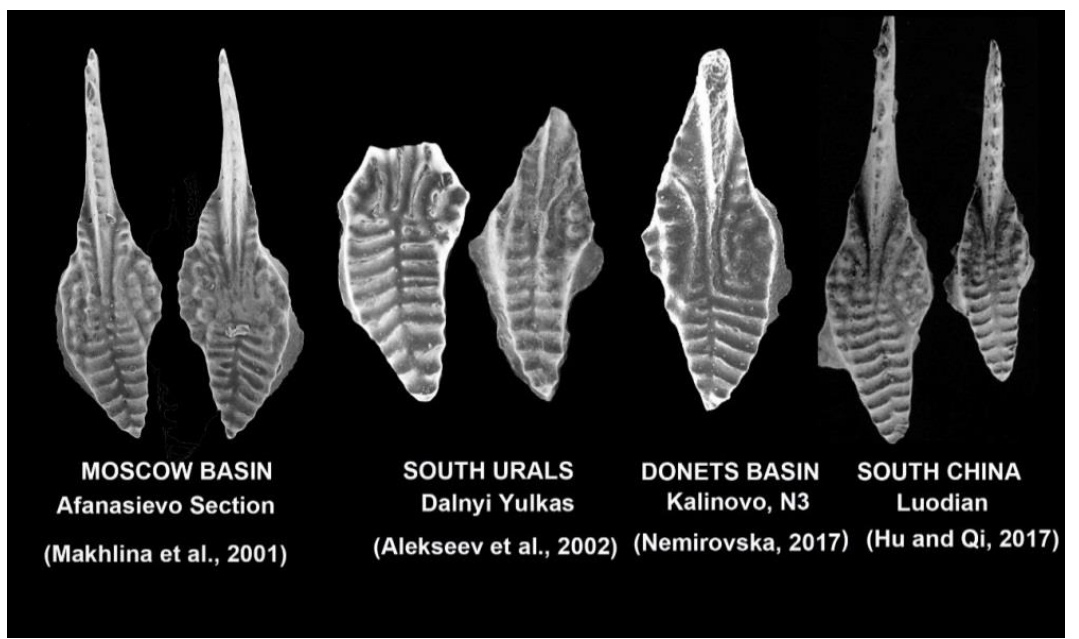

Fig.1. Swadelina subexcelsa Alekseev et Goreva 2001 from different regions.

\section{REFERENCES}

Alekseev A.S. Carboniferous of the South Urals / A.S. Alekseev, N.V. Goreva, E.I. Kulagina, O.L. Kossovaya, T.N. Isakova, A.N. Reimers // Fieldtrip of the Working Group to establish a GSSP in the upper part of the Carboniferous System (SCCS Project 5). Guidebook, August 10-18, Moscow and Ufa. $-92 \mathrm{p}$.

Hu K.Y. The Moscovian (Pennsylvanian) conodont genus Swadelina from Luodian, southern Guizhou, South China / K.Y. Hu, Y.P. Qi // Stratigraphy. - 2017. - V. 14. - P. 197-215.

Hu K.Y. Carboniferous conodont zonation of China / K.Y. Hu, Y.P. Qi, W.K. Qie, Q.L. Wang // Newsletters on Stratigraphy. - 2019. doi:10.1127/nos/2019/0498

Makhlina M. Middle Carboniferous of the Moscow Syneclise (southern part). Volume 2. Paleontological

Characteristics / M. Makhlina, A. Alekseev, N. Goreva, T. Isakova, O. Kossovaya, S. Lazarev, O. Lebedev, A. Shkolin Moscow: Nauchnyi Mir, 2001. - 328 p. (In Russian).

Nemyrovska T. Late Mississippian-Middle Pennsylvanian conodont zonation of Ukraine. In: Papers in celebration of H. Richard Lane / T. Nemyrovska // Stratigraphy. - 2017. - V. 14. - P. 299-318.

Rosscoe S., Barrick J. North American species of the conodont genus Idiognathodus from the Moscovian-Kasimovian boundary composite sequence and correlation of the MoscovianKasimovian stage boundary. In: The Carboniferous-Permian Transition / S.G. Lucas, W.A. Dimichelel, J.E. Barrick, J.W. Schneider, J.A. Spielmann eds. // New Mexico Museum of Natural History and Science Bulletin. - 2013. - V. 60. - P. 354-371.

Sungatulina G.M. Middle and Upper Carboniferous Conodonts of the Middle Volga Region and its

Stratigraphic Significance / G.M. Sungatullina // Extended Abstract of PhD Dissertation. Kazan, Kazan State University, 2002 (In Russian).

Sungatullina G.M. Kasimovian conodont of the Usolka section, South Urals / G.M. Sungatullina // Abstracts and papers of International Field Meeting of the I.U.G.S. Subcommission on Carboniferous Stratigraphy, Almaty-Turkestan. 2017. - P. 33-39 (In Russian).

Sungatullina G.M. New data on conodonts from the Kasimovian Stage of the Usolka section, southern Ural Mountains / G.M. Sungatullina, V.I. Davydov // Paleontological Journal. - 2015. - V. 49. - P. 1142-1149.

Ueno K., Task Group. Report of the task group to establish the Moscovian-Kasimovian and KasimovianGzhelian stage boundaries / K. Ueno // Newsletter on Carboniferous Stratigraphy. - 2017. - V. 33. - P. 18-20.

Villa E., Task Group. Progress report of the task group to establish the Moscovian-Kasimovian and Kasimovian-Gzhelian boundaries / E. Villa // Newsletter on Carboniferous Stratigraphy. - 2008. V. 26. - P. 12-13. 


\title{
Genesis of the stromatactis and zebra structure in the Famennian carbonate deposits of the Orenburg arch-shaped uplift
}

\author{
Valery M. Gorozhanin, Nuriya S. Sagdeeva \\ Institute of Geology - Subdivision of the Ufa Federal Research Centre of the Russian Academy of Sciences, \\ Ufa, Russia; sag-nyrija@mail.ru
}

Zebra textures and stromataceis are described in the core material of the Uranskaya area in the south-eastern part of the Orenburg arc-shaped uplift in the Famennian deposits; they are manifested in fenestral limestones of probable microbial genesis in the form of subhorizontal thin veins of zonal structure consisting of radially radiating UV-containing calcite. The total power reaches $10 \mathrm{~m}$ with rare small breaks. Alternating layers of dark microcrystalline limestone and layers of white calcite up to a centimeter thick form characteristic stripes in the rock, similar to the texture of a zebra. In accordance with the type of stromatactis, individual large voids in the fenestrel are also filled.

The genesis of the stromatactis structure is associated with various processes. The observations made on the stone material of the Uranskaya area allow us to clarify the genesis of these problematic formations. From our point of view, their formation is associated with synsedimentation deformations of layers consisting of fine-grained carbonate material of presumably microbial origin. Deformations of thin carbonate layers were probably possible if the carbonate sediment was held together by a flexible frame. Most likely, the puffs were bacterial mats consisting of calcium - fixing bacteria-calcimicrobes. The remains of calcimicrobes are observed microscopically. The empty space formed as a result of crumpling or tearing off the carpet was crystallized by hexagonal calcite. The same process took place in large fenestras. Due to the abundance of bacteria that make up the mat, the first generation of calcite captured organic matter during crystallization, resulting in its brownish-brown variety-calcite containing $\mathrm{HC}$, the second phase of the sixth calcite is formed by a white, inorganic variety.

Thus, puffs consisting of a pelitomorphic fine-grained carbonate material can be diagnosed as a bacterial mat, the carbonation of which occurred due to calcimicrobial bacteria.

In the Famennian deposits of the Uranskaya area, the entire complex of rocks stromatolites, oncolites, flat-stone breccias, fenestral limestones-indicates a tidal environment of carbonate shallow water. Thus, the genesis of the textures of stromatactis or zebra is interrelated with the microbial activity of bacterial mats, respectively, in the conditions of the tidal zone of shallow water. 


\section{The microfacies of the Tulian Horizon (Visean, Lower Carboniferous) of the Sikaza Section, Southern Urals}

Elena N. Gorozhanina, Elena Yu. Bashlykova, Elena I. Kulagina

Institute of geology, Ufa Federal Research Centre, Russian Academy of Sciences, Ufa, Russia; gorozhanin@ufaras.ru; duss 06@mail.ru; kulagina@ufaras.ru

The Carboniferous deposits of the "Sikaza» section in the west of the Southern Urals are of great geological significance and are included in the list of particularly significant objects of the Toratau geopark of the Republic of Bashkortostan. The purpose of this article is the lithofacial characterization of carbonate deposits of the Tula horizon of the Visean Stage in the section "Sikaza 2» near the Sikasya River. This article is based on samples from the collection of the Museum of Geology and Minerals of the Republic of Bashkortostan, Ufa. The main method used is the method of microfacial analysis of carbonate rocks in sections. During micro-description of limestone the classification after R. Dunham is used. Based on the study of textural and structural features and the composition of faunal remains in the Tula sediments of the "Sikaza» section, 5 microfacies ( $\mathrm{mf}$ ) of limestones formed under open shelf conditions were identified. A detailed description of them has been made.

Compiled from the materials after Z.A. Sinitsyna, I.I. Sinitsyn (1975), according to which the numbering of the layers is given. Sample numbers are based on stock reports.

Microfacies are:

1 - bioclast-crinoid packstones (mf1);

2 - bioclast-foraminiferous packstones (mf2);

3 - polybioclast packstones (mf3);

4 - peloid-foraminiferous grainstones ( $\mathrm{mf} 4$ );

5 - bioclast - foraminiferous grainstones ( $\mathrm{mf} 5$ ).

The sequence of microfacies indicates the alternation of sediments of currents and waves at the beginning of the Tula time and the gradual shallowing and formation of shallow shelf conditions towards its end. 


\title{
Permian Kapp Starostin Formation (Spitsbergen): unresolved issues of age and correlation
}

\author{
Tatjana A. Grunt \\ Laboratory-studio “Living Earth”, Moscow, Russia; t.grunt@mail.ru
}

The Kapp Starostin Formation (Fm.) is the uppermost stratigraphic unit of the Permian strata on Svalbard, whose age is still debatable. The Voringen Member (Mb.), up to $40 \mathrm{~m}$ thick, representing its lowermost subdivision, is firmly considered to be Late Artinskian-Early Kungurian based on the presence of a warm-water conodont assemblage discovered at its basal layers. This complex contains Sweetognathus whitei, marking the lower boundary of the Artinskian Stage, Neostreptognathodus pequopensis characteristic for its upper part; the appearance of $N$. pnevi corresponds to the lower boundary of the Kungurian Stage in the terms of International Standard (i.e., the base of the Sarana Horizon in the East European scale). The joint finding the indexspecies of three conodont zones indicates that this assemblage is most likely mixed and reworked. The boreal brachiopod assemblage from the Voringen Mb. includes about 30 species, some of which are of wide stratigraphic distribution, but some others definitely similar to the brachiopods from the Sabina Bay and Assistance Fm. in the Sverdrup Basin, as well as from the Mallemuk Mountain Group in NE Greenland.

The Sverdrup Basin biogeographically and territorially during the Permian period was very close to Spitsbergen. The Kungurian Trappers Cove Fm. containing N. pnevi, was separated from the overlying Sabine Bay Fm. by an interruption in sedimentation. The stratotype of Sabine Bay Fm. contains highly developed ammonoid genus Epijuresanites, indicates the most possible correlation to the Ufimian Stage in the terms of the East European scale. The Ufimian Stage corresponds to the uppermost part of the Kungurian of International Standard. The overlying Assistance Fm. containing characteristic Voringen brachiopods accompanied by the ammonoids Sverdrupites and Daubichites, indicating their affiliation to the Roadin (=Kazanian) Stage.

A comparative biostratigraphic review of some similar brachiopod assemblages yield a Late Kungurian (Ufimian) age for the Voringen Mb. instead of Late Artinskian-Kungurian based on conodont determinations. The Late Artinskian dating for the Voringen Mb. excluded.

The age of the upper part of the Kapp Starostin Fm. as indicated by conodonts is in great disparity with other fossils. Conodonts Mesogondolella idahoensis date the horizon in these layers as Late Kungurian. However, brachiopods Haydenella wilczeki and Pterospirifer alatus from the same layers (Hovtinden Mb.) suggest a robust correlation with the upper part of the Martinialimestone containing ammonoid Cyclolobus in East Greenland, marking the Wuchiapingian (=Dzoulfian) Stage. 


\title{
Chondrichthyan assemblages from the Middle - Upper Devonian of the Middle Urals, Russia
}

\author{
Alexander O. Ivanov ${ }^{1,2}$ \\ ${ }^{1}$ St. Petersburg State University, St. Petersburg, Russia; IvanovA-Paleo@yandex.ru \\ ${ }^{2}$ Kazan Federal University, Kremlovskaya St. 18, 420008 Kazan, Russia
}

The new assemblages of diverse chondricthyans occur in the Givetian - Famennian of six sections in the Middle Urals: Pokrovskoe, Baronskaya, Sulem, Pershino, and Yokva (Sverdlovsk Region), and Vilva (Perm Region).

The assemblage from the Upper varcus conodont zone $(\mathrm{CZ})$ of the Pokrovskoe section includes the teeth of Phoebodus fastigatus, Ph. sophiae. The fishes from the Upper disparilis CZ are represented by teeth of Phoebodus curvatus, Ph. fastigatus, Ph. sophiae and Ph. sp.; scales of "Ohiolepis", protacrodontid, ctenacanthid, and hybodontid types. The assemblage of the norrisi CZ contains the teeth of Phoebodus curvatus, Ph. fastigatus, Ph. latus and Ph. sp.; scales of "Ohiolepis", protacrodontid, ctenacanthid, and hybodontid types. The remains from the Upper falsiovalis CZ include the teeth of Phoebodus fastigatus, Ph. latus and Ph. sp.; scales of protacrodontid and ctenacanthid types.

The assemblage from the Frasnian Lower rhenana $\mathrm{CZ}$ of the Baronskaya section includes the teeth of Phoebodus bifurcatus, Ph. curvatus, Ph. fastigatus, Ph. latus, Ph. sp., Diademodus sp., and Protacodus sp.; scales of ctenacanthid type. The teeth of Phoebodus bifurcatus was found in the linguiformis CZ, as well as the tooth of Cladodoides sp. - in the Famennian Middle triangularis CZ.

The teeth of Phoebodus bifurcatus and Ph. latus occur in the Lower rhenana CZ of the Sulem section; the scales of ctenacanthid type - in the linguiformis CZ; teeth of Cladodoides sp. and cladodontomorph - in the Lower triangularis CZ; the teeth of Wellerodus sp. and Cladodoides $\mathrm{sp}$ - in the Upper triangularis CZ.

The tooth of Phoebodus curvatus is recorded in the Lower rhenana CZ of the Pershino section; the teeth of Protacodus sp. and scales of ctenacanthid type - in the Lower triangularis CZ; the teeth of Phoebodus typicus, Squatinactis sp., Protacodus sp., and Symmoriiformes indet.; scales of ctenacanthid and protacrodontid types - in the the Middle - Upper triangularis CZ.

The tooth of Phoebodus sp. occurs in the Frasnian Upper rhenana CZ the Yokva section; the teeth of Protacodus sp. - in the linguiformis CZ; the teeth of Thrinacodus ferox, Th. tranquillus, Squatinactis caudispinatus, scales of ctenacanthid type - in the Famennian postera - Middle expansa CZ interval; and the teeth of Thrinacodus ferox, Squatinactis caudispinatus - in the Middle expansa - Middle praesulcata CZ.

The diverse chondricthyans were recorded in the Upper Frasnian, Lower Famennian of the Vilva section. The remains from the Lower rhenana CZ includes the teeth of Phoebodus bifurcatus, Ph. curvatus, Ph. fastigatus, Ph. latus, Wellerodus sp., Diademodus sp., Protacodus sp., Protacrodontidae indet. and stethacanthid; scales of ctenacanthid type. The tooth of Protacodus sp., scales of ctenacanthid type occur in the Upper triangularis CZ. The fishes from the Lower crepida CZ include the scales of ctenacanthid and hybodontid types. The tooth of cf. Cladodoides sp. occurs in the Uppermost crepida CZ.

Diademodus and Wellerodus are reported in the Urals for the first time. The occurrence of Phoebodus species in the Pokrovskoe section allows to update the boundary between the Phoebodus sophiae and Ph. latus phoebodontid zones. Four phoebodontid zones, Ph. sophiae, Ph. latus, Ph. bifurcatus, and Ph. typicus, can be traced in the sections of the Middle Urals.

The work was supported by the Russian Foundation for Basic Research, project no. 20-05-00445a. 


\section{Results of space remote sensing when searching for hydrocarbon deposits in the Republic of Cameroon}

Karim M. Karimov, Akhmad Allali, Timur A. Vagapov, Marat A. Lonshakov Kazan Federal University, Kazan, Russia; maratlonsh@gmail.com

The goal of the research work is to evaluate geothermal factors for prediction of hydrocarbon deposits in the Republic of Cameroon using space remote thermovison sensing. Researches are based on the thermovision tomography of the Earth's crust by processing the spectral-zonal satellite images Terra-MODIS $и$ Landsat- 8 in the thermal infrared wavelength range. Results of image interpretation are used for mapping thermal field and block-fault structures to identify zones of fluid flows and accumulations which can be natural reservoirs of hydrocarbons.

Moreover, hypothesis of the formation of the Doula Basin are developed using complex data consisting of thermovision tomography images, well logs and seismic interpretation results. Additional tasks including the quality analysis of oil traps of some geological structures and identification of discontinuous faults are also solved. 


\title{
Elasmobranch vertebrae from the Late Cretaceous of Saxony (Germany)
}

\author{
Ilja Kogan ${ }^{1,2}$, Elias Schlesiger ${ }^{1,3}$, Jan Fischer ${ }^{4}$ \\ ${ }^{1}$ TU Bergakademie Freiberg, Geological Institute, Freiberg, Germany; i.kogan@gmx.de \\ ${ }^{2}$ Kazan Federal University, Kazan, Russia \\ ${ }^{3}$ TU Clausthal, Clausthal-Zellerfeld, Germany \\ ${ }^{4}$ Urweltmuseum GEOSKOP, Burg Lichtenberg (Pfalz), Thallichtenberg, Germany; j.fischer1@yahoo.de
}

The Elbe Valley in the surroundings of Dresden, Saxony (eastern Germany), in an area between Meißen and the Czech border, is dominated by Late Cretaceous sandstones, calcareous limestones, marls and marly limestones. These sediments were deposited during the late Cenomanian to late Turonian in a narrow sea strait connecting the Bohemian Cretaceous Basin in the southeast and the Boreal Sea in the northwest. These strata have yielded a rich fossil assemblage, including trace fossils, plants, marine invertebrates and aquatic vertebrates. Fishes are represented by rare coelacanth remains, diverse actinopterygian fossils, and abundant teeth, coprolites, and rare spine fragments attributable to 19 chondrichthyan taxa.

In two centuries of collecting, several dozen isolated calcareous neoselachian vertebral centra have been found, some of which were studied in detail and depicted in historical literature. No descriptions and systematic interpretations of this material, however, were published after 1900, while the knowledge on fossil shark vertebrae has immensely increased since the 1990s.

We restudied all available collection material, documenting metric and morphological features and reconstructing growth trajectories based on counts and measurements of the concentric growth increments. Three distinct morphotypes could be tentatively discerned and taxonomically interpreted. Size at birth, age and total length of the individuals have been estimated based on published equations.

Morphotype 1 comprises large centra with concentric growth marks and no prominent radial lamellae, a high diameter/length (d/l) ratio (3.4-3.6), and a birth mark diameter of 15-16.6 mm, pointing to a birth size of $87-97 \mathrm{~cm}$, and an adult size of 5 to $6 \mathrm{~m}$. Based on literature, we assign this morphotype to Cretoxyrhina, represented in Saxony by teeth of $C$. mantelli.

Morphotype 2 encompasses smaller vertebrae with a $\mathrm{d} / \mathrm{l}$ ratio of 2.3-2.8 and numerous radial lamellae perpendicular to the concentric growth rings. The birth size of the individuals is estimated to $23-44 \mathrm{~cm}$ and the adult length to $89-332 \mathrm{~cm}$. This morphotype is correlated with Cretodus, documented in Saxony by teeth of $C$. semiplicatus.

Morphotype 3 describes one centrum with a $\mathrm{d} / \mathrm{l}$ ratio of 3.3 , well-visible cartilage wedges, concentric and radial lamellae, and shorter radii of growth increments indicating slower growth compared to morphotypes 1 and 2 . The birth size is estimated to $95-98 \mathrm{~cm}$ and the adult length to 339-344 cm. It is tentatively interpreted as Ptychodus, known from Saxony by teeth of three different species.

Our study demontstrates that morphometric criteria are usable for taxonomic interpretation of isolated elasmobranch centra. Furthermore, it proves the possibility of a well-justified morphological differentiation within a fossil assemblage. 


\title{
Magnetic investigations of Lake Bannoe (South Urals) sediments
}

\author{
Dilyara M. Kuzina, Anastasia R. Yusupova, Kirill A. Voronov, Vadim V. Antonenko \\ Kazan Federal University, Kremlovskaya St.4/5, 420111 Kazan, Russia; di.kuzina@gmail.com
}

The work is devoted to the study of the magnetic parameters of the Bannoe Lake. The main aim of this investigation is to identify the presence of magnetic minerals and recognize their origin: cosmic, terrestrial (biogenic, volcanic etc.).

The object of research Lake Bannoe $\left(53^{\circ} 35^{\prime} 48.13^{\prime \prime} \mathrm{N} 58^{\circ} 37^{\prime} 47.28 " \mathrm{E}\right)$ is located in the Southern Urals. The altitude of the lake is $434 \mathrm{~m}$, the width is $\sim 1.9 \mathrm{~km}$, the length is $\sim 4.2 \mathrm{~km}$, and the basin area is $36.3 \mathrm{~km}^{2}$. The sediment section is represented by gray-blue clay with shell fragments, dark green to gray-green silts. According the radiocarbon dating the lake is $\sim 12.5$ thousand years of age.

The magnetic susceptibility (MS) was measured for all (254) samples of the core \#3 using MFK-1A (AGICO). The obtained values of the MS were normalized by weight. Coercive parameters of the core were obtained the $J$ meter coercive spectrometer. The magnetic hysteresis parameters reflect the size of magnetic particles, the composition of the magnetic grains, and the contribution of the para-, ferro-, and superparamagnetic components of the MS.

Measurements of magnetic susceptibility (MS), hysteresis parameters and thermomagnetic analysis were carried out to determine changes in magnetic mineralogy and sedimentation conditions. Thermomagnetic curves measured on Curie express balance, coercitive parameters on J-coercivity spectrometer and magnetic susceptibility on multi-function kappabridge MFK1-FA (AGICO). Thermomagnetic analysis is a major method for the diagnosis of ferromagnetic fraction composition in rocks. Differential thermomagnetic analysis (DTMA) of all (254) samples of core \#3 was carried out using a Curie express balance. Before measuring the dried sample was ground and weighed. Temperature dependences of induced magnetization up to $800^{\circ} \mathrm{C}$ at a heating rate of $100^{\circ} \mathrm{C}$ per minute in a constant magnetic field of $0.4 \mathrm{~T}$ were obtained. The curves of the first and second heating allow to evaluate possible mineralogical transformations in a sample.

The integrated analysis of magnetic parameters made it possible to divide studied core for several sections with different magnetic mineralogy and magnetic properties. Based on the data obtained, conclusions were drawn about the nature of magnetic particles in the sediment.

This study was funded by grant of the President of the Russian Federation for state support of young Russian scientists - candidates of sciences № MK-4100.2021.1.5. Part of the study was funded with the subsidy allocated to the KFU in context of state assignment \# 671-2020-0049. 


\title{
Traces of microbial activity in the sediments of near-bottom hydrothermal facies in pyrite deposits of the Urals
}

\author{
Lubov' V. Leonova1', Elena I. Soroka ${ }^{1}$, Natalia P. Safina², Akhmet A. Galeev ${ }^{3}$ \\ ${ }^{1}$ The Zavaritsky Institute of Geology and Geochemistry of the Ural Branch of RAS, Ekaterinburg, Russia; \\ Ivleonova@yandex.ru; elsoroka@yandex.ru \\ 2South Urals Federal Research Center of Mineralogy and Geoecology UB RAS, Institute of Mineralogy, \\ Miass, Russia;natali.safina2015@yandex.ru \\ 3Kazan Federal University, Kazan, Russia; akhmet.galeev@kpfu.ru
}

Currently, the leading role in the formation of pyrite deposits, both ancient and modern, is given to hydrothermal-sedimentary processes. It is suggested that the early accumulation of ore matter is associated with bottom hydrothermal facies. One of the signs of such conditions is the mineralized remains of macro- and microbiota. However, the subsequent influence of superimposed hydrothermal processes can lead to the erasure of the characteristic features of fossils, which makes it difficult to recognize them. At the same time, microfossils are able to persist longer than macro fauna remains. Therefore, their study is relevant.

At the pyrite deposits of Safyanovskoye and Yaman-Kasy (Ural), signs of the bottom accumulation of ore matter were found. The complex of mineralized remains of benthic macro fauna includes fossils of vestimentifer and polychaeta, bivalve mollusks, gastropods and brachiopods without locks. We have studied framboidal pyrite and well-preserved microconcretions, considered as a result of the vital activity of fossil microbial communities, including thionic bacteria. Morphological features are distinguished, such as concentric layering with a preserved fibrous (filamentous) structure inside the layers. The degree of preservation of these formations is not always the same. There are microconcretions with visible concentric layers, but without a distinct microstructure in the layers; with a layering noticeable in the marginal part of the microconcretion, or concretions modified to the so-called "shadow structures". Using the method of electron microscopy and energy-dispersion analysis, a number of variability of morphological features due to secondary processes is shown.

The analysis of the electron paramagnetic resonance spectra of carbon-siliceous near-ore rocks of the Safyanovskoye deposit showed the presence of two types of the $R_{\text {org }}$ carbon signal characteristic of plant (algae) and protein residues, and also that the organic matter was changed under heating conditions not higher than $300^{\circ} \mathrm{C}$. Overall results of research methods applied allow us to detect traces of the vital activity of microbial communities in the ore-bearing strata of deposits, and to more correctly interpret the genesis of primary deposits. 


\section{Permian ammonoids: results and prospects of Russian paleontologists's research}

Tatiana B. Leonova

Borissiak Paleontological Institute, Russian Academy of Sciences, Moscow, Russia; tleon@paleo.ru

Permian ammonoids are known at the different parts of the world. But studies of the Russian and Soviet paleontologists during almost two centuries have been essential for the development of Permian stratigraphy and evolutionary direction in paleontology of cephalopod.

Permian ammonoids played the leading role in the substantiation of all stages of the lower series of the Permian (Cisuralian). The Artinskian Stage was first established at the end of the $19^{\text {th }}$ century by A.P. Karpinsky, the Sakmarian Stage in 1938, and the Asselian Stage in 1954, both by V.E. Ruzhencev. The Carboniferous-Permian boundary was established and ratified based on changes in assemblages of conodonts, ammonoids, and fusulinids. Its stratotype (GSSP) was officially accepted in the Aidaralash Section (Kazakhstan), first proposed by V.E. Ruzhencev.

Permian ammonoids have been a subject of study since the recognition of the Permian system; the first described Artinskian taxon was Goniatites orbignyanus Verneuil, 1845.

From the mid-19 $19^{\text {th }}$ to the first decades of $20^{\text {th }}$ century was taking place the accumulation and generalization of data, including the first attempts to study phylogenesis. It is associated with such famous names as A.P. Karpinsky, P.I. Krotov, A.A. Chernov, T.M. Emelyantsev and others. The first collections of Permian ammonoids came mainly from the South Urals, later they were discovered in the Darvaz Range and in the Crimea.

In the middle of the $20^{\text {th }}$ century, starting in the 1930 s major progress was made, both in the study of taxonomic diversity and in the classification of the collected data, V.E. Ruzhencev made a huge contribution to the research of this group of fossils. At the same time, the foundations of ontophylogenetic studies of ammonoids were developed. The geography of the Permian ammonoid sites has expanded, as reflected in the publication of numerous regional works with monographic descriptions of the ammonoid faunas of the Northeast and Far East of Russia, as well as Central Asia and Transcaucasia. In the $21^{\text {th }}$ century Permian ammonoids were found in the Middle Permian (Kazanian) of the Volga-Ural region.

Currently, Permian ammonoid studies are very diverse, and along with the description of new taxa, reconstruction and analysis of the phylogenies and morphogenesis of taxa of family rank, include multidisciplinary ecosystem, morpho-functional and biogeographical research. Ammonoid biostratigraphy also remains in demand. 


\section{Terminal Carboniferous of the lower reaches of the Lena River (Northern Verkhoyanie, North-East of Russia): brachiopods and biostratigraphy}

Victor I. Makoshin, Ruslan V. Kutygin

Diamond and Precious Metal Geology Institute, Siberian Branch, Russian Academy of Sciences, Yakutsk, Russia; makoshin 89@mail.ru

The Kubalakh section is located on the right bank of the Lena River in its mouth part. It contains the stratotypes of most of the Upper Paleozoic formations of the Ust-Lena facies basin and has a long history of study. Almost all the Upper Paleozoic formations of the Ust-Lena basin are characterized by ammonoids, which make it possible to determine the geological age of the stratigraphic unit. An exception is the Kubalakh Formation, which is characterized mainly by brachiopods. Researchers presented contradictory data on the Kubalakh brachiopod assemblages, which belonged either to the Upper Carboniferous, or to the base of the Permian, or to the boundary Carboniferous-Permian interval. This was one of the reasons for the exclusion of the Kubalakh formation in 2002 from the Regional Stratigraphic Scheme of the Upper Paleozoic of the Northern Verkhoyansk. To resolve the issue of the validity and age of the Kubalakh Formation, in 2010 and 2019, we studied in detail the stratotype section of the formation located in the area of the Kubalakh Creek mouth. In the process of studying the stratotype, the lithological structure of the section was clarified and new paleontological material represented by brachiopods was collected.

The lower Kubalakh Subformation in the section is represented by monoclinal argillites, various-grained siltstones, and fine-grained sandstones. In the subformation, the species characterizing the Protoverkhoyanicus Zone have been identified: Jakutoproductus protoverkhoyanicus Kaschirzew, Verchojania abramovi Makoshin, Verchojania cf. monstrosus (Ganelin), Cancrinella? alazeica Zavodowsky, and Tornquistia kolymensis Afanasjeva. The Jakutoproductus protoverkhoyanicus Zone belongs to the upper part of the Kygyltasian Regional Stage (Gzhelian) of Verkhoyanie and earlier it was identified by us in the boundary CarboniferousPermian sections of the Kuranakh and Barajy facies basins. The Upper Kubalakh Subformation is assigned to the Permian system (Asselian) by the presence of the Khorokytian taxa of Verkhoyanie (Jakutoproductus verkhoyanicus Zone).

The Kubalakh Formation has peculiar lithological characteristic and paleontological associations, different from the underlying and overlying sediments. This indicates the undoubted validity of the Kubalakh Formation, which is of the Gzhelian-Asselian age (Protoverkhoyanicus Zone and lower part of Verkhoyanicus Zone). 


\section{Mineral composition of the Saki mud}

Gleb S. Maksimov, Igor A. Nauhatsky

Physical and technical Institute, V.I. Vernadsky Crimean Federal University, Simferopol, Russia; neondreamer00@gmail.com

The history of Crimean resorts began with the Saki Lake's therapeutic mud. In the first half of the 19th century, a mud resort was opened in Saki (Saki is a small town in the west part of Crimea) for the first time in the world. The famous doctor Pirogov during the Russian-Turkish war recommended procedures using mud to accelerate wound healing.

Practical therapeutic properties of Saki mud are determined by the content of biological active components and unique chemical composition. According to X-ray phase analysis, the composition of Lake Saki mud includes gypsum, halite, calcite, aragonite and bassanite. The predominance of the sulfate-carbonate type of Saki mud with a high content of carbonates is noted.

The mineral composition of the sample of Saki mud studied by X-ray diffractometry and spectroscopy. Structural studies were performed on a Bruker D8 Advance X-ray diffractometere. The elemental composition was determined using a Supermini 200 fluorescent wave dispersive spectrometer (Rigaku).

The mineral composition of the Saki mud contains: $30.2 \%$ nontronite ( $\mathrm{Na}$, $\mathrm{Ca})_{0.3} \mathrm{Fe}_{2}(\mathrm{Si}, \mathrm{Al})_{4} \mathrm{O}_{10}(\mathrm{OH})_{2} \cdot \mathrm{H}_{2} \mathrm{O}, 26.9 \%$ gypsum $\mathrm{CaSO}_{4} \cdot 2 \mathrm{H}_{2} \mathrm{O}, 15.4 \%$ calcite $\mathrm{CaCO}_{3}, 12 \%$ calcium sulfate hydrate $\mathrm{Ca}\left(\mathrm{SO}_{4}\right) \cdot(\mathrm{H} 2 \mathrm{O}), 10.1 \%$ halite $\mathrm{NaCl}$ and $5.3 \%$ low-symmetric quartz $\mathrm{SiO}_{2}$. 


\section{The Permian-Triassic boundary in the Barents Sea}

Elena Malysheva ${ }^{1}$, Maria Doronina ${ }^{2}$, Ludmila Kleschina ${ }^{1}$, Vera Nikitina ${ }^{1}$, Andrey Popov ${ }^{1,2}$, Natalya Vasilyeva ${ }^{2}$

${ }^{1}$ RN-Shelf-Arctic LLC, Moscow, Russia; namalysh@mail.ru,

${ }^{2}$ RN-Exploration LLC, Moscow, Russia; BC "Atlantic", Moscow, Russia

The Permian-Triassic (P-T) transition is regarded to be the most dramatic episode in Phanerozoic history. It is marked by greatest global mass extinction, tectonic and volcanic activities in many areas around the world. In some areas with non-marine deposition it corresponds to obvious stratigraphic unconformity marked by abrupt lithology and facies change and confirmed biostratigraphically. In other areas P-T boundary is gradual, confined to marine relatively deepwater environments. However, there are areas such as Eastern European platform where it remains uncertain and controversial because of lack of biostratigraphic data. The Barents Sea always attracted much interest of researchers because of it's location between such areas.

Current study focused on correlation and characterization of P-T transition was carried out within the projects of RN-Shelf-Arctic LLC and RN-Exploration LLC and based on regional and composite seismic lines, local 3D and well data in nearshore zones, provided by Russian and Norwegian companies. Combination of regional projects from Russian and Norvegian sectors, unique data base and application of sequence stratigraphy technics provided new approach to the correlation and interpretation of P-T boundary across Barens Sea and adjacent areas.

Seismic crossections from Pechora sea to Norwegian shelf reveal several types of P-T transition. Very distinct sequence boundary (SB) marked by toplap and obvious erosional truncation of the layers confined to P-T boundary is identified in southern part of the Barents Sea (Pechora Sea). Basing on biostratigraphic data in wells it corresponds to the boundary between Kazanian-Tatarian and Induan stages and very often is characterized by abrupt change in petrographic and facies composition. It is regarded as «eastern» erosional type of P-T transition. $3 \mathrm{D}$ seismics in the coastal zone reveals excellent view of alluvial valley at the base of Triassic.

Central the Barents Sea represents «central overcompensated» relatively conformable transition with additional Lower Triassic interval. It displays thick chaotic section of mass transport deposits (?), accumulated from significantly eroded shelf and corresponds to the time of this erosion between the Permian and the Triassic. Only above this chaotic interval downlapping clinoforms both from the East and the West appear.

Westward in the direction of Norwegian sector of the Barents Sea the "transition" zone is represented by condensed section, corresponds to relatively deep water paleoenvironments and could be regarded as «western condensed» type of P-T transition. Well data in Norwegian sector provide information about Kazanian-Tatarian to Induan age and outer to inner shelf marine facies in transition section.

It should be mentioned that Triassic section especially in the central part of the sea is strongly disturbed by igneous sills. 


\section{The Permian-Triassic trace fossils of the Southern Verkhoyansk Region (Tiryakh-Kobyume Section, Sakha-Yakutia)}

Dinara N. Miftakhutdinova, Ruslan V. Kutygin

Kazan Federal University, Kazan, Russia; dinyamift@gmail.ru

Diamond and Precious Metal Geology Institute, Siberian Branch, Russian Academy of Sciences, Yakutsk, Russia

This contribution presents the first detailed evidence for Permian and Early Triassic ichnofossils of the Southern Verkhoyanye region. The aim of the work is to discuss the possibility of using ichnofossils for reconstruction of terrigenous sedimentation environments at high latitudes, including those related to the events of the End-Permian Mass Extinction.

The results are based on ichnofacial and ichnotextural analyses of about 600 samples collected in 2019 from the Tiryakh-Kobyuma section.

We found that Permian and Triassic deposits of the studied section contain numerous ichnofossils attributed to 11 ichnogenera. Four ichnoassemblages have been identified, which are referred to two ichnofacies - Zoophycos and Skolithos.

The Zoophycos ichnofacies includes two ichnoassemblages: Helmintopsis-PhycosiphonZoophycos and the depleted Helmintopsis-Phycosiphon assemblage. This ichnofacies is confined to well-sorted substrates formed in calm, relatively deep-water shelf environments, below storm wave base, with reduced oxygen content.

The Skolithos ichnofacies includes two ichnoassemblages: Arenicolites-Skolithos and Diplocraterion-Arenicolites, and is characteristic of coastal environments with active hydrodynamics and large influx of clastic and organic material.

The ichnofacies alternate across the section, reflecting sedimentological changes during accumulation.

The sediments of the lower part of the Nekuchan Formation, corresponding to the EndPermian Mass Extinction event, accumulated under calm conditions of a relatively deep shelf. This interval is characterized by the Zoophycos ichnofacies with a depleted Helmintopsis-Phycosiphon ichnoassemblage. The depletion of the ichnoassemblage and the absence of benthic fossils in this part of the section may be caused by anoxic conditions at the basin bottom.

The obtained reconstruction of the Permian and Early Triassic environments is in good agreement with the results of previous studies based on sedimentological and biofacial data. 


\section{Ichnofacial analysis of the Pashyian and Timanian Regional Stages (Devonian) of the Southern Tatarian Dome (East European Platfotm)}

Dinara N. Miftakhutdinova1, Vladimir V. Silantiev, Nuriia G. Nurgalieva, Ilja Kogan², Rishat M. Habipov ${ }^{3}$, Kirill D. Shumatbaev ${ }^{3}$, Vladislav A. Sudakov ${ }^{1}$, Marat F. Validov ${ }^{1}$

${ }^{1}$ Kazan Federal University, Kazan, Russia; dinyamift@gmail.ru

${ }^{2}$ TU Bergakademie Freiberg, Freiberg, Germany

${ }^{3}$ PJSC TATNEFT, Almetevsk, Russia

This contribution investigates the depositionary condition of Devonian sediments within the Southern Tatarian Dome of the Volga-Ural oil and gas province. The study is based on the ichnofacial and ichnotextural analysis of samples selected from 12 Pashiyan and Timanian drill cores and documented lithologically, palaeontologically and palinologically.

The Southern Tatarian Dome (STD) is a first-order tectonic positive structure within the Volga-Ural province. It involves sedimentary successions of the Upper Palaeozoic and controls the unique Romashkino oil field as well as a number of further significant oil fields.

According to palaeogeographic reconstructions (Golonka, 2002, 2020; Torsvik and Cocks, 2017), the present-day Volga-Ural province was located in the equatorial part of the northeasternmost Laurasia during the Devonian (Fig.1). The passive continent margin, facing the Ural Ocean, was aligned along the equator. This position led to the development of sublatitudinal facies belts (including reef belts, extending for up to 2500 km) (Antoshkina, Königshof 2008).

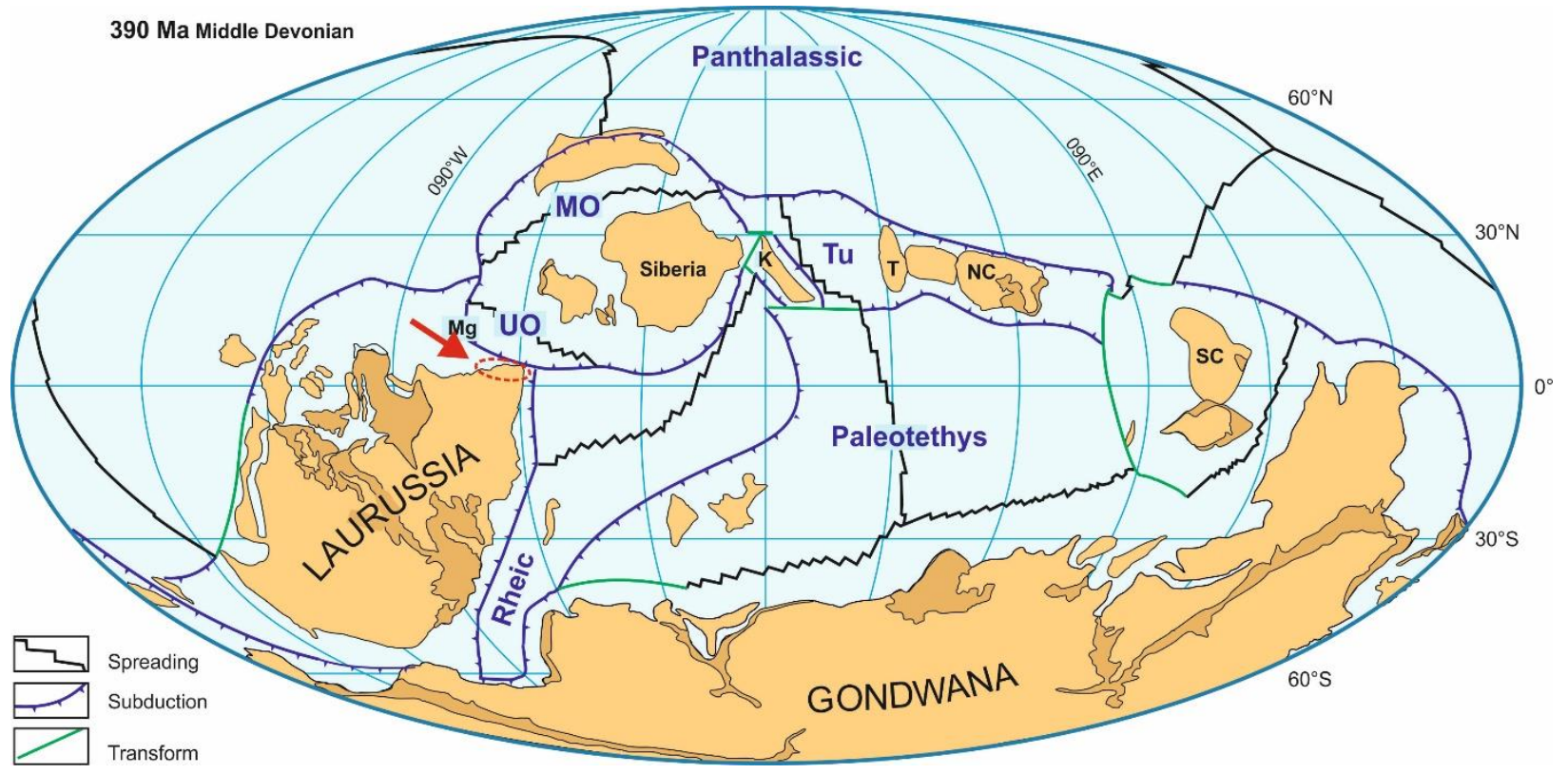

Fig. 1. Palaeogeography of the Middle Devonian (390 Ma) and location (red arrow and red dotted oval) of Volga-Ural area. Terranes and continents: NC, North China; SC, South China; T, Tarim. Oceans and Island Arcs: Mg, Magnitigorsk Arc; Mo, Mongol- Okhotsk Ocean; Tu, Turkestan Ocean; UO, Ural Ocean. Maps based on Golonka (2002, 2020), Torsvik and Cocks (2017), Scotese (http://www.scotese.com/earth.htm) and Blakey (https://deeptimemaps.com)

The stratigraphic interval of the Pashyian and Timanian Regional Stages comprises the Middle/Upper Devonian boundary and encompasses deposits whose formation correlates with two global transgressions. 
Deposition of the Pashyian horizon can be related to the Taghanic onlap in the second half of the Givetian (Johnson, 1970). Accumulation of the Timanian horizon sediments can be related to the Early Frasnian transgression.

Palaeotemperature calculations based on conodont phosphate (Joachimsky et al., 2009) indicate high (up to $30^{\circ} \mathrm{C}$ ) tropical ocean water temperatures at the beginning of Early Devonian (Lochkovian) and in the second half of the Frasnian and Famennian.

The second half of the Early Devonian and the Middle Devonian (405-385 Myr), in contrast, were characterized by cool climatic conditions (Joachimsky et al., 2009).

Within the Southern Tatarian Dome, the Pashyian and Timanian Regional Stages complete the succession of the so-called Devonian siliciclastic complex. This complex is characterized by a distinct rhythmicity caused by the Givetian-Frasnian marine transgression (Danilova, 2008; Fortunatova et al., 2013). According to the Russian Interdepartmental Stratigraphic Committee's scheme (Postanovleniya..., 2008), the base of the Frasnian probably coincides with the base of the Upper Timanian Regional Stage. The authors, following Fortunatova et al. (2013) accept the Givetian/Frasnian boundary as the base of the Timanian Regional Stage, which is approximately comparable with the beginning of the marine transgressive cycle.

The Timanian Regional Stage is represented within the STD by a succession of carbonates and terrigenous rocks. Conventionally, the Timanian deposits begin with the Upper Limestone marker bed, concordantly overlying the Pashyian sediments; this is overlain by units of claystones with siltstone and sandstone interbeds.

Only clastic sediments - sandstones, siltstones and mudstones - form the succession of the Pashyian Regional Stage within the STD.

Deposits of the Timanian Regional Stage are characterized by a variety of ichnofossils and a high bioturbation index. Bioturbation destructs the original sediment stratification and primary structures. The degree of bioturbation of the Timanian rocks varies from 60 to $100 \%$.

The highest diversity of trace fossils occurs in the thinly interbedded mudstones and sandstones. Here they are represented by the Skolithos ichnofacies. Vertical spiral Spirophyton burrows (element of Zoophycos ichnofacies) are found in marine sandstones.

Skolithos ichnofacies is confined to coastal-marine settings, foreshore to upper and middle shoreface environments of wave-dominated shorelines (Buatois, Mangano, 2011).

Zoophycos ichnofacies is indicative of offshore, relatively deep-water conditions far from the shoreline below storm wave base.

Pashyian sediments vary in their development among drill cores between shallow-water and deep-water facies. In shallow-water sediments, bioturbation is rarely observed, mainly in intervals of interbedding sandy and clayey rocks. Deep-water sediments are often heavily bioturbated. Increased reservoir properties are typical for sediments of the shallow-water facies.

\section{REFERENCES}

Antoshkina A. Lower Devonian reef structures in Russia - an example from the Urals / A. Antoshkina, P. Königshof // Facies. - 2008. - V. 54. - P. 233-251.

Lakey $R$. DeepTimeMaps ${ }^{\mathrm{TM}}$, https://deeptimemaps.com [accessed 21 August, 2021].

Buatois L. Ichnology. Organism-Substrate Interaction in Space and Time / L. Buatois, M.G. Mangano. Cambridge: Cambridge University Press - 2011. - V. 358. - P. 197-216. doi:10.1017/CBO9780511975622

Danilova T.E. Terrigennye porody devona b nyzhnego karbona. Ministerstvo ekologii i prirodnykh resursov RT, Akademiya nauk RT, Kazan: Pluton, 2008. - 18 p. (in Russian).

Fortunatova N.K. Stroenie devonskogo terrigennogo kompleksa i polozhenie granitzy srednego I verchnego devona na zapade Tatarstana / N.K. Fortunatova, E.L. Zaycheva, O.A. // Bulleten` 
MOIP Otd. geol. - 2013. - V. 88, iss. 2. - P. $22-49$ (in Russian).

Golonka J. Plate-tectonic maps of the Phanerozoic / J. Golonka // Society for Sedimentary Geology Special Publications. - 2002. - V. 72. - P. 21-75.

Golonka J. Late Devonian paleogeography in the framework of global plate tectonics / J. Golonka // Global and Planetary Change. - 2020 - V. 186. - No 103129. https://doi.org/10.1016/j.gloplacha.2020.103129

Joachimski M. Devonian climate and reef evolution: Insights from oxygen isotopes in apatite / M. Joachimski, S. Breisig, W. Buggisch, J. Talent, R. Mawson, M. Gereke, J. Morrow, J. Day, K. Weddige // Earth and Planetary Science Letters. - 2009. - V. 284, iss. 3-4. - P. 599-609.

Johnson J.G. Taghanic onlap and the end of North American Devonian provinciality / J.G. Johnson // Geological Society of America Bulletin. - 1970. - V. 81. - P. 2077-2105.

Postanovleniya Mezhvedomstvennogo stratigraficheskogo komiteta i ego postoyannykh komissii'. Vypusk 38. Sostoyanie izuchennosty stratigrafii dokembriya i fanerozoya Rossii. Zadachi dal'neyshikh issledovanii. - St. Petersburg.: Izdatel 'tsvo VSEGEI, 2008. - 58 p. (in Russian) Torsvik T.H. Devonian. Earth History and Palaeogeography / T.H. Torsvik, L.R.M. Cocks. Cambridge: Cambridge University, 2017 .- P. 138-158. 


\title{
Lithofacies and sequence stratigraphy interpretation of the Pokurskaya Formation in the Cenomanian Succession, north of the West Siberian Basin
}

\author{
Nosheen Mohammad, Nuriia G. Nourgalieva \\ Kazan Federal University, Kazan, Russia; nosheen.g.mohammad@gmail.com
}

The Cretaceous oil- and gas-prone terrigenous successions of West Siberian Basin are characterized by a complex lithofacies composition, the recognition of which affects the success of prospecting and exploration and exploitation works.

The purpose of this study was the lithofacies reconstruction of terrigenous rocks of the Pokurskaya Formation of the Cenomanian age at one of the gas condensate fields in the north of West Siberia. The main tasks included analyzing the electrical logs of six wells along the sublatitudinal profile of the field and modeling the profile in terms of signatures of electrometric facies and sequences.

The investigated section is represented by a complex alternation of shallow-sea sandstones, siltstones and mudstones with a total thickness of $\sim 200 \mathrm{~m}$, clearly distinguished on electric log curves.

The methodological basis for recognizing facies was the nature of the spontaneous potential in terrigenous sediments and the Muromtsev's modernized classification of electrometric facies by aSP changes.

As a result, the lithostratigraphy heterogeneity of the section was estimated by using the coefficients of the relative number and the thickness of layers with the size of clastic grains corresponding to low and medium-high paleohydrodynamic levels. The obtained estimate corresponds to the regional trend in the evolution of sedimentation.

Four major types of electrometric lithofacies (Foreshore, Regressive Shoreface, Transgressive Shoreface, and Discontinuous Currents) were recognized by examining the log curves. They form parasequences that compose four sequences of $0.3-0.5 \mathrm{Ma}$ (4rd order) with different number of surfaces and stacking elements. The studied logged section demonstrated the stacking of parasequences as result in 3rd order progradation with a significant component of aggradation in accordance with stratigraphic trend in the Cenomanian, where the normal regressive shoreline trajectory of successive parasequences is predictable.

The results contribute to development of ideas on terrigenous reservoir patterns and facies modeling in petroleum basins. 


\title{
New localities of the Early Triassic terrestrial vertebrates of the upper part of Luza River (Komi Republic, Russia)
}

\author{
Boris I. Morkovin ${ }^{1}$, Justyna Slowiak², Andrey V. Podlesnov ${ }^{1}$, Igor V. Morkovin ${ }^{3}$ \\ ${ }^{1}$ Borissiak Paleontological Institute, Russian Academy of Sciences, Moscow, Russia; prodeo27@yandex.ru \\ ${ }^{2}$ Department of Evolutionary Paleobiology, Institute of Paleobiology, Polish Academy of Sciences, \\ Warsaw, Poland \\ ${ }^{3}$ Independent researcher, Moscow, Russia
}

The studied area is placed to the East of the Moscow syneclise, the largest negative platform structure of the East European Platform.

Mainly continental deposits were accumulated here during the Early Triassic.

The sequence of the Lower Triassic deposits is visible in numerous outcrops located along the right riverside of the Luza river from the district center of Obyachevo to the Onmes village. Currently, the Lower Triassic Formations known from the studied place are subdivided into the Sludkian, Ust-Mylian, Fedorovskian and Gamskian Formations (Lozovskiy et al. 2011).

First informations about the findings of terrestrial vertebrates in the mottled sediments of the Luza river basin were reported by geologists L.I. Lutugin and V.G. Khimenkov. The presented paleontological materials allowed N.N. Yakovlev to establish the Triassic age of the enclosing rocks for the first time.

Between 1930 and 1960, the stratigraphy of the localities with terrestrial vertebrate fossils were studied by I.A. Efremov, M.F. Kuzmin, O. A. Solntsev, and others. Up to the 60's, the geological work was not performed in the studied area. More detailed description of the Lower Triassic stratigraphy with description of the new paleontological findings was reported in the later 60 's. In this regard, K.K. Vollosovich, A.N. Nochkin, as well as the authors of thematic works (G.I. Blom, V.R. Lozovsky, M.A. Shishkin, V.G. Ochev and V.I. Rozanov, M.G. Minikh, A.V. Minikh and others) that became the basis for the stratigraphic interpretations of the Lower Triassic Formations.

Later, the study of the Lower Triassic deposits in the Luza riverside was provided by I.V. Morkovin (1999) in several new localities classified to the Vetlugian and Yarenskian parts of the record. The Skoba (Mikush) locality is unique among similar in age Formations of the Lower Triassic sediments of the East European Platform (Morkovin and Novikov 2000).

A significant impact had the publication of S.N. Mityakov et al. (2013) of the geological map of the Russian Federation in scale 1: 200,000, Mezenskaya series, sheet R-39-XXXII (Obyachevo).

In the period from 2016 to 2021 the field studies of the Lower Triassic deposits in the Southwestern part of the Komi Republic, Luza's river head and its tributaries were continued under the leadership of B.I. Morkovin (Paleontological Institute of the Russian Academy of Sciences). During the field work, supported by the RFBR project (No. 20-05-0009), new data about the biostratigraphy and taphonomy of the Lower Triassic deposites were obtained in previously known localities and three new localities with terrestrial vertebrate fossils were discovered.

All the new localities reported show the same structure and are limited to mainly of sandy lenses in variegated clays. Despite the general similarity, the localities occupy different stratigraphic position and contain various faunal assemblages that can be distinguished to three stratigraphic horizons: the Sludkian, the Ust-Mylian of the Vetlugian Superhorizon, and the Fedorovskian horizon of the Yarenskian Superhorizon.

Each of the new localities, although the general similarities of the structure, shows distinctive specificity, due to the facies differences. So, e.g., the Piclachol area (PIN col. 5833), 
located $5 \mathrm{~km}$ from the Veldoria village, has one bone-bed level, probably associated with the basin facies of the Fedorovskian horizon. It is evidenced by the abundance of fish remains, i.e., subtle features of the structure on the fragmentary skulls. The Yuzpoziu locality (PIN col. 5835), placed 7 $\mathrm{km}$ from the Onmes village, is characterized by the presence of two bone-bed levels. The lower level is characterized by clay facies indicating low-energy environment, with bone-bed sandy nodules characterizing the Upper Vetlugian Superhorizon. The upper level is characterized by sandy lens among the alluvial facies of the Fedorovskian horizon. A similar two-level structure is present in the Oshkayol area (PIN col. 5834), located $11 \mathrm{~km}$ from the Onmes village. The main difference in the latter is the abundance of reptile fauna in the alluvial facies, both at the lower Upper Vetlugian and Upper Yarenskian horizon.

Thanks to a lot of filed work, numerous specimens of fossil terrestrial vertebrates and fish remains were obtained. Most of the findings are identified as belonging to temnospondyls labyrinthodonts (Vladlenosaurus alexeyevi, Wetlugasaurus sp., Parotosuchus sp.). The remains of reptiles (Microcnemus sp., Tichvinskia sp.), Bystrowianids reptiliomorphs (Vyushkoviana sp.) and fishes (Gnathoriza lozovskii, Gnathoriza sp., Ceratodus sp.) were also identified.

A particular attention is required to the discovery of complete skulls of procolophonids in articulation with the lower jaws. They are initially identified as Tichvinskia sp. The well-preserved skulls are relatively large in size, up to $4.5 \mathrm{~cm}$. For the first time fulll skulls of procolophonids in the studied area are reported, previously only their fragmentary remains were known from there.

The new localities are also interesting due to the stratigraphic distribution of the Lower Triassic deposits of the Luza's river head. Earlier, the researchers (Mityakov S.N. et al. 2013) reported more ancient deposits close to the Onmes village of the Rybinskian horizon of the Shilikhian Formation. The presence of such deposites is not confirmed by our new studies, which indicate a wider distribution of the deposits of the Upper Vetlugian and Yarenskian Superhorizons in this area. 


\title{
Paleosols from the Upper Kazanian red beds of Sentyak section: preliminary results
}

\author{
Fedor A. Mouraviev, Vladimir V. Silantiev, Tatiana V. Kropotova \\ Kazan Federal University, Kazan, Russia; fedor.mouraviev@yandex.ru
}

The section of the Kazanian near the village of Sentyak is the reference section for the Lower Kama region. The Upper Kazanian in this area is composed entirely of red-bed rocks containing non-marine fossils. This work presents the first results of the study of Upper Kazanian paleosols of this section. The study methods included field description, analysis of carbonate content of soils, optical microscopy, scanning electron microscopy (SEM) and X-ray diffraction.

The paleosols in this section are mainly confined to the middle part of Upper Kazanian within the 40-m interval. The host rocks are siltstones, clayey siltstones, and silty sandstones; often paleosols are overlain by thick-bedded lacustrine-palustrine limestones with ostracod fauna and root imprints. Prevailing soil orders in the section are (calcic) Protosols and calcic Argillisols, the thickness of soil profiles does not exceed $1.2 \mathrm{~m}$. The topsoil (A horizon) of soil profiles is commonly eroded; the stage of development of paleosols is weak to moderate, the most developed paleosols include $\mathrm{Bk}$ and $\mathrm{Bw}(\mathrm{Bt})$ horizons.

The main pedofeatures of paleosols under study are drab-yellow root traces, angular blocky peds with illuvial clay cutans on their surfaces and carbonate nodules up to $2-3 \mathrm{~cm}$ in size. Redoximorphic features are poorly expressed and are represented by a yellowish mottles on a reddish-brown soil background. The carbonate content of paleosols ranges from 8 to $30 \%$, on average $15-17 \%$. The mineralogy of siliciclastics is represented by quartz, siliceous rocks, and, to a lesser degree, feldspars and mica, the clay fraction is represented by chlorite, muscovite, smectite and kaolinite. The pedogenic nodules consist of calcimicrite, with typical alpha-fabric micromorphology. SEM studies revealed the frequent presence of microbial films and fungal mycelium both in the silty-clayey mass and in the carbonate nodules of paleosols.

In general, compared with the previously studied Urzhumian paleosols of the reference sections of Kazan Volga region, the Upper Kazan paleosols of the Sentyak section are less mature and more automorphic, there are no stacked paleosols and calcretes. The presence of kaolinite in the clay fraction of paleosols may indicate a more humid climate during Kazanian. 


\title{
A fertile branch of Lepidodendron obovatum Sternberg from the Lower Carboniferous (Visean) deposits of the Kaluga region, Russia
}

\author{
Serge V. Naugolnykh¹, Olga A. Kokina \\ ${ }^{1}$ Geological Institute of Russian Academy of Sciences, Moscow, Russia; naugolnykh@list.ru
}

The fertile specimen of a lepidodendrid branch was found in the shallow-water marine deposits outcropped in the famous Ferzikovo section, Kaluga region. This uncommon find adds new details on possible organization of fertile shoots/branches of early Carboniferous lepidodendrids of Russia. A single although well-preserved specimen, which is a subject of the present report, represents a considerable part of the lepidodendrid branch with a cone preserved near the branch presumably in the natural connection/attachment to this branch. The mode of preservation is an imprint with a small amount of coalified plant tissues, which are not good enough for maceration.

The plant fossil, which is in the scope of the present study, is a representative fragment of long branch/stem of typical lepidodendrid morphology. The length of the branch fragment is $18 \mathrm{~cm}$, the width is $2 \mathrm{~cm}$. Although the branch was somewhat diagenetically deformed (compressed and flatten), we can suppose that the original shape of the branch was more or less subcylindrical.

The branch surface is covered by distinct leaf cushions of rhombic shape. Average size of the leaf cushions is $5 \mathrm{~mm}$ long and $4.5 \mathrm{~mm}$ wide, so the shape of the leaf cushion is more or less isometric or short-prolonged. The most well-preserved leaf cushions demonstrate medial prolonged rib ("keel") and a leaf scar disposed just above this rib or keel. Morphology of the leaf cushions is very similar to morphology of the wide-spread lepidodendrid species Lepidodendron obovatum Sternberg. Some of the leaf cushions, which are observed in lateral areas of the branch, show distinct acute apical appendages, which can be interpreted as partly preserved leaves (phylloids). The phylloids are relatively short, of subtriangular shape, scale-like.

A stalked well-visible cone-like structure is preserved just near the branch. Overall gross morphology of the cone-like structure left no doubts that it is a lepidodendrid cone (strobilus). The place of possible attachment of the cone stalk to the branch initially was covered by sediment (Fig. 1, A), but after careful preparation it was discovered that the stalk was attached directly to the branch. Moreover, careful study of the branch surface allowed to find two more scars of lateral attachment of some appendages, most probably, also cones of the same type.

The cone is of subcylindrical shape, although diagenetically flatten, with more or less obtuse stalked base and acute apex. The length of the cone is $70 \mathrm{~mm}$, the maximal width is 17 $\mathrm{mm}$. The maximal width of the cone is disposed near the cone basis in the lower one/third part of the cone. The cone consists of the numerous long and narrow sporophylls with needle-like apical segment. An average length of the apical segment is about $20 \mathrm{~mm}$, the maximal width of the apical segment varies from 1.5 to $2 \mathrm{~mm}$. Some of the sporangia are visible in axial area of the cone. The sporangia are of ovoid to round shape, about $2 \mathrm{~mm}$ in diameter. No spores were found inside the sporangia. Thus, each sporophyll consists of fertile proximal part with adaxially disposed sporangium, and distal sterile segment with the basis of $1.5 \mathrm{~mm}$ wide and acute apex. Sprophylls form unclear parastichi on the cone axis. The cone stalk is $11 \mathrm{~mm}$ long and $2 \mathrm{~mm}$ wide, arc-like curved. 

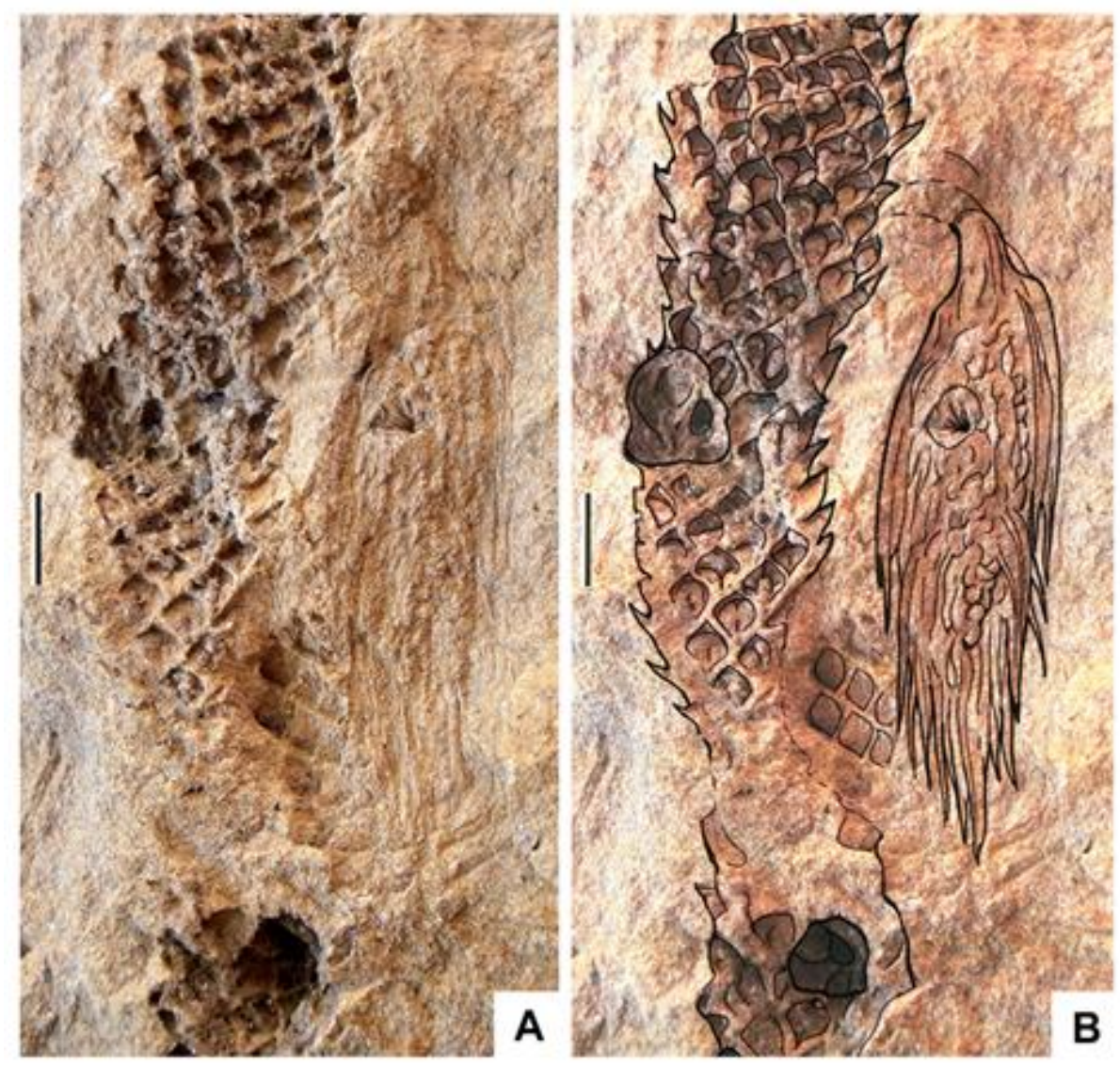

Fig. 1. Fertile branch of Lepidodendron obovatum Sternberg, the fossil (A) and interpretative linetracing (B). The Ferzikovo section, Kaluga region; Lower Carboniferous, Visean. Scale bar is $1 \mathrm{~cm}$.

General shape of the cone altogether with the position of the one beat the fertile branch point to the possible pendant pattern of the cone attachment when the parent plant was alive. 


\title{
Evidence of sexual dimorphism in smooth Permian ostracods
}

\author{
Maria A. Naumcheva \\ Borissiak Paleontological Institute of Russian Academic of Science, Moscow, Russia; paleomasha@mail.ru
}

The Staroe Slukino section (Vladimir region, Upper Permian) contains a lot of remains of freshwater ostracods. The most diverse community is in the bed 11, outcrop 1533. We found there a very variety association of subtriangle shells which was identified as species Suchonella clivosa Mishina, 1980. However, the big variety of the shells forces us to make sure that all of them could be belong to the same species. In this research, we aimed to understand the structure of the association (is it homogeneous or not) and to clear the reasons for such variance.

We choose 97 specimens with the best preservation and took photos of them from the left side by the Scanning Electron Microscope (TESCAN VEGA-II XMU). We evaluated shape changes using the Morphomatica software. This program superimposes digitized outlines of shells (tpsDig program was used for the shell digitizing) and calculates the area of non-coincident parts. As a result, we have a matrix of similarity of the shell shapes. In addition, we measured each specimen by the method of right triangles (Naumcheva, 2019) to identify the morphological traits which distinguish the specimens.

Cluster analysis (k-means) of the matrix showed that the association contains two clusters. The shells from the cluster 1 (C1) in comparison with those from the cluster 2 (C2) have the bigger height, the anterodorsal arc is steeper, the posterodorsal arc is lower, the posteroventral arc is more convex, the anterior point of maximum curvature is lower, and the ventral concavity is longer and deeper.

The clusters have morphological differences, but these are not so significant to separate the specimens into two different species. We believe the clusters show interspecies variability. The clusters are not connected with the size of the shells. Therefore, we can exclude an ontogenetic explanation. All specimens occur from one bed and one sample, so we suppose that the entire association existed in a similar environmental condition. Based on that assumption, we exclude ecological variability as an explanation. Most likely, the clusters reflect sex dimorphism. We believe that the C1 shells could belong to females and C2 shells - to males. Genus Suchonella is a part of the suborder Darwinulocopina. The females of recent representatives of the suborder have a brooding chamber in the posterior part of the carapace. Therefore, females' shells are higher and wider than males' ones.

Sex dimorphism of nonmarine Permian ostracods was noted before, but it was never approved on statistical data. Such an approach to the investigation of smooth Permian ostracods could show how common this type of variability is, make the definitions more reliable and reduce the number of synonyms. 


\title{
Paleovegetation reconstruction for the central part of Yamal Peninsula based on the pollen analysis from the Lake Neyto-Malto sediments
}

\author{
Gulnara R. Nigamatzyanova ${ }^{1}$, Niyaz M. Nigmatullin ${ }^{1}$, Irina V. Fedorova ${ }^{2}$, Larisa A. Frolova ${ }^{1}$ \\ ${ }^{1}$ Kazan Federal University, Kazan, Russia; GuRNigamatzyanova@kpfu.ru \\ ${ }^{2}$ Saint-Petersburg state university, Saint-Petersburg, Russia
}

The bottom sediments of Arctic lakes, which are sensitive indicators of global ecological and climatic changes, represent a kind of paleoclimatic and paleogeochemical archives. Pollen and spores are among the biological paleoindicators of ecological conditions. Pollen analysis gives an idea about vegetation dynamics, climate history and sediment stratigraphy. Palynological analysis, which previously has not been carried out on the Neytinskie lakes in the central part of Yamal, will provide more complete information on changes in vegetation and ecological conditions of the past. The object of research - the Lake Neyto-Malto. The maximum depth of the lake reaches $21 \mathrm{~m}$, the average depth is $3 \mathrm{~m}$, and the area is $220 \mathrm{~km}^{2}$. A column of sediments $16 \mathrm{~cm}$ long $\left(70^{\circ} 12^{\prime} 125\right.$ "N, $70^{\circ} 22^{\prime} 592 "$ E) has been collected in July 2020. Spore-pollen analysis demonstrated a low concentration of pollen grains and spores in the sediments and a high percentage of redeposited pollen. Pollen records revealed the development of tundra communities around the lake, represented by dwarf shrubs (Betula sect. Nana, Alnobetula, Salix sp. and Ericaceae), moss (Sphagnum spp.) with the participation of sedges (Cyperaceae) and forbs (Artemisia sp., Amaranthaceae, Poaceae, etc.). The lower part of the column formed during cold and humid periods. A decrease of the total concentration of pollen, as well as the change in the dominants of conifers in the sediments, indicate colder environmental conditions during the laying of the upper part of the core. In general, during the formation of bottom sediments of Lake Neyto-Malto the climate can be characterized as severe. The palynological analysis was supported by grant from Russian Scientific Foundation (No 20-17-00135). The statistical analysis has been conducted at the expense of funds of the subsidy allocated to Kazan Federal University for the state assignment \#671-2020-0049 in the sphere of scientific activities and by the Kazan Federal University Strategic Academic Leadership Program. 


\section{Subrecent spore-pollen spectra from Lake Onego (the European part of Russia)}

Gulnara R. Nigamatzyanova1, Vera D. Strakhovenko², Larisa A. Frolova ${ }^{1}$

${ }^{1}$ Kazan Federal University, Kazan, Russia; GuRNigamatzyanova@kpfu.ru

2VS Sobolev Institute of Geology and Mineralogy of the Siberian Branch of the Russian Academy of Sciences, Novosibirsk, Russia

Subrecent spore-pollen spectra reflect the composition of modern plant communities and they are the basis for interpretation of palynological data in paleoecological and paleoclimatic reconstructions. In addition, the palynological study of lake bottom sediments, which record and store an information about changes of climate, landscapes and ecological conditions of the past, makes it possible to reconstruct the development course of water bodies and their ecosystems. The purpose of current study is to determine the composition and distribution characteristics of spore-pollen spectra in the dispersed (in sedimentation traps) and concentrated form (in bottom sediments) of the sedimentary matter of Lake Onego based on the research results of 2019. For the palynological analysis of the pollen deposited in Lake Onego, we collected 23 samples of surficial bottom sediments from different parts of the lake water area (the upper 10-cm layer of sediment) and 4 samples of suspension from sedimentation traps installed in the South and Small Onego, Kondopoga and Petrozavodsk bays. Sample preparation has been carried out according to the standard Faegri-Iversen method. We have identified 29 palynomorphs: 13 arboreal and herbal, and 4 spores. After the conducted palynological research of the dispersed (sedimentation traps) and concentrated (surface bottom sediments) sedimentary matter of Lake Onego, it can be concluded that the composition and ratio of the main components of the surface spore-pollen spectra give an adequate idea of plant communities developed in the area of the lake shore and nearby territories. The concentration of accumulated pollen in the sediments depends on the type of sedimentation. The regional component of the pollen complex remains relatively stable in all studied areas in the lake water area. The existing differences are associated with the local characteristics of each study area. Taxa, which grow abundantly near the studied sampling points throughout the lake area, make a significant contribution to the aspect of the spore-pollen spectrum. The work is supported by the Russian Foundation for Basic Research No. 19-05-50014. The statistical analysis has been conducted at the expense of funds of the subsidy allocated to Kazan Federal University for the state assignment \#671-2020-0049 in the sphere of scientific activities and by the Kazan Federal University Strategic Academic Leadership Program. 


\title{
Assessment of microcrustacean (Crustacea, Cladocera) biodiversity based on surface sediment samples from the northern lake Neito-3 (Malto) (Yamalo-Nenets Autonomous Okrug, Russia)
}

\author{
Niyaz M. Nigmatullin, Aleksandr A. Eliseev, Larisa A. Frolova \\ ${ }^{1}$ Kazan Federal University, Kazan, Russia; niyaz.nigmatullin.1995@mail.ru
}

Paleoclimatic investigations allow us to clarify the study of the climate and environmental situation of particular regions and water objects in the past and to predict future changes, identify the development trends of the Earth's climate. Cladocerans are very promising for studying climate change risks owing to their inherently predictive nature. They are form a rich functional group of zooplankton in ecosystem modeling and distributed all over the world.

This study investigates Neito-3 (Malto; 70¹2'125" N 70²2'592" E), a thermokarst blue lake on the Yamal Peninsula, Neito-Seyakha area. It covers the vastest area (more than $200 \mathrm{~km}^{2}$ ) in the Neito lakes system and is the Yamal's second largest water body. The lake kettle has a round shape and extends $17.8 \mathrm{~km}$ from south to north, $16.5 \mathrm{~km}$ from west to east. The shoreline length totals $60 \mathrm{~km}$. Despite its large size, the lake is shallow: average depth less than $3 \mathrm{~m}$, maximum depth up to $21 \mathrm{~m}$.

The sediment core (total length $16 \mathrm{~cm}$ ) for paleoecological analysis was taken from the deepest area of the Lake Neito-3 as part of the summer research expedition in 2020. Each segment was used to investigate the subfossil cladoceran remains by A. Korhola and M. Rautio's method.

The paleoecological analysis of the sediment core taken from the lake revealed a low species diversity. A total of 17 cladoceran taxa were identified, many of them occurred as single individuals. Bosmina longirostris was a stable superdominant throughout the entire sediment core. Its abundance changed only insignificantly. No considerable changes were registered in the taxonomic composition of subfossil cladocerans. Minor changes were detected in the number of Bosmina (Eubosmina) longispina and Chydorus sphaericus, which may indicate some fluctuations in the water level and trophic status of the lake. The number of littoral taxa also changed - it decreased in the middle part of the sediment core. The Shannon-Weaver index based on the abundance and taxonomic diversity values was low, which is due to the dominance of a single species. The Pantle-Buck saprobity index demonstrated $\beta$-mesosaprobity of the lake. A study of microcrustacean biodiversity in lakes of the Pechora River delta based on the analysis of subfossil Cladocera, вот это вставить The analysis of subfossil cladocerans was supported by the Russian Science Foundation (project no. 20-17-00135). The fieldwork was funded by the subsidy allocated to Kazan Federal University for the state assignment no. 671-2020-0049 in the sphere of scientific activities, as well as by the Kazan Federal University Strategic Academic Leadership Program. 


\title{
The microcrustacean biodiversity in the lakes of the Pechora River Delta based on the analysis of subfossil Cladocera
}

\author{
Niyaz M. Nigmatullin, Gulnara R. Nigamatzyanova, Elvira A. Valieva, Larisa A. Frolova \\ Kazan Federal University, Kazan, Russia; niyaz.nigmatullin.1995@mail.ru
}

The microcrustaceans (including Cladocera and Copepoda) are a key group of organisms in various aquatic biosystems as the most abundant component of zooplankton and benthos. Therefore, they have been widely used for assessing the degree of environmental pollution. Furthermore, their remains in lake sediments shed light on the long-term ecological and climate change in the past.

Sampling of surface sediments for subsequent paleolimnological analysis was performed in 17 lakes of the Pechora River delta during the summer expedition to the Nenets State Nature Reserve. All samples were taken from the deepest areas of the studied lakes with the help of an Ekman-Burge dredge. Under the field conditions, various hydrochemical parameters of the lakes were measured. Samples for analysis of subfossil cladocerans were prepared according to A. Korhola and M. Rautio.

Based on the chemical composition of their waters, the studied lakes belong to the chloride class, sodium group II. Overall, they are characterized by shallow depths typical for this region, low mineralization and water hardness, and, on the contrary, high dissolved oxygen levels.

Cladoceran assemblages reconstructed from lake sediments offer a profound insight into the interaction between ecological and climate factors. As a result of our analysis, a complex of dominant cladoceran species was revealed, with B. songispina and C. sphaericus that were either less to more abundant depending on the lake depth. A total of 23 cladoceran taxa were identified. Among them, the family Chydorydae prevailed (65\% of the total number of taxa). In the case of the low-abundant species, an interesting finding is that Rhynchotalona latens, an extremely rare glacial relict species, was registered for the first time in this region of Russia.

The indices calculated with the help of the quantitative parameters observed for subfossil cladocerans suggest that the studied lakes can be characterized as moderately polluted. The calculated values of the Czekanowski-Sorensen index point to the high similarity between the lakes under consideration on the level of species composition. The obtained values of the Pielou index show that cladoceran taxa are relatively evenly distributed within the assemblages. A study of microcrustacean biodiversity in lakes of the Pechora River delta based on the analysis of subfossil Cladocera, вот это вставить The analysis of subfossil cladocerans was supported by the Russian Science Foundation (project no. 20-17-00135). The fieldwork was funded by the subsidy allocated to Kazan Federal University for the state assignment no. 671-2020-0049 in the sphere of scientific activities, as well as by the Kazan Federal University Strategic Academic Leadership Program. 


\title{
The sources of terrigenous and volcanic ash material in the Middle Volgian (Jurassic) deposits of the eastern part of the Russian Platform
}

\author{
Konstantin I. Nikashin, Svetlana O. Zorina \\ Kazan Federal University, Kazan, Russia; kostya97@inbox.ru
}

The Middle Volgian (Upper Jurassic) bituminous shales of the eastern part of the Russian Platform have been attracting the attention of researchers for many years not only as an oil shale source but as a reflection of the Late Jurassic oceanic anoxic event as well. At the same time, the number of papers, devoted to the provenance analysis of these deposits and to the sources of pyroclastic material they contain, is still limited. The purpose of this research is to identify the sources of terrigenous and pyroclastic material in the epeiric sea of the eastern part of the Russian Platform in the Middle Volgian. In order to achieve this aim nine samples of the Volgian mudrocks, black shales, and sandstones from the Tatar Shatrashany borehole section and Gorodischi outcrop have been investigated using the mineralogical, ICP-MS, XRD, electron microscopy, and Raman spectroscopy analyses.

Various associations of accessory minerals of varying degrees of roundness have been identified in all studied samples. It points to the input of terrigenous material from the mixed source. The Paleozoic clastic deposits of the Volga-Ural and Voronezh Uplifts, igneous and metamorphic rocks of the Voronezh crystalline massive, Ural fold region, and Baltic Shield are regarded as most likely sources.

The morphology of detrital zircons reveals their association with felsic alkaline rocks. Presumably, these zircons were derived from the alkaline granites of the Pavlovsk intrusive complex, occurring within the Voronezh crystalline massive. It turned out that the chondritenormalized rare-earth element patterns of the Pavlovsk granites are very close to those of the Middle Volgian deposits.

Volcanic glasses and "camouflaged" pyroclastic material (heulandite, smectite, mixed-layer mineral) are found in mudrocks and black shales studied. The value of both smectite and mixedlayer mineral varies from 20 to $27 \%$ throughout the section, whereas the amount of heulandite reaches $25 \%$ in the Promzino black shales. The Raman spectroscopy analysis shows the intermediate-acid composition of the volcanic glasses, extracted from the Promzino Formation. Taking into account the paleogeographic situation in the latest Jurassic, volcanic arcs of the North Tethys (Transcaucasian and Sanandaj-Sirjan Arcs) and High Altitude Large Igneous Province are considered to be the major sources of the pyroclastic material. 


\title{
About the age of the Kygyltasian fossil flora from the Upper Paleozoic of Verkhoyanie, North-Eastern Russia
}

\author{
Lyubov G. Porokhovnichenko', Ruslan V. Kutygin², Afanasiy N. Kilyasov² \\ ${ }^{1}$ Tomsk State University, Tomsk, Russia; plg@t-sk.ru \\ 2Diamond and Precious Metal Geology Institute, Yakutsk, Russia
}

The Kygyltasian Regional Stage is widespread throughout the Verkhoyanie, where it reflects a large transgressive-regressive cycle of the Verkhoyanian terrigenous sedimentation. Over the years, a huge amount of material has been accumulated on biostratigraphic division, facies features, and paleontological characteristics of this large stratigraphic unit, but its age is still debatable. The main fossils in the upper part of the Kygyltasian Regional Stage are higher plants, the remains of which were studied in the last century using outdated taxonomy. This study was devoted to revision of the collection of fossil plants from the type locality of the Kygyltasian Regional Stage (Western Verkhoyanie) in order to clarify the taxonomic composition and the age of the Upper Kygyltasian floristic association. The dominant cordaite leaves in the association were studied using morphological and microstructural methods. This made it possible to clarify the previous paleontological definitions of the genus Noeggerathiopsis and bring them in line with modern taxonomy.

The species Noeggerathiopsis heteroclitus Tolstych and N. khorokytica Tolstych were validated for type specimens. The following species have been identified from the Upper Kygyltas Subformation of the Levy Khorokyt section: Cordaites heteroclitus (Tolstych), C. cf. neuburgae Gluchova, C. cf. zalesskyi Durante, C. krychtofovichii (Radczenko), Cordaites? khorokytica (Tolstych), Cordaites sp. 1, Cordaites sp. 2, Cordaites sp. 3, Cordaites sp. 4, Rufloria (Praerufloria) ex gr. theodorii (Tschirkova et Zalessky) S. Meyen, Samaropsis skokii Neuburg, S. cf. pauxilla Zalessky, S. aff. pumila Suchov, S. aff. auriculata Neuburg, Cordaicarpus baranovii Suchov, Crassinervia sp., Astrogaussia sp., Sphenophyllum cf. thonii Mahr, Sphenophyllum? sp., Sphenopteris sp., Paracalamites sp.

The results of the study made it possible to compare the Upper Kygyltasian floristic association of the Western Verkhoyanie with floristic associations of the Alykaeva Formation (Kuzbass) and the Upper Kata Subformation (Tunguska basin). From the above, the Late Carboniferous age of the upper part of the Kygyltasian Regional Stage follows. The data obtained are in good agreement with the correlation of the Verkhoyanian Carboniferous-Permian deposits for marine invertebrates. 


\title{
Chromite sandy sediments (Kazanian, Middle Permian) of the Southern Pre-Urals
}

\author{
Ildar R. Rakhimov \\ Institute of Geology, UFRC RAS, Ufa, Russia; rigel92@mail.ru
}

The Permian sediments are widespread in the East European Platform. The eastern margin of the platform, including the Southern Pre-Urals, is marked by abundant carbonate-terrigenous sediments of the Kazanian stage correlated with the Late Roadian and Wordian stages in SCGS. A chromite paleoplacer called the Sabantuy chromite occurrence was discovered earlier in the Kazanian stage section near the Fedorovka settlement, $200 \mathrm{~km}$ south-south-west of the Ufa city in the Republic of Bashkortostan. The $\mathrm{Cr}_{2} \mathrm{O}_{3}$ content in sandstones is up to 15-17 wt. \%. The ore bed in the Sabantuy occurrence with interlayers of chromite sandstones is $0.9-1 \mathrm{~m}$ thick. The latest studies show the following prospected dimensions of the Sabantuy placer: $330 \mathrm{~m}$ min length, $50 \mathrm{~m}$ min width. Minimal forecast resources of the chromite ore reserves with the average $\mathrm{Cr}_{2} \mathrm{O}_{3}$ content of 11 wt. \% was estimated as $16,000 \mathrm{~m}^{3}$.

In 2021, I described 22 sections with the general thickness of over $300 \mathrm{~m}$ in detail. Interlayers of massive chromite sandstones were discovered in seven other sections of chromitegravel sediments in the target area. The most representative sections are the "Akbulat", "Sukhoy Izyak" and "Kiryushkino". In these sections, chromite interlayers occur above, below or among gravel-pebble sediments in sandstone series. Chromite interlayers amount to 10-12; they show a minor thickness of only 1-3 mm, rarely up to $5 \mathrm{~mm}$. These sections differ in specific lithological diversity of their rocks, with the thickness of certain series similar in granulometric and structuraltextural signatures of the rocks. The coquina horizons (sandstones rich in fragments of brachyopods), sandstones with coaly and ferruginated plant debris, as well as prints of stalks and leaves of plants were discovered in each section. Two chromite-bearing horizons as thick as $0.3 \mathrm{~m}$ (upper) and $0.1 \mathrm{~m}$ were identified in the "Kiryushkino" section above the gravel-pebble series. In the "Sukhoy Izyak" section, the chromite-bearing horizon only $1 \mathrm{~cm}$ thick occurs in a thin (15-20 $\mathrm{cm}$ ) sandstone lens among gravel-pebble sediments. In the "Akbulat" section, an up to $10 \mathrm{~cm}$-thick chromite-bearing horizon occurs in a series of fine-grained sandstones well below gravel-pebble rocks.

Chromite sandstones occur in cross-bedded sediments, rapidly pinching our laterally. Some parts of the sections composed of unidirectional slanting series of sandy and gravel-pebble rocks correspond with alluvial sediments. Steep incline angles of the slanting series, i.e. up to $35^{\circ}$, are typical of fluvial deposits. Presumably, the chromite clastic material was removed from ophiolite and volcanogenic complexes in the Southern Urals specifically by river flows. In this case, the Sabantuy chromite-richest placer could be formed in delta settings. This is witnessed by finer terrigenous material from the section area with the chromite mineralization and wave-cut ripple marks in sediments.

The Riphean sedimentary-metamorphic complexes of the Bashkirian Meganticlinorium in the western part of the Southern Urals are considered the main source for the studied sediments. Notably, new data clearly indicate that chromite-bearing ultrabasic-basic complexes were principal sources of detrital material in certain timespans. Chromite sandstone interlayers can be used for stratigraphic subdivision and geological correlation for the rheional stratigraphic scale. 


\section{The Permian coal formation of the Pechora basin}

Nadezhda N. Ryabinkina, Olga S. Kotik, Olga V. Valyaeva, Sergey V. Ryabinkin Institute of Geology of Komi Science Centre of the Ural Branch of the Russian Academy of Sciences, Syktyvkar, Russia; nnryabinkina@gmail.com

The Pechora coal basin is located in the northeast of the European part of Russia within the Komi Republic and the Nenets National District of the Arkhangelsk Region. The basin is situated within Permian industrial coal formation and a part of a larger Timan-Pechora sedimentary basin. The coal deposits is traced up to the waters of the Pechora and Kara seas. The current area of distribution of the Permian coal formation is more than 130 thousand $\mathrm{km}^{2}$.

The Permian system was identified in 1841 by the British geologist Roderick Murchison near the city of Perm. The study of the coal formation of the Pechora basin begins in 1837.

The first stage, until 1917, was connected with the first information about the geology and coal content. The second stage, from 1917 until 1930, marked a systematic geological survey and discovery of industrial deposits. The third stage - from 1931 to the present - is a wide and deep development of research in the basin, a large volume of prospecting and exploration, as well as the industrial development of coal deposits.

The thickness of the Permian coal formation varies from $0.2-1.0 \mathrm{~km}$ in the west up to 5.5 $\mathrm{km}$ in the foredeep. Up to 270 coal seams and interlayers are known here. Westward their number is reduced to 1-3. Deposits of high-quality coking coal in the Pechora Basin are of the greatest economic importance for supporting the social and economic development of the Russian Arctic.

The study of coal deposits in the Arctic region provides important geological information for underexplored shelf areas during the reconstruction of facies and thermobaric conditions, which is important for geological exploration for oil and gas.

In this regard, the problem of extraction and utilization of coal mine methane is very urgent. Besides the regional coals are suitable for technological processing to produce synthetic liquid fuel, synthesis gas, and various components for the production of electrode products for metallurgy. 


\section{Geology and geochemistry of organic matter of the Lower Carboniferous deposits of the north of the Kolva Megaswell of the Timan-Pechora province}

Nadezhda N. Ryabinkina, Olga V. Valyaeva, Sergey V. Ryabinkin

Institute of Geology of Komi Science Centre of the Ural Branch of the Russian Academy of Sciences, Syktyvkar, Russia; nnryabinkina@gmail.com

The Kolva Megaswell $(300 \times 30-40 \mathrm{~km})$ is a part of the Pechora-Kolva aulacogen of the Timan-Pechora province (TPP). It is separated from neighboring structures by the West Kolva and East Kolva regional faults. The northern (land) part of the Kolva Megaswell includes the Kharyaga and Yareiyu walls. The sedimentary cover of the Megaswell is composed of deposits from the Early Paleozoic to the Mesozoic. The Yareiyu wall contains a number of local structures, different in configuration and size, among which the large North Yareiyu, Yuzhno-Khylchuyu, Yareiyu and other anticlinal structures with which are associated hydrocarbon deposits of the same name.

The facies environments of accumulation and diagenetic conditions of organic matter burial were very diverse, and this determined the peculiarities of the composition of dispersed organic matter (DOM) in the sediments of different-age oil and gas complexes (OGC).

As we know, the intensity of generation processes in the oil and gas complex is determined by the organic material $(\mathrm{OM})$ composition, its oil and gas source potential and the level of thermal maturity of rocks. Exactly the complex catagenetic zoning of the TPP sedimentary cover influenced the features of the thermal maturation of DOM and its vertical zoning.

Having considered the structure of the terrigenous-carbonate strata and the composition of $\mathrm{OM}$ of the rocks, we can distinguish a shallow-sea stagnant sedimentation regime for carbonate rocks and a more active hydrodynamic regime during the accumulation of clay and terrigenous bundles.

It was found that the OM of rocks accumulated in similar conditions of sedimentation, but differs in its composition. In addition, the data obtained indicate slight or moderate bacterial processing of the initial organic matter in the early diagenesis in sub-regenerative conditions of sedimentation of the initial organic matter. The rocks of the complex are in the "oil window" stage, which is favorable for the formation of liquid hydrocarbons.

The results of additional geochemical studies of rocks and bitumoids from the lower Carboniferous deposits of the north of the Kolva Megaswell showed that the initial OM accumulated in the coastal and marine environments. The maturity of organic matter corresponds to the beginning of the "oil window". 


\title{
Sedimentary structures from the Early Permian Tambach Sandstone at the Bromacker (Thuringian Forest basin, Germany)
}

\author{
Frank Scholze \\ Institute for Geoscience, Friedrich-Schiller-University Jena, Jena, Germany; frank.scholze@uni-jena.de
}

The Bromacker site, a well-known fossil lagerstätte located adjacent to the town TambachDietharz in Thuringia, represents an exceptional Central European occurrence of Early Permian tetrapod skeletons and tetrapod trace fossils in a continental depositional palaeoenvironment. At present, the site is exposed through a sandstone quarry, a scientific excavation, and scientific drill cores, as well as nearby abandoned quarries. Previous palaeontologic studies at the Bromacker established an important correlation between tetrapod taxa and certain types of tetrapod trace fossils. Invertebrates (e.g., arthropods, hydromedusa) and well-preserved but partially still enigmatic (invertebrate?) burrows (e.g., Tambia spiralis) have been recorded as well, whereas plant fossils occur frequently but are often only poorly preserved. All fossil faunal and floral elements from the Bromacker belong lithostratigraphically to the Tambach Sandstone (the intermediate member of the Tambach Formation, Rotliegend Group). In agreement to previous studies, the depositional environment at the Bromacker site can be interpreted as an intramontane upland setting that is marked by predominant terrestrial, semi-arid conditions with temporary wet interruptions. The diverse lithologies of the Tambach Sandstone Member include either horizontal to slightly cross-bedded or massive fine- to medium-grained sandstones, cross-bedded, in parts coarse-grained to conglomeratic, sandstones, partially laminated clay- to siltstone, massive siltstones, and rooted palaeosoils composed of siltstone to fine sandy siltstone. All these lithologies show reddish rock colours; fine greenish to greyish colour muddling occurs occasionally. Deposits of the Tambach Sandstone Member are discussed as resulting from transport and sedimentation processes trough fluvial channels and sheet floods on alluvial plains as well as mud flows. Most frequent sedimentary structures include desiccation cracks and rain drop imprints of various sizes. Load casts, scour marks, ripples, intraformational clayey rip-up clasts, and water level marks are frequent. A scratch circle occurring on a sandstone block in the Bromacker quarry section was newly recorded during current fieldworks. In conclusion, a detailed preservation of the majority of sedimentary structures depends on the occurrence of thin claystone- to fine siltstone-laminae of fluvial sheet flood deposits, whereas massive siltstones of mud flow deposits are more perspective for a preservation of fossils. The preservation and diversity of both sedimentary structures and fossils makes the Bromacker a very important site for studying Early Permian pure continental deposits in Central Europe. 


\title{
Designing the development of productive deposits of a gas condensate field with a complex geological structure
}

\author{
Rustam R. Shaidullin \\ Kazan Federal University, Kazan, Russia; like.rustam95@gmail.com
}

The problem of designing the development of gas fields is one of the most urgent in the oil and gas industry, since at this stage decisions are made that determine the success of field development, which is especially important in connection with the depletion of gas reserves in relatively simple reservoir rocks.

The purpose of this work is an attempt to design the development of gas condensate productive formations of an oil and gas condensate field. The work was carried out on the basis of the available geological and geophysical data, field and laboratory studies.

The tasks of the work were to identify production facilities, select the location and grid of production wells, draw up technological development schedules and calculate economic indicators.

The object of research is the productive terrigenous deposits of one of the gas condensate fields in Western Siberia. Cenomanian reservoir rocks have a complex geological structure, characterized by a complex behavior of filtration-volumetric properties and thermodynamic parameters.

In the course of the study, the results of the field studies were carried out, as well as the productivity indicators of the operating well stock were summarized. Digital geological models, built on the basis of data from prospecting and exploration and operational work, were analyzed. The experience of designing the development of overlying strata with a similar geological structure was generalized. An analysis of design errors and determination of their causes was carried out to identify "weak" points and factors that were not taken into account in the design. There were designed 2 options for the development of productive deposits with different technological and economic indicators. 


\section{New non-ammonoid cephalopods of the Early Permian Shakh-Tau reef}

Alexander Yu. Shchedukhin

Borissiak Paleontological Institute, Russian Academy of Sciences, Moscow, Russia; $\underline{d}$ alsch2017@mail.ru

A study of recent collections (2019-2021) of Early Permian non-ammonoid cephalopods from the Shakh-Tau quarry (Bashkortostan) made it possible to identify several forms that had not been encountered before. From this locality, two rich cephalopod assemblages have already been described - the border Asselian-Sakmarian, represented by the orders Nautilida and ?Oncocerida, and the Upper Artinskian, with the orders Nautilida, Pseudorthocerida and Bactritida. Currently, in the Asselian-Sakmarian collection, orthoconic cephalopods of the order Pseudorthocerida have been identified for the first time: Uralorthoceras sp. (1 sample) and Kionoceras serenum Shimansky (3 samples). The latter is well defined by its characteristic sculpture in the form of clear longitudinal ribs. Uralorthoceras sp. could not be identified due to its poor preservation. Several new forms from the order Nautilida have been identified. Gzheloceras uralense Ruzhencev et Shimansky, 1954, has been identified as a new species for Shakh-Tau. The characteristic shell sculpture, the shape of the septal line, the cross section, and the whorl width make it possible to assign the studied shell to this species. Previously Gzh. uralense was known only from the Baigendzhinian Regional Substage of the Artinskian Stage of Kazakhstan, and the Zhil-Tau mountain.

Incidentally, two new forms of the generic rank were discovered, most likely belonging to the Rhiphaeoceratidae family. Genus A has an atypical narrow umbilical perforation, which strongly distinguishes it from the known Rhiphaeoceratids. Genus B, also classified as Rhyphaeoceratidae on the basis of the sculpture and shape of the suture line, is distinguished by uniformly widening whorls and ribs located only along the umbilical margin, and not along the entire lateral surface of the shell.

Large shells of two nautilids with a complex lobed suture line and varying degrees of involute are of great interest. In appearance, they particularly resemble representatives of the predominantly Triassic families - Clydonautilidae and Grypoceratidae. They differ distinctively from each other - in the putative representative of Clydonautilidae, the suture line is strongly dissected, with a very deep dorsal lobe. The shell is strongly involute, with flattened sides and a distinct ventro-lateral bend in the adult whorls. The shell attributed to the Grypoceratidae, is much less involute, with almost flat lateral sides and a very sharp ventral edge forming a keel. The suture line in this species is not so strongly dissected; at the ventro-lateral bend it forms sharp and distinct saddles passing into the lateral lobe, and at the umbilical bend there is a small saddle and, apparently, a deep dorsal lobe. It is possible to attribute both new forms to the new Permian nautilid family. This issue requires further detailed study.

The discovery of such a large number of new forms of high taxonomic rank confirms the uniqueness of the Asselian-Sakmarian reef cephalopod complex Shakh-Tau and its great potential for studying the Permian nautiloids in the future. 


\section{Evidence for soft-bodied organisms and invertebrate soft tissues in mudstones of the Timanian Horizon (Devonian, Frasnian) of the Southern Tatarian Dome (East European Platform)}

Vladimir V. Silantiev, Dinara N. Miftakhutdinova, Veronika V. Zharinova, Milyausha N. Urazaeva

Kazan Federal University, Kazan, Russia; vsilnt@gmail.com

The Timanian Horizon is the terminal part of the Devonian terrigenous complex within the Southern Tatarian Dome (STD). It is represented by a succession of carbonates and siliciclastics, which includes the "upper limestone" marker bed. Mudstone, siltstone and sandstone layers with marine fauna and/or trace fossils (ichnofossils) of marine organisms are located below and above the "upper limestone". The Timanian horizon is conventionally correlated with the beginning of marine transgression and the lower boundary of the Frasnian Stage in the Volga-Ural Region (Fortunatova et al., 2013).

In 2021, a unique burial (Konservat-Lagerstätte) of soft-bodied fauna, including impressions of polychaetes, problematic remains, and soft tissues of inarticulate lingulid brachiopods was discovered during the study of a drill core from a series of wells in mudstones immediately above the "upper limestone". In addition to these remains, this level includes impressions (!) of conodonts, ostracod shells, and shells of marine bivalves with preserved primary shell microstructure. Shells of the conchostracan genus Glyptoasmussia, traditionally considered to be a freshwater inhabitant (Novojilov, 1961), were also found here. It is important to note that conchostracans are also known from marine Devonian sediments in Belgium (Webb, 1979).

Pyrite framboids are often observed on the claystone bedding planes that yielded the remains of soft-bodied fauna. They indicate anoxic sediment (and bottom water) conditions and basin depths below the normal (and possibly storm) wave base or closed lagoon conditions.

Preservation of soft-bodied fauna is possible in an anoxic environment with rapid burial and conservation of the sediment.

The preservation of primarily phosphatic conodonts in the form of impressions indicates specific physicochemical conditions of diagenesis, under which the behavior of soluble reactive phosphorus concentrations was probably controlled by the calcium ion content at $\mathrm{Eh}<0 \mathrm{mV}$ and $\mathrm{pH}=5 / 6$ (e.g., Moore \& Reddy, 1994). It is possible that the acidic conditions in the sediment occurred due to the entry of organic acids.

The interval with remains of soft-bodied fauna has been traced within several areas of the STD and may serve as a regional macro-marker of the Timanian Horizon.

The work is supported by the subsidy allocated to Kazan Federal University for the state assignment \# 671-2020-0049 in the sphere of scientific activities.

\section{REFERENCES}

Fortunatova N.K. Stroenie devonskogo terrigennogo kompleksa i polozhenie granitsy srednego i verkhnego devona na zapade Tatarstana / N.K. Fortunatova, E.L. Zaytseva, O.A. Kartseva // Bull. MOIP Otd. Geol. - 2013. - V. 886 iss. 2. - P. 22-49 (In Russian).

Novojilov N.I. Dvustvorchatye listonogie Devona / N.I. Novojilov // Trudy Paleontologicheskogo instituta. - 1961. - LXXX|ю - P. 1-182 (In Russian). 


\title{
Outline of the history of the Permian System in Russia and Central Europe
}

\author{
Vladimir V. Silantiev ${ }^{1}$, Andrey G. Sennikov², Valery K. Golubev ${ }^{1,2}$, Joerg W. Schneider ${ }^{1,3}$ \\ ${ }^{1}$ Kazan Federal University, Institute of Geology and Petroleum Technologies, Kremlyovskaya Street 18, \\ Kazan, Russia \\ ${ }^{2}$ Borissiak Paleontological Institute, Profsoyuznaya Street 123, Moscow, Russia \\ ${ }^{3}$ Technical University Bergakademie Freiberg, Institut für Geologie, Bernhard-von-Cotta-Straße 2, D-09596 \\ Freiberg, Germany
}

On invitation by Tsar Nicholas I., the Scottish geologist Sir Roderick Impey Murchison visited Russia in 1840 and 1841 together with the French palaeontologist Édouard de Verneuil for a study of the geology and stratigraphy of the Russian Platform and the Ural Mountains. The expedition was guided by the Baltic-German Russian geologist and zoologist Alexander Graf von Keyserling. During the first part of the expedition from Moscow to Vladimir, Kazan, and Perm, they observed widespread deposits of red-coloured conglomerates, sandstones, and siltstones, intercalated with marine carbonate rocks, similar to the Rotliegend and Zechstein of Germany but of still unknown age. In 1841, Murchison together with de Verneuil published a first report on the results of the expedition, introducing a formal name for the Permian system. A more detailed and comprehensive description and definition of the Permian system was published by Murchison et al. (1845) in their well-known major work entitled "The Geology of Russia in Europe and the Ural Mountains". Figure 1 shows the approximate range of the Permian system as intended by Murchison in the 1840s.

\begin{tabular}{|c|c|c|}
\hline $\begin{array}{l}\text { Stratigraphic units of the } \\
\text { New Red Sandstone of England } \\
\text { according to Sedgwick (1829) }\end{array}$ & $\begin{array}{l}\text { Traditional stratigraphic units } \\
\text { of the German basins } \\
\text { since } 1700 \text { s }\end{array}$ & $\begin{array}{l}\text { Approximate Murchison's intention } \\
\text { in dividing the Permian and Triassic } \\
\text { (according to Murchison et al. 1845) }\end{array}$ \\
\hline Upper red marl and gypsum & Keuper Group & \multirow{3}{*}{ TRIAS } \\
\hline unconformity & Muschelkalk & \\
\hline Upper red sandstone & Buntsandstein & \\
\hline Grey thin-bedded limestone & \multirow{5}{*}{ Zechstein } & \multirow{6}{*}{ 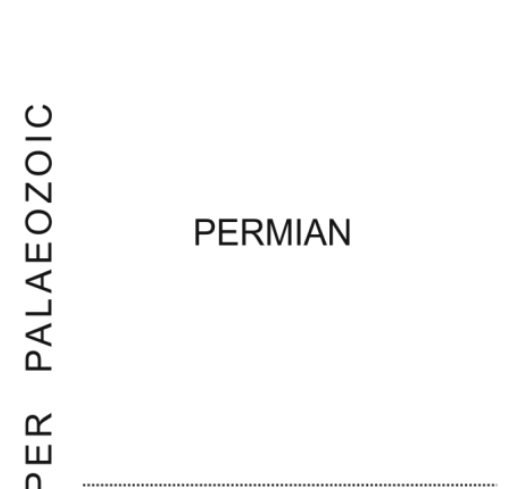 } \\
\hline Lower red marl and gypsum & & \\
\hline Yellow Magnesian Limestone & & \\
\hline $\begin{array}{l}\text { Compact and shelly limestone } \\
\text { and variegated marls }\end{array}$ & & \\
\hline Marl Slate and compact limestone & & \\
\hline Lower red sandstone & Rotliegend & \\
\hline Coal Measures & Steinkohlengebirge & CARBONIFEROUS \\
\hline
\end{tabular}

Fig. 1. Approximate correlation of Murchison's Permian with already existent German and British stratigraphic units. Modified from Benton and Sennikov (2021) 
One might conclude that the idea of the Permian system was already hanging in the air, and Murchison, with his scientific talent and broad knowledge, brilliantly crystallized it through his expeditions and scientific work. The fast establishment of the Permian System by Murchison (1841) is primary based on the foregoing work of Russian geologists, many of which had German roots, e.g. Alexander Graf von Keyserling, Friedrich Wangenheim von Qualen, Gotthelf (Grigory Ivanovich) Fischer von Waldheim. The Russian geologists have accumulated a huge amount of knowledge already before Murchison appeared in Russia and helped him during his expeditions with all available data, but never disputed his priority. Even later, Russian geologists recognized that for many decades the book by Murchison et al. (1845) remained the best summary on the Permian geology of European Russia.

The whole story of Murchison's expeditions in Russia, the support which he got from Russian government agencies and geologists, has recently been documented in comprehensive and well-illustrated historical overviews of the establishment of the Permian system in Russia by Sennikov (2020) and Benton and Sennikov (2021) based on detailed study of all available historical documents in the literature and in Russian archives.

Murchison's new stratigraphical term "Permian" was not accepted by leading WestEuropean geologists and stratigraphers of his time. The contrast between the early Permian continental red beds and the late Permian marine sediments, especially in Germany and England, led the French geologist M.J. Marcou (1859) to introducing the term „Dyas" for the "nouveau grès rouge en Europe, dans I'Amérique du Nord et dans 1'Inde". Interestingly, his idea was based on "Werner et ses élèves de l'élcole des mines de Freiberg” and on „Freiesleben, I'éleve de prédilection de Werner et l'ami intime de Buch, est le géologue qui a le premier décrit l'etage du zechstein ...". H. B. Geinitz $(1861,1862)$ adopted the idea of the Dyas and gave a more precise definition: „Der Name Dyas ... umfasst jenen Schichtencomplex, welcher zwischen der Steinkohlenformation und der Trias zur Entwicklung gelangt ist .... Er umfasst eine Zweiheit ... von eng miteinander verbundenen Gebirgsformationen, von denen die Zechsteinformation eine Meeresbildung ... ist, während das Rothliegende, im Wesentlichen ein Product von süssen Gewässern, mit den in seine Schichten eingreifenden Eruptivgesteinen, wenigstens theilweise als Parallelformation jener Meeresbildungen betrachtet werden muss.“ (Translation: "The name Dyas...comprises the complex of beds which are developed between the Anthracite Coal Formation and the Trias... It comprises a duality... of closely related rock formations, of which the Zechstein Formation is of marine origin ... while the Rothliegendes, essentially a product of fresh waters, with the igneous rocks penetrating into its strata, must be considered, in parts at least, as contemporaneous with these marine deposits.") The base of the Dyas has been defined by Geinitz (1861) as the base of grey conglomerates, resting on the Coal Measures sometimes with a disconformity. Ludwig in Geinitz' "Die Dyas in Russland" (1862) discussed the Permian in Russia based on his own observations in regard to the Dyas of M.J. Marcou.

But already in the early 20th century the term Dyas was forgotten. Interestingly, after the definition of the chronostratigraphic C/P (Gzhelian/Asselian) boundary in Russia, which is situated in the uppermost part of the European lithostratigraphical Coal Measures Group (e.g. Schneider 1992; Schneider et al. 2020), the term Dyas was re-introduced by the German Stratigraphical Commission as a lithostratigraphical Supergroup comprising the Rotliegend and the Zechstein groups based on the proposals of Schneider (1992, 2000, 2001).

Murchison considered the thick red-coloured continental succession intercalated with subordinate marine rocks to be the main element of the Permian in European Russia. Newer data indicate that this succession covers the interval from the Kungurian to the Lower Triassic. Largescale geological mapping carried out at the end of the nineteenth and particularly in the twentieth century allowed for clarifying the boundaries of the Permian system and subdividing it on a detailed 
scale (Fig. 2). Today, the Permian system of European Russia has a distinctly bipartite structure: its lower part consists mainly of thick marine deposits (Asselian-Kungurian), while the upper part is composed of predominantly red-coloured continental formations (Ufimian-Vyatkian).

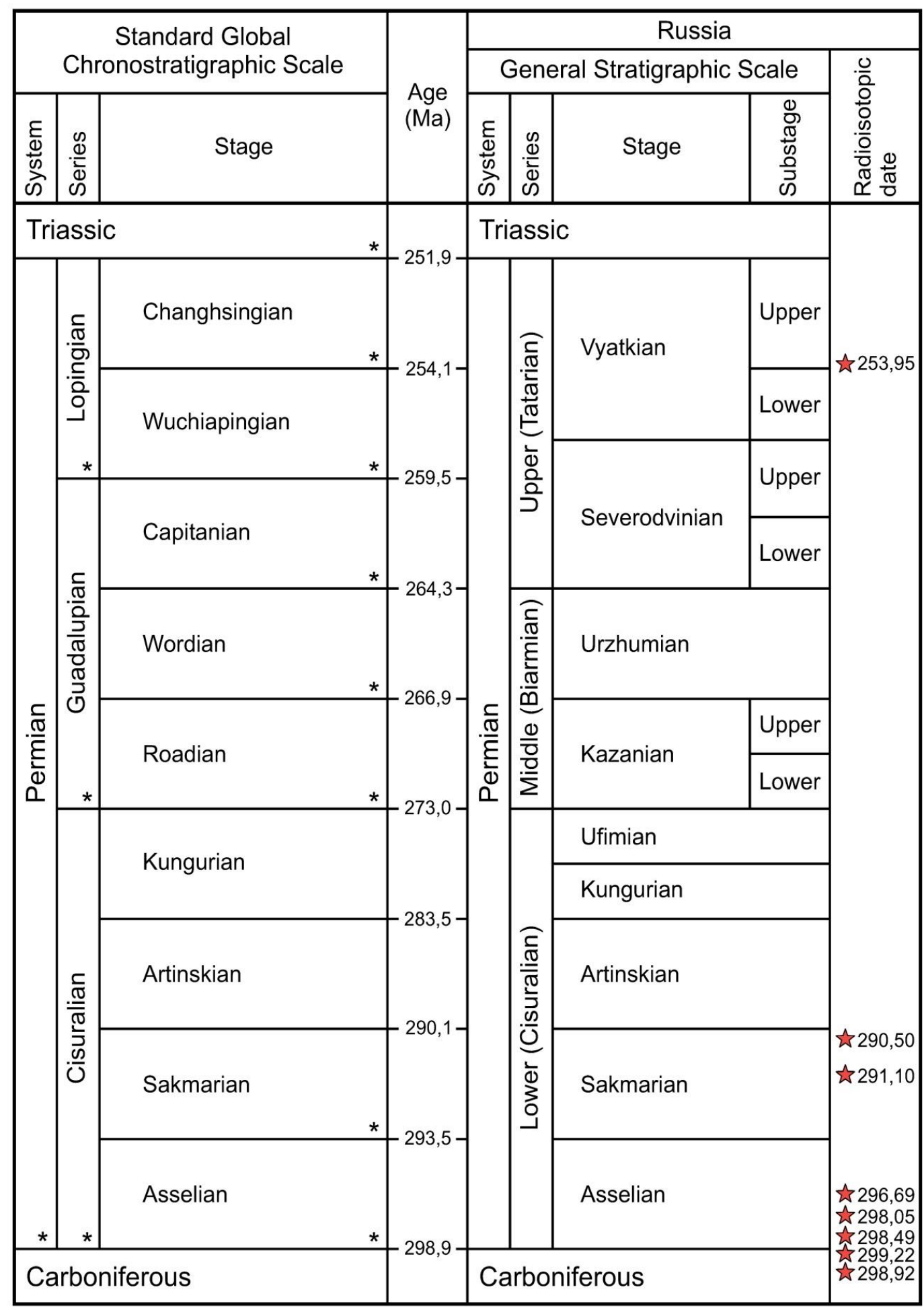

Fig. 2. Stratigraphic chart of the Permian System in European Russia. Standard Global Chronostratigraphic Scale and numerical ages for stage boundaries based on Cohen et al. (2013). Ratified GSSPs are indicated by black asterisks. General Stratigraphic Scale of Russia is given according to the 'Stratigraphic Code of Russia' (2006) and Schneider et al. (2020). Stratigraphic positions of the radioisotopic ages are indicated by red asterisks: the Vyatkian radioisotopic date is according to Davydov et al. (2020); the Asselian and Sakmarian radioisotopic dates are according to Chernykh et al. (2020) 
The Permian is the only one geological system defined in Russia. Our future task is to remember this and cherish the complicated history of its acceptance as well as to promote further research in the mixed marine-continental deposits of the Russian Platform, which are of highest importance for global correlations of Carboniferous, Permian, and Triassic deposits. Recently, a special issue of the journal Palaeoworld (2020) initiated by the Kazan-Freiberg research team after the 2018 Golovkinsky meeting assembled contributions of many international authors on these topics, including a state-of-the-art summary by 18 authors from all around the world in Schneider et al. (2020): Late Paleozoic-early Mesozoic continental biostratigraphy — Links to the Standard Global Chronostratigraphic Scale.

\section{REFERENCES}

Benton M.J. The naming of the Permian System / M.J. Benton, A.G. Sennikov // Journal of the Geological Society. - 2021. - 037. http://dx.doi.org/10.1144/jgs2021-037

Chernykh V.V. The Global Stratotype Section and Point (GSSP) for the base-Sakmarian Stage (Cisuralian, Lower Permian) / V.V. Chernykh, B.I. Chuvashov, S.-Z. Shen, C.M. Henderson, D.-X. Yuan, M.H. Stephenson // Episodes. - 2020. - V. 43, iss. 4. - P. 961-979.

Cohen K.M. The ICS International Chronostratigraphic Chart / K.M. Cohen, S.C. Finney, P.L. Gibbard, J.-X. Fan // Episodes. - 2020. - V. 36. - P. 199-204. (Updated: https://stratigraphy.org/lCSchart/ChronostratChart2021-07.pdf)

Davydov V.I. Radioisotopic and biostratigraphic constraints on the classical Middle-Upper Permian succession and tetrapod fauna of the Moscow syneclise, Russia / Davydov V.I., M.P. Arefiev, V.K. Golubev, E.V. Karasev, M.A. Naumcheva, M.D. Schmitz, V.V. Silantiev, V.V. Zharinova // Geology. - 2020. - V. 48, iss. 7. - P. 742-747. DOI: 10.1130/G47172.1

Geinitz H.B. Dyas oder die Zechsteinformation und das Rothliegende. Heft 1. Die animalischen Ueberreste der Dyas, 1861. - 130 p. - 23 pl.; Verlag Wilhelm Engelmann (Leipzig).

Geinitz H.B. Dyas oder die Zechsteinformation und das Rothliegende (Permische Formation zum Theil). Heft 2. Die Pflanzen der Dyas und geologisches, 1862. - 342 p. - 41 pl.; Verlag Wilhelm Engelmann (Leipzig).

Murchison R.I. Memoir on Russia / R.I. Murchison, E. de Verneuil // Proceedings of the Geological Society, London. - 1841. - V. 3. - P. 398-408.

Murchison R.I. A second geological survey of Russia in Europe / R.I. Murchison, E. de Verneuil // Proceedings of the Geological Society, London. - 1842. - V. 3. - P. 717-730.

Murchison R.I. On the Permian System as developed in Russia and other parts of Europe / R.I. Murchison, E. de Verneuil // Quarterly Journal of the Geological Society, London. - 1845. V. 1. - P. 81-87. https://doi.org/10.1144/GSL.JGS.1845.001.01.19

Murchison R.I. The Geology of Russia in Europe and the Ural Mountains / R.I. Murchison, E. de Verneuil, A. Keyserling. - 1845. - 2 vols, vol 1, John Murray, London 2, Bertrand, Paris.

Schneider J. Zum Problem der "Stefan"/Rotliegend- und der Karbon/Perm-Grenze. Perm-Trias Subkommission der DUGW / J. Schneider. Kurzreferate und Exkursionsführer, Aschersleben, 1992. - 5.

Schneider J.W. Geinitz and the Dyas / J.W. Schneider // Schriften des Staatlichen Museum für Mineralogie und Geologie zu Dresden. - 2000. - V. 11. - P. 107-108.

Schneider J.W. Rotliegendstratigraphie - Prinzipien und Probleme. Beiträge zur Geologie von Thüringen / J.W. Schneider // Neue Folge. - 2001 - - V. 8. - P. 7-42.

Schneider J.W. Late Paleozoic-early Mesozoic continental biostratigraphy - Links to the Standard Global Chronostratigraphic Scale / J.W. Schneider, S.G. Lucas, F. Scholze, S. Voigt, L. Marchetti, H. Klein, S. Opluštil, R. Werneburg, V.K. Golubev, J.E. Barrick, T. Nemyrovska, A. 
Ronchi, M.O. Day, V.V. Silantiev, R. Rößler, H. Saber, U. Linnemann, V. Zharinova, S.-Z. Shen // Palaeoworld. - 2020. - V. 29, iss. 2. - P. 186-238.

Sedgwick $A$. On the geological relations and internal structure of the Magnesian Limestone, and the lower portions of the New Red Sandstone Series in their range through Nottinghamshire, Derbyshire, Yorkshire and Durham, to the southern extremity of Northumberland / A. Sedgwick // Transactions of the Geological Society, London. - 1829. - V. 2. - P. 37-124. https://doi.org/10.1144/transgslb.3.1.37

Sennikov A.G. Ekspeditsija R I Murchisona v gorode Vjazniki / A.G. Sennikov // Priroda. - 2020. V. 10. - P. 55-69. DOI:10.7868/S0032874X20100075 (In Russian).

Stratigraphic Code of Russia. St. Petersburg: VSEGEI Press, 2019. - 93 p. (in Russian). 


\title{
The Permian-Triassic non-marine bivalves from the volcanic succession of the Siberian Flood-Basalt Province
}

\author{
Vladimir V. Silantiev ${ }^{1}$, Miyausha N. Urazaeva1 ${ }^{1}$ Ilja Kogan ${ }^{1,2}$ \\ ${ }^{1}$ Kazan Federal University, Kazan, Russia; vsilant@gmail.com \\ ${ }^{2}$ TU Bergakademie Freiberg, Freiberg, Germany
}

The mass extinction at the Permian-Triassic boundary drastically changed the spatial distribution of non-marine bivalves - the typical inhabitants of aquatic continental environments such as lakes, swamps and rivers.

While in the Late Permian, non-marine bivalves were widespread in almost all continental sedimentary basins of Pangaea (Fig. 1A), their Early Triassic occurrences are mainly restricted to the Volcanic Succession (or so-called Tuff-lava strata) of the Siberian Flood-Basalt Province (Fig. 1B). Outside this area, finding localities of non-marine bivalves are sparse and generally confined to later Triassic sediments (Yates et al., 2012).

The Volcanic Succession (up to 3,500-4,000 m thick) consists of an alternation of lava packets and flows (over 200) and thin tuffs, tuffites and sedimentary units. The effusive facies accounts for more than 9/10 of the Volcanic Succession (Czamanske, Gurevitsch et al., 1998). Trap volcanism in Siberia is considered to be the main trigger of the Permo-Triassic extinction (Sobolev et al., 2011 and many others).

The Permian-Triassic boundary is traditionally placed in the lower part of the Volcanic Succession. The basal part of the Volcanic Succession (Syradasay, Shaitan, Ivakin Formations and their analogues) is attributed to the terminal Permian, while the overlying sediments are attributed to the Triassic.

Although sedimentary rocks are subordinate in the Volcanic Succession, they contain a diverse complex of organic remains including microconchids, conchostracans, ostracods, insects, bivalves, fishes, amphibians, macroflora and miospores (Shcherbakov et al., 2021). Increased biodiversity in the Early Triassic of the Siberian Flood-Basalt Province raises questions about the connection between trap volcanism and extinction at the Permian-Triassic boundary (Sadovnikov, 2016, and others).

Non-marine bivalves occur throughout the lower $1100 \mathrm{~m}$ of the Volcanic Succession (Czamanske, Gurevitsch et al., 1998). Lists of Lower Triassic non-marine bivalves, compiled based on earlier publications and reports, include representatives of Triassic, Permian and Jurassic genera. All these genera have similar smooth-walled unionid, subtriangular and circular shell outlines.

Among the Triassic genera, Utschamiella Ragozin, 1937 (Early and Middle Triassic) is the most frequently mentioned. This genus is widespread in the Tunguska and Kuznetsk Basins, and at the eastern slope of the Urals. Microstructural characteristics allow distinguishing this genus from externally similar Permian and Jurassic morphotypes (Silantiev et al., 2020).

Permian genera whose species are indicated from the Early Triassic (Lobanova et al, 1969; Kolesnikov, 1980 et al.) include Palaeanodonta Amalitzky, $1895\left(\mathrm{P}_{1-3}\right)$; Microdontella Lebedev, 1944 $\left(\mathrm{P}_{2-3}\right)$; Abiella Ragozin, $1933\left(\mathrm{P}_{1}\right)$; Concinella Betekhtina, $1966\left(\mathrm{P}_{2-3}\right)$; Palaeomutela Amalitzky, 1892 $\left(P_{1-3}\right)$; and Oligodontella $\left(P_{3}\right)$ Gusev, 1963. These identifications are in need of revision, since they were made exclusively on the basis of external outlines and have not been confirmed by internal shell features nor by shell microstructure.

The most interesting question is how non-marine bivalves and their supposed fish hosts migrated to the ephemeral lake environments that emerged on the cooled lava flow fields. 
Hypothetical continental freshwater routes represented by a system of lakes and river systems may be supposed. Evidence of such routes has not survived in the geological record.

Future special studies may shed light on the questions raised in this contribution.
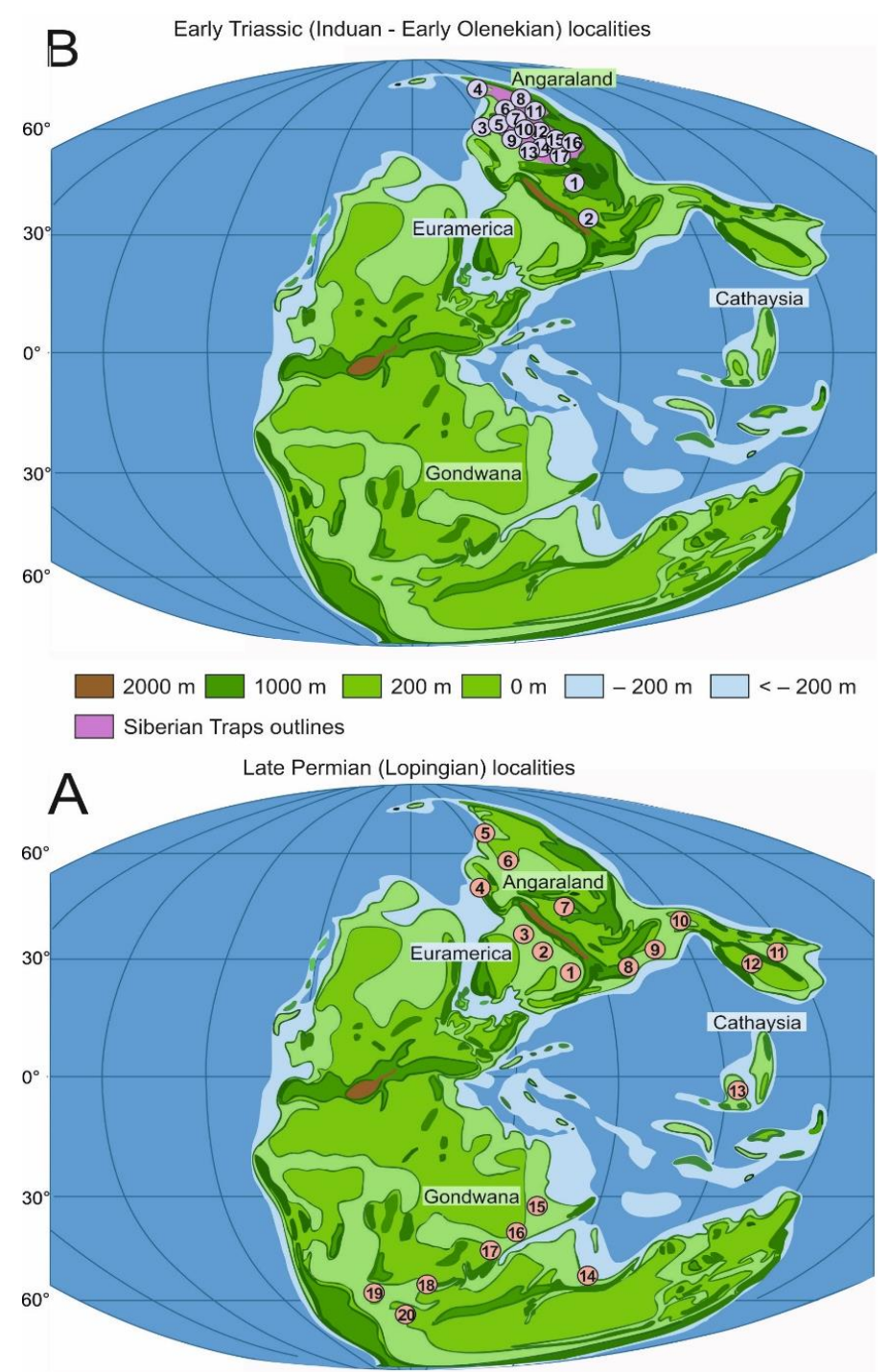

Fig. 1. Main finding localities of Late Permian (Lopingian) (A) and Early Triassic (B) nonmarine bivalves; paleogeographic reconstruction of the Late Permian (255 Ma) (after Ziegler et al., 1997).

(A) Main finding localities of Late Permian (Lopingian) nonmarine bivalves (after Silantiev, 2018): Euramerican Realm: (1-3) East European Platform: (1) Caspian Basin; (2) Volga-Ural Basin; (3) DvinaMezen Basin; Angarian Realm: (4) Pechora Basin; (5) Taimyr; (6) Tunguska Basin; (7) Kuznetsk Basin; (8) Tarim Basin; (9) Junggar Basin; (10) Turpan Basin; (11) northeastern China, Inner MongoliaHinggan; Cathaysian Realm: (12) Qiliang Shan Folded Belt; (13) southern China, Yunnan Province; Gondwanan Realm: (14) Raniganj and Jharia Basins; (15) Kenya; (16) Tanzania; (17) Malawi; (18) Zambia and Zimbabwe; (19) South Africa, Main Karroo Basin; (20) Antarctica, Ohio Range.

(B) Main finding localities of Early Triassic nonmarine bivalves: Angarian Realm: (1) Kuznetsk Basin; (2) Eastern slope of the Urals, Chelyabinsk coal basin; (3-4) Taimyr, Byrranga Area; (3) Dikson Area; (4) Tsvetkov Cape - Nordvik Area; (5-6) Norilsk-Turukhan Region; (5) Norilsk Area and north part of Khantayka - Nizhnyaya Tunguska Area; (6) Norilsk-Kharaelakh Area; (7-8) Anabar-Tunguska Region; (7) Kureika-Lama Area; (8) north of Ayan-Verkhniy Kotuy Area; (9-15) Tunguska Region; (9) LamaKhantaika Area; (10) western part of Kochechum-Tutonchana Area; (11) south of Ayan-Verkhniy Kotuy Area; (12) south of Kochechum-Tutonchana Area; $(13,14,15)$ Nizhnyaya Tunguska Area; (16) Lower Tunguska River and Vilyui River watershed; (17) Taimura River basin. 


\section{REFERENCES}

Czamanske G.K. Demise of the Siberian Plume: Paleogeographic and Paleotectonic Reconstruction from the Prevolcanic and Volcanic Record, North-Central Siberia / G.K. Czamanske, A.B. Gurevitch, V. Fedorenko, O. Simonov // International Geology Review, 1998. - V. 40, iss. 2. - P. 95-115. DOI: 10.1080/00206819809465200

Shcherbakov D.E. Disaster microconchids from the uppermost Permian and Lower Triassic lacustrine strata of the Cis-Urals and the Tunguska and Kuznetsk basins (Russia) / D.E. Shcherbakov, O. Vinn, A.Yu. Zhuravlev // Geological Magazine. - 2021. - P. 1-23. https://doi.org/10.1017/S0016756820001375

Silantiev V.V. Early Triassic Non-Marine Bivalves Utschamiella Ragozin, 1937 from the Kuznetsk Coal Basin: First Microstructural Data / V.V. Silantiev, J. Carter, M.N. Urazaeva, N.G. Nurgalieva, A. Nizamova // Proceedings 4th Kazan Golovkinsky Stratigraphic Meeting 2020 Sedimentary Earth Systems: Stratigraphy, Geochronology, Petroleum Resources (Kazan, Russian Federation, 26-30 October 2020). - 2020. - P. 248-255.

Sobolev S.V. Linking mantle plumes, large igneous provinces and environmental catastrophes / S.V. Sobolev, A.V. Sobolev, D.V. Kuzmin, N.A. Krivolutskaya, A.G. Petrunin, N.T. Arndt, V.A. Radko, Y.R. Vasiliev // Nature. - 2011. - V. 477, iss. 7364. - P. 312-316.

Yates A.M. The Earliest Post-Paleozoic Freshwater Bivalves Preserved in Coprolites from the Karoo Basin, South Africa / A.M. Yates, F.H. Neumann, P.J. Hancox // PLoS ONE. - 2012. V. 7, iss. 2. - e30228. doi:10.1371/journal.pone.0030228 


\title{
Increasing the efficiency of hard-to-recover oil production from a carbonate reservoir using thermochemical method
}

\author{
Sergey S. Sitnov, Albert F. Shageev, Emil R. Baigildin, Alexey V. Vakhin, Danis K. \\ Nurgaliev \\ Kazan Federal University, Kazan, Russia; sers11@mail.ru
}

Currently, as the conventional hydrocarbon reserves are depleting, there is a need for fundamentally new technologies that would help to include hard-to-recover reserves in development. In addition, it is estimated that more than $60 \%$ of the world's oil reserves are carbonate reservoirs, and most of them are complicated by the presence of high-viscosity oils. Companies face many difficulties during the development of such fields, including low permeability and porosity of the reservoir matrix, increased heterogeneity of the fractured and channeled systems, significant content of asphalt-resin-paraffin deposits in production wells, and high viscosity of the oil produced. In addition, in recent years, the interest of the world energy, environmental, and business community in the decarbonization, in particular, to utilization of associated gas has sharply intensified, both for environmental and financial reasons. In this regard, this work is devoted to developing a new combined technology of thermochemical treatment of a carbonate reservoir directly at the bottom of the well. This technology includes the generation in the downhole reactor of a significant amount of heat, active solvents, and organic carboxylic acids due to the oxidation of a wide light hydrocarbon fraction, a product of associated petroleum (dissolved) gas processing and gas condensate.

Under laboratory conditions, the experiment was carried out in a flow reactor. Inside the flow reactor, a cylindrical sample of carbonate rock was placed with a hexane fraction of hydrocarbons as a model system.

During the experiments, it was found that the composition of the oxidation product of light hydrocarbons is characterized by the presence of a mixture of saturated monobasic carboxylic acids, ketones, alcohols, and aldehydes during high-temperature generation. Wide range of solvents included in the oxidation products will dissolve deposits of asphalts, resins, and paraffins, if present in the bottom-hole formation zone, destroy the boundary layer of oil in contact with rockforming minerals, liquefy oil, increase its mobility. Due to the release of the pore space of rocks from high-molecular hydrocarbon compounds, the conditions for the access of carboxylic acids to the rock, chemical interaction with the carbonate reservoir will improve, which leads to an improvement in the hydrodynamic characteristics of the reservoir, namely an increase in the permeability and porosity of the reservoir and will allow for deeper treatments of the bottom-hole zone of the well.

As a result, these will provide an increase in permeability, decolmatation, heating of the bottom hole zone, and an additional decrease in the viscosity of the produced fluid as a result of heat and mass transfer between the heaters of the reactor and the injected liquid reagent and then between the oxidation products and the oil-saturated formation. 


\title{
The Makarovo Horizon (Famennian, western South Urals) in the regional scale of Devonian, correlation with the global standard
}

\author{
Rezeda Ch. Tagarieva \\ Institute of Geology Subdivision of the Ufa Federal Research Centre of the Russian Academy of Sciences, \\ Ufa, Russia; trezeda88@mail.ru
}

The Makarovo Horizon is the largest regional subdivision in the Famennian $\left(D_{3} f m\right)$ on the western slope of the South Urals. Since the 30s, XX century, it is known as the beds with Cheiloceras, Zilimia polonica and Cyrtospirifer archiaci (Markovsky, 1937; 1948). On conodonts it corresponds to the interval of the Upper triangularis, crepida, rhomboidea and Lower marginifera conodont zones (Kononova, 1969; Kononova, Lipina, 1971; Stratigraphic..., 1993; Baryshev, Abramova, 1996; Abramova, 1999; Resolutions..., 2008).

On conodonts in all sections there are established the stratigraphic gaps of various duration at the base and inside the Horizon. In the type Kuk-Karauk section the Middle-Uppermost crepida absence illustrates hiatus phenomenon (Abramova, 1999; Abramova, Artyushkova 2004; Artyushkova et. al., 2011; Tagarieva, 2013; Tagarieva, Mizens, 2015; Tagarieva et al., 2020; Tagarieva, 2020; Tagarieva, Artyushkova, 2020). In total well studied sections in the stratotype locality (Akkyr, Ryauzyak, Mendym et al.) (Abramova, 1999) may be considered as to add to the whole characteristic of Makarovo Horizon.

After detailed lithological and paleontological investigation of the Famennian Makarovo Horizon in the Kuk-Karauk stratotype section the stratigraphic volume was defined more exactly. It corresponds to the interval of the Upper triangularis, Lower crepida, rhomboidea, Lower and Upper marginifera Zones (Tagarieva; 2013; Tagarieva, 2020; Tagarieva, Artyushkova, 2020). According to the Stratigraphic schemes of the Urals (1993) the Upper marginifera Zone correlated to the Murzakaevo Horizon (beds with Zigania ursa) $\left(\mathrm{D}_{3} \mathrm{fm}_{2}\right)$ lower boundary. On the new faunal facts of the Makarovo/Murzakaevo Horizons boundary there is necessity to correct it. It is important to carry out special biostratigraphic, lithological, geochemical and event-srtatigraphic studies of deposits in stratotype and reference sections. New and complete characteristic of the straton will permit to confident regional, inter-regional and global correlations.

New data will make a valuable contribution to the solution of the problem of Lower and Middle Famennian boundary under discussion in SDS commission. Its stratigraphic position is proposed at the base of the Lower marginifera Zone (Streel et al., 1998; Geologic Time Scale, 2020). In respect to the South Ural's sections this level is recorded within Makarovo Horizon.

Sedimentological, paleontological and geochemical reflection of the Nehden (Middle Latest crepida Zones), Condroz (Late rhomboidea Zone) and Enkeberg (Lower marginifera Zone) Global Events may be retraced in the South Ural's sections within the Makarovo Horizon interval. 


\title{
Lithological and geochemical peculiarities of the Lower Triassic sandstones in the northern regions of the Timan-Pechora oil and gas- bearing Province
}

\author{
Natalia N. Timonina \\ Institute of Geology of FRC Komi SC UB RAS, Syktyvkar, Russia; nntimonina@geo.komisc.ru
}

Depositional settings and their effects on reservoir quality have particular interest for study of clastic reservoirs. The structural features, morphology and reservoir properties of natural reservoirs depended on both sedimentogenesis and the intensity of diagenetic transformations. The lithological and geochemical characteristics of sedimentary rocks gives useful information on the origin, tectonic settings, palaeoclimate and weathering patterns, transport system and diagenesis.

Triassic oil and gas bearing complex has a regional distribution. The central parts of the Korotaikha and Bolshesynya basins have the maximal thickness of the Triassic formation (2.8-3.6 $\mathrm{km}$ ). Hydrocarbon accumulation occurred in Triassic rocks largely in the northern part of the basin. Varandey, Toravey, Labagan fields of the Sorokin swell, Kumzhinskoe, Korovinskoe - in Denisov depression are main pools. The Lower Triassic includes Charkabozhskaya and Kharaleyskaya formations, the first one is represented by interbedding of red-colored clayey rocks with siltstones, sandstones and conglomerates, predominantly green and grayish-green in color.

The studies identified the origin of natural reservoirs as alluvial and allowed specifying the structure of sandy bodies, analyzed the mineral composition of sandstones and showed that the high variability of the composition and structure of cement minerals in reservoir rocks were associated with local facies - environments of sedimentation under the conditions of the river system.

The sedimentation conditions determined the granulometric composition and roundness of the fragments, the degree of their sorting, respectively, the configuration and sizes of the primary intergranular pores. Postsedimentary transformations resulted in a change in the primary void space.

The median content of $\mathrm{SiO}_{2}$ in sandstones is $60 \%$, the content of $\mathrm{Al}_{2} \mathrm{O}_{3}$ varies from 2.8 to 20.9 with a median of 13 . The minimum and maximum values of calcium oxide differ by an order of magnitude: 0.41 and $28 \%$, with an average value of $6 \%$.

To estimate the degree of chemical weathering of parent rocks and the maturity of the material entering the sedimentation area, we calculated the hydrolysate module, alumosilicate (AM), titanium, and sodium modules.

The CIA value varies from 18 to 92 with a median value of 69 . The limits of variation for $\mathrm{Na}_{2} \mathrm{O}$ and $\mathrm{K}_{2} \mathrm{O}$ are approximately comparable, with the median $\mathrm{K}_{2} \mathrm{O}$ (1.26) being less than $\mathrm{Na}_{2} \mathrm{O}$ (2.03). The $\mathrm{Al}_{2} \mathrm{O}_{3} / \mathrm{SiO}_{2}$ ratio varies from 0.14 to 0.34 with a median of 0.23 .

The minimum value of the hydrolysate modulus is 0.25 , the maximum is 0.62 . Based on this classification, the studied deposits belong to silites, hyposiallites, and normosiallites. 


\section{Lacustrine sediments variability on magnetic properties, mineral and chemical composition, lakes Bolshoye Miassovo and Turgoyak (South Urals)}

Anastasia R. Yusupova, Nuriia G. Nourgalieva, Dilyara M. Kuzina, Lina R. Kosareva, Pavel S. Krylov, Vadim V. Antonenko

Kazan Federal University, Kazan, Russia; yusupovaanast095@gmail.com

The work is devoted to the study of the magnetic and geochemical parameters of the Southern Urals lakes. The main aim of this investigation is to identify the events and trends of environmental and climate factors changes in the Late Quaternary.

The objects of research are the lakes of the Southern Urals: Turgoyak $\left(55^{\circ} 09^{\prime} 00^{\prime \prime} \mathrm{N}\right.$,

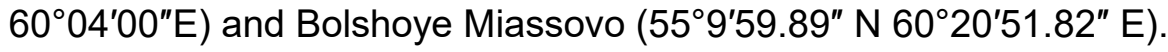

According of previously seismoacoustic studies, 5 core column were taken for each study lake. The total number of samples for Lake Turgoyak was 1275 samples (the length of column varies from 384 to $558 \mathrm{~cm}$ ), for Lake Bolshoye Miassovo - 1073 samples (the length of core columns changes from 282 to $526 \mathrm{~cm}$ ).

For a detailed complex analysis, core No. 3 of Lake Bolshoye Miassovo and No. 5 of Lake Turgoyak were selected according of the primary lithological description and the results of seismoacoustic studies.

According of radiocarbon dating results, the age of the Lake Turgoyak sediments is more than 25000 years; Lake Bolshoye Miassovo is 13500 years.

The detailed complex analysis included the measurements of magnetic susceptibility and natural remanent magnetization, coercive spectrometry, differential thermomagnetic analysis, scanning and transmission electron microscopy, and analysis of the chemical composition of sediments.

Normal-magnetization curves were used to determine the hysteresis parameters, the domain structure and ferrimagnetic grain sizes, as well as the contribution of para-, ferro- and superparamagnetic components to the total magnetic susceptibility. The results of elemental analysis were used to calculate the chemical alteration index CIA for assessing the intensity of chemical weathering and paleoclimate sedimentation conditions.

The integration of the values variations of magnetic-mineralogical and geochemical parameters made it possible to reveal the features of climatic and other environmental changes on the studied lacustrine sediments, by taking into account of regional data and in accordance with the periodization of the Blytt-Sernander scheme.

This study was funded by the Russian Foundation for Basic Research, project \#20-3590058. Part of the study conducted by D.M. Kuzina was funded with the subsidy allocated to the KFU in context of state assignment \# 671-2020-0049. 


\title{
Beds with conchostracans at the Upper Permian and Lower Triassic of Eastern Europe and Siberia
}

\author{
Veronika V. Zharinova \\ Kazan Federal University, Kazan, Russia; nika zharinova@mail.ru
}

Biostratigraphy of conchostracans is analyzed on the basis of their distribution in the sections of the East European Platform, Pechora platform, Kuznetsk Coal Basin, Siberian Platform and Southern Verkhoyanie. The author proposes the new biostratigraphic subdivisions in the rank of beds with conchostracans for the Severodvinian, Vyatkian and Induan deposits of Eastern Europe and Siberia.

Beds with Estheria elongata are identified for the Putyatinian Horizon of the Severodvinian Stage. Beds with Estheria elongata contain the conchostracan complex, including the species Estheria elongate Netschajew, 1894, E. lineata Lutkevich, 1941, E. cellelata Lutkevich, 1941, E. rotunda Lutkevich, 1941, E. angulata Lutkevich, 1941, Pseudestheria itiliana (Novojilov, 1950), Ps. novacastrensis (Mitchell, 1927), Ps. abramovi (Novojilov, 1970), Ps. exigua, Eulimnadia tobolica Novojilov, 1970, Palaeolimnadiopsis lundongaense Novojilov, 1970, Megasitum prodromus Novojilov, 1970. They are widespread in basins of the Klyazma, Volga, Kostroma, Lokhta, Sukhona, and North Dvina rivers.

Beds with Megasitum volgaense are identified for the Nefedovian and Zhukovian horizons of the Vyatkian Stage of the East European Platform and for the the Gagarieostrovian and Ivakinian horizons of the Upper Permian of the Siberian platform. Beds with Megasitum volgaense contain the conchostracan complex, including the species Megasitum volgaense Novojilov, 1970, M. jaroslavlense Novojilov, 1970, M. sotianum Novojilov, 1970, M. harmonicum Novojilov, 1970, Pseudestheria nordvikensis Novojilov, 1946, Ps. chatangensis (Novojilov, 1946), Ps. novacastrensis, Eulimnadia shorokhovi Novojilov, 1970. On the territory of the East European Platform, they are widespread in basins of the Vetluga, Velikaya, and Vyatka rivers. On the territory of the Siberian platform, they are widespread in basins of the Maymecha, Kotuy, and Lower Tunguska rivers.

Beds with Euestheria gutta are identified for the Induan and Olenekian stages of the East European Platform, Pechora platform, Kuznetsk Coal Basin, Siberian Platform and Southern Verkhoyanie. Beds with Euestheria gutta contain the conchostracan complex, including the species Euestheria gutta (Lutkevich, 1938), Limnadia blomi Novojilov, 1959, Lioestheria ignatjevi Novojilov, 1959, L. propinqua Novojilov, 1958, L. kubaczeki Voltz, 1937, Pseudestheria kashirtzevi Novojilov, 1959, Ps. putjatensis Novojilov, 1959, Ps. rybinskensis Novojilov, 1959, Ps. wetlugensis Novojilov, 1959, Ps. pliciferina Novojilov, 1959, Ps. vjatkensis Novojilov, 1959, Wetlugites pronus Novojilov, 1958, Concherisma tomensis Novojilov, 1958, Sphaerestheria aldanensis Novojilov, 1959, Sph. belorussica Novojilov, 1954, Cyclestheria rossica Novojilov, 1959, Echinolimnadia mattoxi Novojilov, 1965, Palaeolimnadiopsis albertii (Voltz, 1837), P. brevis Novojilov, 1958, P. vilujensis Varentsov, 1955, Lioleaiina triasiana (Chernyshev, 1934), Vertexia tauricornis Lutkevich, 1941, Cornia melliculum Lutkevich, 1941, C. germari (Beyrich, 1857), Loxomicroglypta nodosa Novojilov, 1946, Magniestheria mangaliensis (Jones, 1862).

The work is supported by the subsidy allocated to Kazan Federal University for the state assignment \# 671-2020-0049 in the sphere of scientific activities. 


\title{
Mid-Famennian negative C-isotope excursion in the Izyayu River section (Tchernyshev Uplift, Pechora Plate)
}

\author{
Andrey V. Zhuravlev ${ }^{1}$, Denis A. Gruzdev ${ }^{1}$, Yadviga A. Vevel ${ }^{1}$, Andrey V. Erofeevsky ${ }^{1}$ \\ ${ }^{1}$ N.P. Yushkin Institute of Geology Komi SC UrB RAS, Syktyvkar, Russia; micropalaeontology@gmail.com
}

The Famennian was a time of significant perturbations in the carbon cycle caused by the onset of the Late Palaeozoic Glacial Age. The prominent negative excursion in the isotopic composition of inorganic carbon is known in the Lower-Middle Famennian (Palmatolepis rhomboidea-Palmatolepis marginifera marginifera conodont zones) of North America and Southern and Central Europe. This excursion is discovered in the calciturbidite sequence in the southern part of the Tchernyshev Ridge (East of Timan-Pechora basin).

$\delta^{13} \mathrm{C}_{\text {carb }}$ values decrease from around $+1 \%$ in the Pal. rhomboidea conodont Zone to minimum values around $-1 \%$ in the upper part of Pal. rhomboidea-Pal. gr. gracilis Zone interval, and are followed by a gradual increase to values around $+1.5 \%$ during the Pal.marg.marginifera Zone. The negative C-isotope excursion spans Pal. rhomboidea-Pal. marg. marginifera conodont zones interval. The amplitude of the excursion is about $-2.5 \%$.

Variations in isotope composition of carbon of conodont elements $\left(\delta^{13} \mathrm{C}_{\text {con }}\right)$ of Palmatolepis glabra group were evaluated in the stratigraphic interval under consideration. $\delta^{13} \mathrm{C}_{\text {con }}$ values decrease from $-25.7 \%$ to $-28.3 \%$ in the Pal.rhomboidea-Pal. gr. gracilis Zone interval. Gradual increasing of $\delta^{13} \mathrm{C}_{\text {con }}$ values starts at the middle part of the Pal.marg.marginifera Zone. The $\delta^{13} \mathrm{C}_{\text {con }}$ values reach $-25.6 \%$ in the Pal.marg.utahensis Zone. Generally, $\delta^{13} \mathrm{C}_{\text {con }}$ variations are conforming to those of $\delta^{13} \mathrm{C}_{\text {carb. }}$. The amplitude of the negative excursion in $\delta^{13} \mathrm{C}_{\text {con }}$ is about $-3 \%$.

Similar variations in the isotopic composition of carbon of carbonates (amplitude of about $2.5 \%$ ) and of conodont elements (amplitude of about $-3 \%$ ) suggest significant changes in carbon isotopic composition in early-middle Famennian pelagic ecosystems. It is supposed that carbon emission from hydrotherms or/and volcanos accompanied with glacioeustatic regression were the most probable causes of Mid-Famennian negative carbon isotope excursion. 


\title{
Unfavorable habitat for benthic foraminifers during the Late Jurassic OAE and Early Aptian OAE 1a in the epeiric sea of the eastern part of the Russian Platform
}

\author{
Svetlana O. Zorina \\ Kazan Federal University, Kazan, Russia; svzorina@yandex.ru
}

The most disastrous consequence of the Early Aptian Oceanic Anoxic Event (OAE) in the epeiric sea of the eastern part of the Russian Platform for benthic foraminifers (BF) was oxygen decrease and the onset of sulphidic conditions associated with toxic enrichment in heavy metals. The latter can be regarded as one of the main causes for BF distress and even their disappearance.

Twenty-eight cores of bituminous rocks from two anoxic levels (Late Jurassic OAE and Early Aptian OAE 1a) and host mudrocks were sampled from the Upper Jurassic-Lower Cretaceous section of the Tatar-Shatrashany borehole (eastern part of Russian Platform). Trace element analyses were undertaken using ICP-MS for estimating the extent of sediment contamination in ten toxic metals ( $\mathrm{As}, \mathrm{Cd}$, Se, $\mathrm{Pb}, \mathrm{Zn}, \mathrm{Ni}, \mathrm{Mo}, \mathrm{Cu}, \mathrm{V}$, and $\mathrm{W}$ ). Geoaccumulation index $\left(I_{\text {geo }}\right)$ was calculated by comparing the current concentration of each metal with geochemical background value metal in Upper Continental Crust. At the same time, the total number of BF (number of specimens per $1 \mathrm{~m}^{2}$ ) and the number of species in the sample were counted for the vast complexes of BF found in the studied section.

The integrated data handled evidence for mostly dysoxic conditions in the epeiric sea of the eastern part of the Russian Platform during the Late Jurassic OAE. The habitat conditions were not totally destructive for BF. The most toxic-resistant species is Lenticulina infravolgaensis (Furs.et Pol.).

Strong anoxia in Early Aptian OAE 1a contributed to extremely contaminated sediments is considered fatal for BF. The only toxic-resistant species that successfully recovered from the toxic stress is the zonal species Mjatliukaena aptiensis (Mjatl.).

The Lower Aptian black shales show extreme contamination by Mo and Cd. Thus, the anoxic environment can be regarded as becoming not suitable for BF inhabitance also totally without oxygen and with an excess of free hydrogen sulfide in anoxic conditions. 


\section{Миоспорты и криптоспоры из визейских отложений Волго- Уральской области}

\section{Акишина O.В.}

Казанский (Приволжский) федеральный университет, Казань, Россия; OlgVAkishina@stud.kpfu.ru

Изучены миоспоры из глинистых пород визейского яруса, отобранных из скв. 4482 Ново-Елховской площади Ромашкинского месторождения.

В результате палинологического анализа установлены многочисленные споры следующих видов: Lycospora pussilla (lbr) Som.-Somer, Cingulizonates bialatus Butterworth et al., Waltzispora lobophora (Waltz) Stapl., и Vallatisporites punctatus (Naum.) Oshurk. Единичные споры представлены видами Knoxisporites multiplicabilis (Kedo) Oshurk.; K. literatus (Waltz) Playford, Murospora aurita (Waltz) Playford, Reticulatisporites magnus (Kedo) Byvsch., Simozonotriletes serratus (St.) Byvsch., Diatomozonotriletes saetosus (Hacquebard et Barss) Hughes et Playford, Tripartites incisotrilobus (Waltz) Potonie et Kremp, Vallatisporites variabillis (Waltz) Oshurk., Triqutriletes sp. и др.

Установленные виды миоспор, в основном, принадлежат родам из семейства плауновидных (Lepidodendraceae), хвощевидных (Equisetace) и папоротникообразных (Polypodiophyta).

Комплекс миоспор подтверждает визейский возраст вмещающих пород и свидетельствует об обильной и разнообразной растительности, произраставшей во влажном тропическом климате.

Совместно с миоспорами встречены единичные переотложенные диады криптоспор (Cryptospores), не характерные для каменноугольных отложений Волго-Уральской области. Считается, что криптоспоры - это споры первых наземных растений, обладающие устойчивой оболочкой и постоянным наличием диад и тетрад. Криптоспоры появились в раннем ордовике, достигли расцвета в силуре и полностью исчезли в раннем девоне. Их находки известны на всех континентах.

Присутствие ордовикско-силурийских криптоспор в отложениях визейского яруса Волго-Уральской области можно объяснить поступлением обломочного материала из областей сноса, расположенных по периферии раннекаменноугольного бассейна (Прибалтика, Поморье и т.д.). Это согласуется с современными палеогеографическими построениями. 


\title{
О возрастном положении разреза Куеда-Ключики - уникального местонахождения позвоночных средней перми (Пермский край)
}

\author{
Бакаев А.С. ${ }^{1}$, Буланов В.В. ${ }^{1}$, Илалтдинов И.Я. ${ }^{2}$, Кожанов Д.Д. ${ }^{3}$, Пономарева Г.Ю. ${ }^{2}$, \\ Хопта И.С. ${ }^{2}$ \\ 1Палеонтологический институт им. А.А. Борисяка, Москва, Россия; alexandr.bakaev.1992@mail.ru \\ Пермский государственный национальный исследовательский университет, Пермь, Россия \\ ${ }^{3}$ Московский Государственный Университет им. М.В, Ломоносова, Москва, Россия
}

Местонахождение пермских позвоночных Куеда-Ключики находится на юге Пермского края в Куединском районе, открыто в 2005 г. Этот исключительно важный разрез имеет разные возрастные датировки по геологическим и палеонтологическим данным.

В тектоническом плане разрез находится в северной части Башкирского свода на востоке Русской плиты. По данным геологосъемочных работ масштаба 1: 200000 на территории Куеда-Ключики выделены бураевская и чекмагушевская толщи шешминской свиты уфимского яруса. Нижнебелебеевская подсвита казанского яруса выделена в 6 км к северо-западу от карьера. В разрезе имеются два фаунистических уровня, связанных с серыми и желтовато-серыми тонкоплитчатыми мергелями, глинистыми известняками.

Местонахождение содержит остатки водных позвоночных - рыб, амфибий и рептилий. Описаны новые виды насекомых. Ископаемая фрлора включает хвощевидные, пельтаспермовые птеридоспермы, гинкгофиты, войновскиевые и хвойные. Фаунистический комплекс весьма своеобразен. Присутствие в ориктоценозе актиноптеригий Kazanichthys viatkensis и Kargalichthys efremovi, а также котлассиидных сеймуриаморф рода Leptoropha «отправляет» разрез в верхнеказанский подъярус. Однако в пользу уфимского возраста свидетельствуют следующие факты. В ориктокомплексе массовой фрормой являются дискозаврисцидные сеймуриаморфы, известные только из нижней перми Центральной Европы и Средней Азии. Состав комплекса лучеперых рыб несколько отличается от типичных верхнеказанских местонахождений Аксаково и Шихово-Чирки (Кировская обл.). Новый вид мисхоптеридовых насекомых Aspidothorax permianus относится к роду, представители которого распространены в верхнем карбоне Франции и Германии.

Для уточнения возраста проведен сравнительный минералогический анализ тяжелой фрракции терригенных пород пермского возраста. Для этого на территории Пермского края отобраны шестнадцать точечных литологических проб из песчаников и конгломератов шешминской и белебеевской свит. Полученные результаты коррелируются с проведенными ранее исследованиями на территории Пермского края, Татарстана, Башкортостана, Удмуртии, Кировской области. Терригенные породы разреза Куеда-Ключики по количеству минералов группы эпидота и черных рудных минералов в тяжелой фракции близки значениям шешминской свиты. Как и в породах белебеевской свиты здесь отсутствуют пироксены, амфиболы, отмечается снижение содержания терригенных устойчивых минералов.

В разрезе Куеда-Ключики из мергелей и глинистых известняков методом горячей экстракции получены битумоиды. Для сравнения геохимические исследования проведены с известняками белебеевской свиты разреза Посад. По характеру распределения членов гомологического ряда н-алканов ОВ образцов характеризуется как сапропелевое, малопреобразованное, аллохтонно-автохтонное вмещающим отложениям (с различной степенью сингенетичности). Однако имеются различия. Значения отношения четных членов гомологического ряда н-алканов к нечетным, а также характеристика СРІ, дают 
противоречивую оценку типа ОВ, а также его катагенетической преобразованности. Битумоид обнажения Куеда-Ключики демонстрирует просто немыслимые для сапропелевого типа ОВ значения НЧ/Ч $(2,31)$ и СРI $(2,56)$. В куединских битумоидах зафиксировано высокое содержание углеводорода тритерпанового ряда, являющегося биомаркером. Мы можем говорить о том, что исходное органическое вещество образца из обнажения Куеда-Ключики было образовано за счет бактериальной слизи, накопленной в лагунных обстановках с повышенной соленостью вод. Битумоид обнажения Посад образован за счет сапропелевого $\mathrm{OB}$, накопленного в прибрежно-морских восстановительных условиях. 


\title{
Иноцерамоподобные двустворчатые моллюски и великое позднепермское вымирание на Северо-Востоке Азии
}

\author{
Бяков А.C. \\ Северо-Восточный комплексный научно-исследовательский институт им. Н.А. Шило ДВО РАН, \\ Магадан, Россия; abiakov@mail.ru \\ Казанский фредеральный университет, Казань, Россия \\ Северо-Восточный государственный университет, Магадан, Россия
}

Иноцерамоподобные двустворчатые моллюски являются характернейшим элементом пермской высокобореальной фауны. Появившись в середине ранней перми, они играли доминирующую роль в сообществах бентоса вплоть до конца пермского периода. Уже в поздней перми иноцерамоподобные двустворки значительно преобладали над брахиоподами, особенно в бассейнах с терригенной седиментацией.

Позднегваделупское вымирание значительно затронуло все группы фауны, в том числе и иноцерамоподобных двустворок (Бяков, 2012). Однако, уже во второй половине вучапина они испытали новый расцвет, связанный с появлением и бурным развитием рода Intomodesma, представители которого вместе с другим родом - Maitaia заселили как мелководные, так и глубоководные биотопы на огромных пространствах от Таймыра до северо-восточно-азиатской окраины и даже, возможно, достигли Северной Америки. В это время разнообразие иноцерамоподобных двустворок достигает 14 видов и появляются самые крупные их представители, длина которых составляла более полуметра. Число отдельных особей было также очень велико, о чем свидетельствуют целые «кладбища» интомодесм и майтай как в разрезах Верхояно-Охотского, так и Колымо-Омолонского регионов. Такому процветанию иноцерамоподобных форм, очевидно, способствовали и благоприятные температурные условия существования фрауны - до $+23.1^{\circ} \mathrm{C}$ (Zakharov et al., 2005).

Во второй половине чансина мелководные биотопы, наиболее благоприятные для обитания разнообразной фауны, вследствие глобальной регрессиии, вызванной ростом Сибирского суперплюма, начали исчезать. Кроме того, негативно сказалось на организмы и поступление ряда токсичных веществ, в первую очередь, сероводорода. Максимального влияния эманации Сибирского суперплюма на морскую биоту бассейнов Северо-Востока Азии достигли во второй половине позднего чансина, когда практически вся бентосная биота погибла. Этот момент фиксируется в ряде глубоководных бассейнов Северо-Востока Азии (Аян-Юряхском, Балыгычанском, северо-восточной периферии Охотского) полным исчезновением остатков какой-либо фрауны и следов биотурбации, появлением тончайшей ламинарной слоистости, резким уменьшением содержания биогенного кремнезема и повсеместным проявлением признаков аноксии (Бяков, Ведерников, 2007).

Однако, какие-то рефугиумы жизни, очевидно, могли сохраняться кое-где среди этого «океана смерти» в относительно мелководных обстановках Верхоянского и Балыгычанского бассейнов, о чем свидетельствуют пережившие это вымирание единичные потомки пермской морской биоты (в том числе и иноцерамоподобные двустворки-майтайи), а также палеотаксодонты и гастроподы-беллерофонтиды. В нижнем триасе Северо-Востока Азии иноцерамоподобные представлены двумя видами: Maitaia errabunda (Popow) и Maitaia sp. B изобилии они встречены в отложениях верхнего инда и нижнего оленека, после чего все майтайи внезапно полностью вымирают.

Исследования выполнены при поддержке РФФИ, проект № 20-05-00604. 


\title{
Изотопные исследования углерода пермских известняков юго- восточной части Омолонского массива
}

\author{
Брынько И.В ${ }^{1}$., Бяков А.С. ${ }^{1,2}$, Ведерников И.Л. ${ }^{1}$ \\ ${ }^{1}$ Северо-Восточный комплексный научно-исследовательский институт им. Н.А. Шило ДВО РАН, \\ Магадан, Россия; ibrynko@mail.ru \\ ${ }^{2}$ Северо-Восточный государственный университет, Магадан, Россия
}

Изотопные исследования углерода используются для корреляции разрезов, а также для палеогеографических реконструкций прошлого. В настоящем исследовании

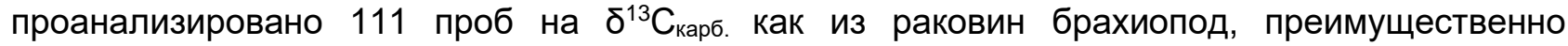
спирифирид (63 пробы), так и из вмещающих пород - колымиевых известняков (48 проб) из трех пермских разрезов по р. Русская-Омолонская, р. Мунугуджак, руч. Федоровский.

Для корректной интерпретации $\delta^{13} \mathrm{C}_{\text {карб. }}$ с целью исключения диагенетических изменений были использованы: визуальная оценка перекристаллизации раковин брахиопод, определение методом ICP-MS содержания $\mathrm{Mn}$, $\mathrm{Sr}$ и $\mathrm{Fe}$ в известняках. Согласно этим критериям, колымиевые известняки оказались пригодны для дальнейшего изучения. Для раковин брахиопод основным критерием для разграничения диагенетических изменений являлась величина $\delta^{13} \mathrm{C}_{\text {карб. }} \geq-8 \%$, поэтому из дальнейшей обработки данных исключены 4

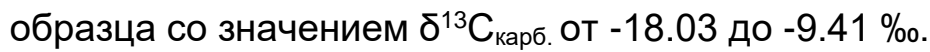

Для нижнепермских отложений (ассельско-нижнеартинский интервал) материалом

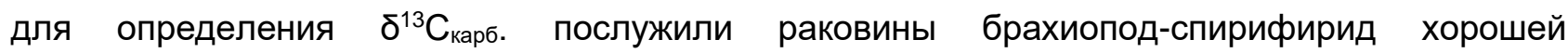
сохранности; полученные нами значения колеблются от -5.22 до $+3.16 \%$. По этим данным можно предположить два варианта интерпретации полученных низких значений $\left.\delta^{13} \mathrm{C}_{\text {карб.: }} 1\right)$ раковины были подвержены диагенезу; 2) влияние особенностей местных условий осадконакопления.

Для нижне-среднепермских отложений (верхнеартинско-вордский интервал)

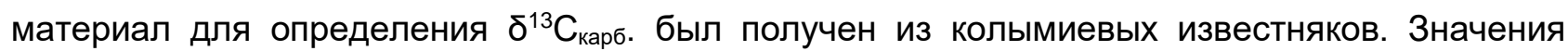

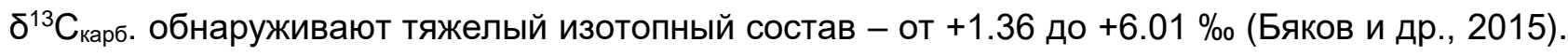
Такие содержания, скорее всего, свидетельствуют о повышенной биопродуктивности бассейна, что можно объяснить деятельностью бактериальных организмов (Ганелин, 2013).

Для верхнепермских отложений (кепитенско-вучапинский интервал) материал на

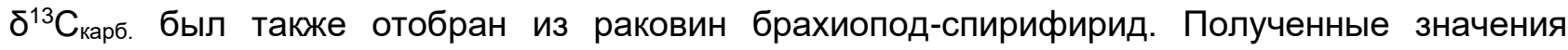
показывают резкое облегчение $\delta^{13} \mathrm{C}_{\text {карб }}$ - до -8\%, что может быть связано с активизацией вулканической деятельности Охотско-Тайгоносской вулканической дуги (Бяков, 2012). Но, также нельзя исключить их и определенные диагенетические изменения.

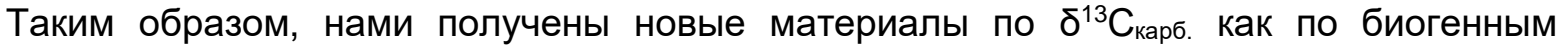
карбонатам, так и по вмещающим известнякам, эти данные позволили дополнить тренд по

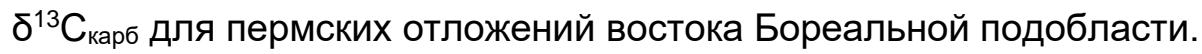

Исследования выполнялись при поддержке РФФИ № 20-05-00604. 


\section{Поиск перспективных на углеводороды объектов на основе геолого-геофизических данных В отложениях Саргаевского горизонта на северо-востоке Республики Татарстан}

Воронков С.E.

Казанский (Приволжский) Федеральный Университет, Казань, Россия; seregaw.19@mail.ru

В настоящее время весьма актуальна проблема истощения запасов горючего сырья, как в целом мире, так и в отдельно взятых регионах. Большинство месторождений Республики Татарстан находится на поздней стадии разработки, то есть характеризуется высокой степенью выработанности (в частности, по терригенному девону) и существованием проблемы недостатка возвратных объектов по основной части фонда скважин.

Целью данной работы является выявление перспективных на углеводороды объектов в саргаевском горизонте на основе данных ГИС и геолого-промысловых данных по скважинам, в которых были получены притоки нефти.

Основным объектом исследований является нефтяное месторождение, расположенное в северо-восточной части Республики Татарстан, в тектоническом плане приуроченное к юго-восточному склону Северо-Татарского свода. На месторождении продуктивными являются терригенные отложения пашийского и тиманского горизонтов верхнего девона. Месторождение эксплуатируется с 1955 года. Сегодня оно находится на IV стадии разработки и относится к категории истощённых месторождений.

В работе основным объектом исследований является саргаевский горизонт, отличившийся притоками нефти в ряде скважин. Проведены анализ и интерпретация данных ГИС (радиоактивный и электрический каротаж) по скважинам изучаемого месторождения (фонд включает более 400 скважин). В подошве саргаевского горизонта установлен наиболее продуктивный интервал Dsr1. Для этого интервала построены карты информативных геофизических параметров с выделением перспективных на углеводороды зон на площади месторождения, рекомендуемых для дальнейших перфорационных работ и составления перечня возвратных объектов, за счёт которых возможен прирост запасов углеводородов. 
Перспективы

нефртегазоносности

юго-западной

части

Краснодарского края по результатам гидрохимических исследований пластовых вод Западно-Кубанского и КерченскоТаманского прогибов

Зуб О.Н.

Кубанский государственный университет, Краснодар, Россия; geokub@bk.ru

В данной работе по результатам гидрохимических исследований пластовых вод предпринята попытка с новых позиций рассмотреть перспективы нестегазоносности югозападной части Краснодарского края, в зонах сочленения Западно-Кубанского и КерченскоТаманского прогибов.

В результате исследования гидрохимических обстановок выявлен ряд специфических черт гидрохимической обстановки исследуемой площади:

1. Происходит изменение минерализации пластовых вод. Она возрастает от понта к сармату и уменьшается от сармата до чокрака.

2. Меняются типы вод в разрезе понта: хлоридо-магниевые, а в чокраке гидрокарбонатно-натриевые. Изменение типов вод, можно истолковать интеграцией эпигенетических вод, которые отжаты из глин. Были выявлены характеристики гидрохимических условий Джигинской зоны в сравнении с Благовещенской. Вне зависимости от установленной минерализации пластовых вод, воды Джигинки можно отнести к гидрокарбонатно-натриевым.

3. Миоценовым водам изучаемых зон присуще наличие высоких концентраций йода (до 70 мг/дм³ ) и брома (до 148 мг/дм³). Значительные показатели микроэлементов в водах раскрывают их талассогенную сущность. Коррелятивная связь между количеством микроэлементов и нефтегазоносности толщи миоцена в Благовещенской и Джигинской зонах не прослеживается.

4. Схожесть гидрохимических условий миоценовых залежей исследуемых зон подтверждает единство палеогеографической обстановки и геологических условий, воздействующих на их развитие. 


\section{Органическое вещество, его генерационный потенциал и состав артинских отложений севера Предуральского краевого прогиба (Тимано-Печорская провинция)}

Котик О.С., Салдин В.А.

Институт геологии им. академика Н. П. Юшкина Коми НЦ УрО РАН, Сыктывкар, Россия; olga.procko@gmail.com; litgeo@geo.komisc.ru

Территория севера Предуральского краевого прогиба и прилегающие области западного склона Урала являются перспективными для поисково-разведочных работ на нефть и газ в Тимано-Печорской провинции. Артинские терригенные отложения, входящие в состав пермского нефтегазоносного комплекса широко распространены на исследуемой территории.

Породы очень разнообразны по составу (кластолиты, пелитолиты, карбонатолиты и микстолиты) и структурно-текстурным особенностям. На востоке изучаемой территории севера Предуральского краевого прогиба в артинский век происходит образование глубоководной депрессии, заполняемой терригенными флишевыми отложениями. По простиранию в западном направлении, в пределах Кочмесской площади, в артинский век продолжалось карбонатное осадконакопление в мелководно-шельфовых условиях. В позднеартинско-раннекунгурское время повсеместно накапливались терригенные и терригенно-карбонатные отложения нижней молассы в мелководно-морских условиях. Артинские молассовые отложения представлены тонким чередованием смешанных кремнисто-терригенных и карбонатных пород.

Современные содержания $\mathrm{C}_{\text {орг }}$ в глинистых породах фрлишевых отложений изменяются от $0.7 \%$ (р. Силоваяха) до $3.7 \%$ (р. Кожим), а в аргиллитах терригенной и терригенно-карбонатной молассы - 0.5-3.8 \%. В составе ОВ преобладает битуминит (сапропелевая основа), а гумусовая составляющая доминирует в восточных районах, примыкающих к Уралу. Установлено наличие бедных и средних нефтегазоматеринских пород, водородный индекс (HI) меняется от первых десятков до 240 мг УВ/г Сорг. Снижение генерационного показателя происходит за счет большой доли гумусового детрита в составе ОВ. Наиболее высокие значения НI - 240 мг УВ/г С орг определены в микстолитах Кочмесской площади, где в составе ОВ преобладает битуминит.

Катагенетическая преобразованность ОВ артинских пород изменяется от градаций катагенеза МК 1 -МК 2 на западном борту Косью-Роговской впадины до градации АК 1-2 на ее восточном борту и в Коротаихинской впадине. Данные углепетрографии и пиролиза подтверждают незаконченную генерацию УВ в артинских отложениях Кочмесской, ХоседаюНеруюсской, Бергантымылькской, Падимейской и Южно-Степковожской площадей, где данные отложения еще не вышли из зоны нефтяного окна (градация катагенеза, МК 2 ). 


\section{Поздний палеозой Бамбуйско-Олингдинской синформы Западного Забайкалья}

Минина О.P.

Геологический институт СО РАН, Улан-Удэ, Россия; yaksha@rambler.ru

Бамбуйско-Олингдинская подзона входит в состав Витимкан-Ципинской зоны и занимает южные отроги Южно-Муйского хребта. В структурном плане подзона образует крупную синформу, в которой выделяются поля докембрийских метаморфических пород и слабо метаморфизованных отложений нижнего и верхнего палеозоя, выделенные из состава рифейских и нижнепалеозойских комплексов. Фундамент, на котором формировались отложения первой половины верхнего палеозоя, образуют комплексы байкальского и каледонского структурных этажей, разделенных поверхностями региональных несогласий.

Комплексы раннегерцинского структурного этажа объединяют палеонтологически охарактеризованные отложения двух стратиграфических уровней. Нижний уровень включает бамбуйскую $\left(D_{1-2 Z v}\right)$ и чулегминскую $\left(D_{3} f_{3}\right)$ свиты и кадалинскую толщу $\left(D_{3} f k d\right)$. Верхний уровень включает уендектскую $\left(\mathrm{D}_{3} \mathrm{fm}-\mathrm{C}_{1} \mathrm{t}\right)$ толщу, огненскую $\left(\mathrm{C}_{1} \mathrm{t}\right)$ и аматканскую $\left(\mathrm{C}_{1} \mathrm{v}\right)$ свиты. Бамбуйская свита имеет известняково-доломитовый состав, кадалинская толща сложена глинистыми известняками, доломитами с прослоями алевролитов и аргиллитов. Эти породы отвечают 2, 3, 4, 7 и 8 стандартным фрациальным поясам карбонатонакопления Дж. Уилсона. Терригенная чулегминская свита представлена отложениями аллювиальных конусов, которые сменялись комплексами субаквальной дельты. Огненская свита характеризуется преобладанием темноокрашенных глинистых и тонкообломочных пород, формировавшихся в глубоководном троге. Аматканская свита представлена терригенным комплексом крупной аллювиально-дельтовой равнины. Тефротурбидиты и лавовые горизонты уендектской толщи отвечает фациям открытого морского бассейна, примыкавшего к зоне вулканизма.

Осадочный комплекс среднего-верхнего девона представляет собой отложения шельфового палеобассейна, седиментация которых происходила в спокойных тектонических условиях. Обстановка изменилась в конце позднего девона-раннем карбоне, осадконакопление происходило в открытом шельфово-склоновом палеобассейне, на начальных этапах эволюции мелководном, затем углубляющемся и примыкающим к зоне вулканизма. 


\section{Влияние вторичных процессов на коллекторские свойства карбонатных пород казанского яруса на примере Мелекесской впадины}

Мударисова Р.А. ${ }^{1}$, Фахрутдинов И.Р. ${ }^{2}$, Фахрутдинов Э.И. ${ }^{1}$

${ }^{1}$ Казанский федеральный университет, Казань, Россия; rayshania@mail.ru

${ }^{2}$ Институт проблем экологии и недропользования АН РТ, Казань, Россия

Известно, что с рифовыми телами, выступающими в качестве ловушек, связано большое количество залежей УВ как в России, так и за рубежом, так как отличительной особенностью рифов является их высокая первичная пористость в отличие от обычных карбонатов. Одним из таких и является Горское месторождение сверхвязкой нефти (СВН) приурочено к крупной структуре, расположенной в краевой части восточного борта Мелекесской впадины. На Горском месторождении узкий диапазон промышленных скоплений, основные продуктивные отложения приурочены к камышлинскому горизонту казанского яруса.

По микроописанию керна горные породы нижнеказанского яруса в соответствии со структурной классификации Р. Данхэма представлены пятью основными литотипами карбонатных пород: интракластовый долопакстоун (реликтово-органогенный доломит), пористый оолитовый долопакстоун/дологрейстоун (оолитовый доломит), пелоидный долостоун, глинистый долостоун, брекчиевидный долостоун. Первые два литотипа имеют широкое распространение на Горской структуре и являются основными коллекторами СВН. По данным лабораторных исследований для литотипа 1: коэффициент открытой пористости: $\mathrm{m}=2.83-28.41 \%$, со средним значением 13.9\%, коэффрициент проницаемости кпр $=1.01-1564.2$ мкм ${ }^{2}$, среднее - 130.27 мкм², коэфрфициент битумонасыщенности кб/н $=2.24-87.63 \%$ к объему пор, среднее - 41.32\%, коэфффициент, учитывающий объем пор за исключением объема остаточной воды, от 40.84 до 93,36\%, среднее - 67.14 \%. Для литотипа 2: m=1.96-37.9\%,

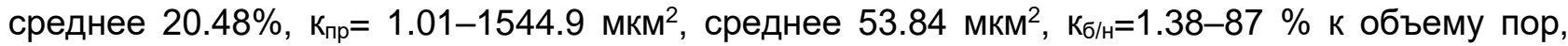
среднее $53.84 \%$, коэффициент, учитывающий объем пор за исключением объема остаточной воды, от 44.95 до $88.63 \%$, среднее - $69.28 \%$.

Выявлены основные постседиментационные преобразования карбонатных пород, оказывающие наибольшее влияние на коллекторские свойства: выщелачивание, доломитизация, сульфатизация, вторичная кальцитизация, окремнение. Из данных фракторов только выщелачивание положительно влияет на коллекторские свойства долостоунов. Изучение особенностей литологического состава коллекторов по данным керна позволяет выбрать подходящие технологии воздействия на пласты. 


\section{Граница серпуховского и башкирского ярусов в разрезах Губахи (Средний Урал, Пермский край)}

Пономарева Г.Ю.

Пермский государственный национальный исследовательский университет, Пермь, Россия; galina@tiron.ru

Пограничные отложения серпуховского и башкирского ярусов в окрестности г. Губахи обнажаются в трех разрезах: Верхняя Губаха (сл. 13-14), гора Ладейная (сл. 29-30) и Мариинский Лог (сл. 1, обн. 4R). Осложняющим фрактором является отсутствие сплошных выходов в этом интервале. Однако в совокупности три разреза закрывают староуткинский горизонт серпуховского яруса и основание башкирского. На территории ВишерскоЧусовского Урала староуткинский горизонт характеризуется как слои с Plectostaffella и Endothyranopsis. Нижняя граница староуткинского горизонта установлена в разрезе Верхняя Губаха в слое 13 по появлению Plectostaffella ex gr. varvariensis Brazhn. et Pot. Ниже основания башкирского яруса находятся известняки темно-серые, мшанковоархедисцидовые, с желваками розового кремня, слоистые (9-12 см) мощностью 2,5 м. Микрофация - мелкобиокластовый пакстоун, вакстоун. Среди разнообразных архедисцид выделяются Archaediscus gigas Raus., Eosigmoilina explicata Gan., Eosigmoilina explicata evoluta Brazhn., Brenckleina rugosa (Brazhn.), а также Endothyranopsis plana Brazhn., Eostaffella mutabilis Raus., Eostaffella acuta nana Kir., Ikensiformis mirifica (Brazhn.), Plectostaffella seslavica Rum., Plectostaffella longa Rum., Millerella angusta (Kir.). Эта толща резко отличается от светло-серых доломитизированных биокластовых грейнстоунов, пакстоунов протвинского горизонта к тому же лишенных конодонтовой фауны. B слоях 1 (4R, Мариинский Лог) и 30 (гора Ладейная) А.С. Алексеевым определены конодонты Gnathodus bilineatus (Roundy), G. cf. bollandensis Hig. et Bouck., G. postbilineatus Nigm. et Nem., Lochriea mononodosa (Rh., Aust. et Dr.), L. ziegleri Nem., Per. et Meisch. Мелкобиокластовый пакстоунвакстоун соответствует последнему трансгрессивному импульсу серпуховского яруса, связанным с ледниково-эвстатическими колебаниями. Полученная микрофраунистическая характеристика делает возможной корреляцию разрезов Губахи с GSSP башкирского яруса каньоном Эрроу (Невада, США).

Граница башкирского яруса обнажена в разрезе Мариинский Лог (сл. 2, 4R). Здесь трансгрессивный биокластик сменяется регрессивными брекчиевидными и строматолитовыми известняками, биокластовыми грейнстоунами. Есть основание полагать, что амплитуда перерыва несколько меньше, чем считалось ранее. Комплекс фрораминифер сл. 2 включает виды зоны Semistaffella variabilis: Semiendothyra surenica Reitl., Globivalvulina bulloides (Brady), Semistaffella cf. primitiva Reitl., Semistaffella variabilis (Reitl.). В кровле слоя 2 (1.7 м от подошвы и границы) появляется Pseudostaffella antiqua (Dutk.). Конодонты не обнаружены. 


\title{
Миоспоры из нижнефранских отложений чаплыгинской свиты Воронежской антеклизы
}

\author{
Раскатова М.Г. ${ }^{1}$ Юрина А.Л. ${ }^{2}$ \\ 1Воронежский государственный университет, Воронеж, Россия; mgraskatova@yandex.ru \\ ${ }^{2}$ Московский государственный университет им. М.В. Ломоносова, Москва, Россия
}

Проведено изучение чаплыгинской свиты на основании нового палинологического материала (скважины Новохоперская 8750/1-Воронежская обл., Щигры-19-Курская обл.) и на переизучении прежнего (более 10 номерных скважин Воронежской, Липецкой и Белгородской обл.) Выделены последовательно сменяющие друг друга в разрезе палинокомплексы: ПК2, ПКЗ и ПК4 в чаплыгинской свите. Комплекс ПК2 (нижняя часть существенно глинистой пачки основания чаплыгинской свиты) содержит виды, характерные для лоны Raistrickia bucera-RBu, впервые установленной в нижнефранском желонском горизонте Беларуси, скоррелированным с нижнетиманским подгоризонтом ЦДП. Мы полагаем, что R. bucera следует считать не лоной, а общей палинозоной, учитывая более широкое еe географическое распространение (Беларусь, Россия). Палинологическим маркером этой зоны является R. bucera, однако его появление в разрезах ЦДП не всегда фриксируется начиная с ее основания. В одних разрезах появление его составляет 1-3\%, в других разрезах он не отмечается. Содержание вида-индекса Tholisporites variabilis insignis имеет аналогичную картину. Подобная ситуация с этими видами наблюдается в разрезах Беларуси в зоне R. bucera (Obukhovskaya, 2000). Впервые в основании чаплыгинской свиты единично появляются виды, не отмечавшиеся в нижних частях разреза (Archaeoperisaccus sp.). Общий систематический состав и процентные соотношения видов позволяют скоррелировать комплекс ПК2 с комплексом основания зоны Raistrickia bucera. Bepоятнее всего, ПК2 представляет 1-ую фразу неполного развития миоспор зоны R. bucera, которую мы назвали R. bucera-1. ПКЗ, установленный в средней части существенно глинистой пачки, характеризуется самым богатым таксономическим составом миоспор чаплыгинской свиты и сопоставляется с комплексом миоспор зоны Raistrickia bucera из средней части желонских слоев Беларуси. Этот уровень представляет более полную и обильную фразу развития, для которой предлагается название R. bucera-2. ПК4 из самой верхней части разрезов чаплыгинской свиты скоррелирован с миоспорами зоны Sinuosisporis vermiculatus-SV, выделенной в верхних частях желонского горизонта. Установленные в чаплыгинской свите зона R. bucera (с предлагаемыми двумя фазами развития) и зона Sinuosisporis vermiculatus позволяют уточнить принадлежность ее нижних частей к нижнетиманскому подгоризонту нижнефранского подъяруса. 


\section{Экспедиция Р.И. Мурчисона в г. Вязники и установление пермской системы}

Сенников А.Г.

Палеонтологический институт им. А.А. Борисяка Российской академии наук, Москва, Россия; sennikov@paleo.ru

Казанский (Приволжский) федеральный университет, Казань, Россия

В результате экспедиции Р.И. Мурчисона в 1840-1841 гг. была выделена пермская система, единственной установленная на территории нашей страны. В 1840 г. участники экспедиции на участке от Красноборска до Великого Устюга впервые увидели отложения, отнесенные впоследствии к пермской системе, но не смогли тогда определить их возраст, в том числе из-за отсутствия находок окаменелостей.

В 1841 г. Р.И. Мурчисон именно в Вязниках впервые увидел те отложения, которые позднее будут выделены в качестве пермской системы, а их описание легло в основу характеристики ее верхнего отдела. Таким образом, район Вязников следует относить к типовому региону данной системы. Р.И. Мурчисон с Н.И. Кокшаровым детально обследовали и описали выходы красноцветных и пестроцветных песков и глин в оврагах и в обрыве р. Клязьмы к востоку от города. Ими были обнаружены остатки остракод, двустворчатых моллюсков и чешуя рыб. Ключевое значение этих наблюдений в Вязниках заключается в том, что, изучив морские каменноугольные отложения окрестностей Москвы и Владимира, Мурчисон увидел, что их перекрывают пермские континентальные красноцветы у Вязников, то есть окончательно стало понятно соотношение этих двух систем. В завершающем капитальном труде «Геологическое описание Европейской России и хребта Уральского» в сводном разрезе вязниковские пески и глины совершенно правильно были помещены в верхах перми. Эти же отложения они наблюдали, распознали как одновозрастные и описали от Вязников до Гороховца и от Горбатова до Нижнего Новгорода.

Работа выполнена в рамках государственной программы повышения конкурентоспособности Казанского (Приволжского) фредерального университета среди ведущих мировых научно-образовательных центров. 


\section{Геология углеродистых отложений Сухарышской синклинали (Южный Урал)}

Сначев А.В.

Институт геологии УФИЦ РАН, Уфа, Россия; SAVant@rambler.ru.

Черные сланцы часто являются рудогенерирующими или рудовмещающими толщами в крупнейших месторождениях золота в мире. В связи с этим, автором уделено особое внимание Сухарышской синклинали расположеной в Копейско-Брединской подзоне Алапаевско-Адамовской структурно-фрормационной зоны (Южный Урал). Здесь углеродистоглинистые сланцы и аргиллиты широко развиты в фрёдоровской толще (C2fd), выходы которой наблюдаются в разрезах вдоль реки Увельки и единичных придорожных карьерах. Мощность толщи порядка 1000 м, возраст отложений принят как средний карбон, башкирский век на основании определения многочисленной фауны.

Углеродистые сланцы и алевролиты фрёдоровской толщи преимущественно серого и темно-серого цвета, их слоистая текстура обусловлена наличием прослоев радиоляритов и нитевидных выделений углеродистого вещества в основной микрокристаллической кремнистой массе. Углеродистое вещество бурого цвета развито в виде рассеянной примеси и концентрируется в виде тончайших прожилков и слойков. Содержания органического углерода достигают $2.8 \%$, что делает породу совершенно непрозрачной и позволяет относить данные отложения к низкоуглеродистому типу, широко распространенному в пределах Южного Урала. Термический анализ показал, что органическое вещество соответствует высшим керитам, подвергшимся катагенезу и начальной стадии фации зеленых сланцев.

По данным химического состава были рассмотрены петрохимические особенности углеродистых сланцев и алевролитов Сухарышской синклинали (тугундинская (C1tg), биргильдинская (C1 bg), фредеровская (C2fd) толщи). На основе анализа стандартных классификационных диаграмм показано, что сланцы и алевролиты попадают в поля терригенно-углеродистой и кремнисто-углеродистой фрормации, их осадконакопление происходило в локальных изолированных мелководных впадинах в коллизионной геодинамической обстановке. Терригенный материал формировался преимущественно за счет разрушения нижележащих пород основного и среднего состава березиновской толщи (C1bz), зрелость осадков последовательно увеличивается во времени от тугундинской к фрёдоровской толще.

Работа выполнена в рамках Государственного задания, тема № 0246-2019-0078. 


\title{
Байтуган, Камышла и Бузбаш - разрезы казанского яруса на р. Сок, Самарской области
}

\author{
Сонин Г.В. ${ }^{1}$, Коссовая О.Л., Дитер Вейер, Сонина О.Г. ${ }^{2}$ \\ ${ }^{1}$ Казанский (Приволжский) федеральный университет, Казань, Россия; g sonin@mail.ru \\ ²ВСЕГЕИ, Санкт-Петербург, Россия
}

Впервые разрезы перми на р.Сок посещались в начале 1900-х годов А.А.Штукенбергом, А.В. Нечаевым и А.Замятиным (1911 и 1913), затем в послевоенное время Н.Н.Форшем $(1951,1955)$, А.И.Осиповой и А.Д.Григорьевой $(1958,1960,1962)$. Сводная работа с учетом их результатов опубликована Е.И.Тихвинской и М.Г.Солодухо (1977).

Во время приближающегося юбилея 150-летия пермской системы разрезы р Сока изучались Г.В.Сониным (1989-1991). Результаты членения разреза в Русском Байтугане и открытия 8-и неизвестных в нем видов и 2-х подвидов опубликованы Г.В.Сониным и М.Г.Солодухо (1998). В последующие годы (до 2004) собранные коллекции дополнились сборами Г.В Сонина с участием студентов КГПИ и аспиранта И.Юсупова, В.В.Силантьева с аспирантом О.Клевцовым и экспедициями с участием российских (В.Г.Ганелин, О.Л.Коссовая, А.В.Журавлев и С.Б.Шишлов ) и иностранных участников (Дитер Вейер). По результатам этих сборов было сделано много публикаций в основном по схеме стратиграфии заданной еще Н.Н.Форшем и описаниям разреза сделанного совместно Г.В.Сониным, Д.Вейером и О.Л.Коссовой с обильными сборами фауны нашими коллекторами студентами О.Сониной и М.Галкиной в 2006 г.

Наше описание разреза 1989-1990-х г. и 2004-2006 г. значительно уточняет описание Н.Н.Форша за счет дополнительно изученных разрезов вскрытых новыми карьерами у Татарского и Чувашского Байтугана, урочища Ермак и поселка Бузбаш. Им пользовалась Н.К.Есаулова и др.(2004), где на стр. 34а этой статьи приведен наш разрез с ошибочным указанием авторства - Есаулова,1996, без упоминания настоящих авторов. Добавлю для ясности, что все визуально замеренные в поле мощности слоев, пачек слоев и их общая мощность уточнены с помощью приборной ватерпасовки структурных террас и выходов маркирующих пластов, проделанной нами с Ильфаром Юсуповым, который и представил наши уточненные материалы Н.К.Есауловой по ее просьбе.

По материалам наших сборов фауны сделано множество квалифицированных определений самыми разными специалистами: кораллов- О.Н. Коссовой, Д.Вейером и М.Г.Солодухо, брахиопод - М.Г.Солодухо и В.Г.Ганелиным, гастропод - А.Мазаевым, фораминифер - В.М.Игониным, конулярии - О. Сониной и студентами г. Томска под руководством С.А.Родыгина. Кстати В.Г.Ганелин устно сообщил, что фрауна брахиопод с байтуганского разреза, его нижней части, т.е. из пачки лингуловых глин указывает на их уфимский возраст, а вовсе не казанский, что симптоматично, поскольку и другие специалисты не однажды высказывали такую же точку зрения на эту фауну брахиопод. Свою коллекцию 1989-1990-х гг., определенную моими студентами с помощью М.Г.Солодухо, я вынужден был подарить Естественно-научному музею г. Казани, где ее и осмотрела в свое время Т.Г.Грунт, поскольку музей КГУ в то время не пожелал ее принять, а часть материалов, подаренных М.Г.Солодухо просто пропала.

В статье Е.И.Тихвинской и М.Г.Солодухо (1977), не видевших разрезов на р. Сок, допущена досадная ошибка - там сказано, что лингуловые глины низов казанского яруса залегают на красноцветах уфимской свиты. Должен поправить - на р.Сок нигде «лингуловые глины» или байтуганские слои Н.Н.Форша с диелязмами в основании нигде не ложатся на 
уфимские красноцветы, поскольку на Соке их просто нет, везде уфимские слои представлены серыми тонкослоистыми песчаниками иногда с включениями углистых остатков древесины (в карьере урочища Ермак и у Русского Байтугана) с врезанными в них мощными линзами шугуровских грубозернистых косослоистых дельтовых песчаников. Диелязмовый слой почти везде присутствует в основании казанского яруса и выше него идут черные лингуловые глины с мелкими конкрециями серого мергеля, содержащими лингул и мелких фрораминифрер, так что нижняя граница казанского яруса здесь четко прослеживается и сопровождается некоторым перерывом осадконакопления. В Бузбашском карьере нижележащие слои уфимских отложений представлены переслаиванием серых горизонтально-слоистых грубозернистых песчаников и мергелей мощностью более 5-10 м, которые ложатся на белые закарстованные известняки сакмарского яруса, иногда содержащие заполненные битумом раковины фузулинид (в урочище Ермак и у пасеки). Горизонтально - слоистые уфимские песчаники по своему минералогическому и гранулометрическому составу очень похожи на вышележащие косослоистые шугуровские песчаники, возможно являющиеся следствием переноса и перемыва первых в прибрежной зоне опресненного отчасти морского бассейна. Из этих известняков по трещинам в толщу уфимских песчаников внедряются жидкие блестящие на солнце битумы. Граница нижнеказанских отложений тут на коротких расстояниях сильно изменяется по абсолютным отметкам, облекая вместе с уфимскими слоями выступы сакмарских и возможно артинских известняков, слагающих ядро Сокско-Шешминского вала. Все это было зафиксировано на фотопленку Д.Вейером и О.Л.Коссовой и представлено на фотографиях презентации студенческой курсовой работы Сониной Ольги в 2007 году.

По договоренности с Дитрихом Вейером и О.Л.Коссовой описание разреза сделано Г.Сониным с указанием их как соавторов в специальной статье с учетом всех накопившихся материалов, как у основного исследователя разрезов на р. Сок с 1989-2000 гг. и проводника совместных экспедиций 2004-2006 гг. Здесь приводится ее краткое резюме ввиду громоздкости описания самого разреза. 


\section{Новые геохимические данные для приграничного интервала касимовского и гжельского ярусов в разрезе Усолка, Южный Урал}

Сунгатуллина Г.М., Сунгатуллин Р.Х., Буслаев Р.В.

Казанский (Приволжкий) фредеральный университет, Казань, Россия; sungatulina65@mail.ru

Наиболее интересные разрезы карбона как потенциальные кандидаты GSSP расположены на Южном Урале на территории Республики Башкортостан. Одним из них является разрез Усолка, после его расчистки в 2019 г. получены новые геохимические данные по касимовским и гжельским отложениям.

Для восстановления условий образования пород в позднем карбоне использованы петрохимические диаграммы. Так, на диаграмме $\mathrm{SiO}_{2} / \mathrm{Al}_{2} \mathrm{O}_{3}-\mathrm{K}_{2} \mathrm{O} / \mathrm{Na}_{2} \mathrm{O}$ все породы расположены в поле пассивной континентальной окраины. Анализ индекса химической изменчивости $\mathrm{ClA}=\left(\mathrm{Al}_{2} \mathrm{O}_{3} /\left(\mathrm{Al}_{2} \mathrm{O}_{3}+\mathrm{CaO}+\mathrm{Na}_{2} \mathrm{O}+\mathrm{K}_{2} \mathrm{O}\right)\right) \times 100$ показал, что на границе касимовского и гжельского ярусов наблюдается резкое снижение значений СІА в аргиллитах и туфрах, что может свидетельствовать о слабом выветривании пород Урала и непрерывном осадконакоплении на этой границе. Палеоклиматические условия позднекаменноугольного бассейна осадконакопления, восстановленные с помощью модуля $\mathrm{Al}_{2} \mathrm{O}_{3} / \mathrm{TiO}_{2}$, показали, что значительная часть изученного интервала разреза формировалась в условиях аридного климата.

Также выполнены исследования стабильных изотопов углерода и кислорода. Значения $\delta^{13} \mathrm{C}$ изменяются от $2.45 \%$ до $-11.27 \%$ (среднее значение $-7.20 \%$ \%), а значения $\delta^{18} \mathrm{O}$ - от $1.98 \%$ до -21.5\% (среднее значение -3.8 \%). Результаты анализа изотопного анализа оригинальных образцов и данные предшественников показывают, что от московского к гжельскому ярусам в разрезе Усолка происходит утяжеление пород $\delta^{18} \mathrm{O}$ и облегчение $\delta^{13} \mathrm{C}$. Так, для московского яруса среднее значение $\delta^{13} \mathrm{C}$ равно $0.2 \%$, а для касимовского и гжельского ярусов $-3.02 \%$ и -8.05\% соответственно. В гжельском ярусе отмечаются самые легкие значения углерода, а в ассельском ярусе в Предуральском прогибе содержания $\delta^{13} \mathrm{C}$ приближаются к нормальным морским значениям.

Одним из способов изучения условий осадконакоплений является анализ на содержание общего органического углерода (ТОC), который впервые проведен для 25 образцов из касимовских и гжельских отложений разреза Усолка. Поведение ТОС волнообразное с колебаниями содержаний от 0.25 до 6.73 \%, что подтверждает фрлишевую природу данного разреза.

Таким образом, получены новые геохимические результаты по касимовским и гжельским отложениям разреза Усолка. Геохимические индексы показывают, что климат в позднекаменноугольную эпоху был аридным, а тектоническая обстановка, в которой формировались породы фрлишевого комплекса, соответствовала пассивной континентальной окраине. 


\section{Новый взгляд на геологическое строение района междуречья рек Ассель и Ускалык Южного Предуралья}

Сысоева А.О.

Геологический Институт РАН, Москва, Россия; sysoeva@ginras.ru

Предуральский передовой прогиб (ППП) - отрицательная геологическая палеоструктура, сформированная в позднем палеозое и парагенетически связанная с герцинским Уральским орогеном. Для восточного борта южного сегмента ППП характерны интенсивные дислокации. Верхнепалеозойские (верхнекаменноугольно - биармийские) толщи смяты здесь в систему сопряжённых субмеридиональных складок, осложнённых продольными взбросами и надвигами. Эту складчато-надвиговую систему принято называть Западноуральской зоной линейных складок (ЗУЗЛС). В строении ЗУЗЛС исследователями выделяются два структурных этажа. На западе этого района расположены поля распространения недислоцированной почти горизонтально залегающей верхнепермской красноцветной молассы (верхний структурный этаж), которая несогласно налегает на толщи, слагающие нижний структурный этаж. В строении нижнего этажа принято выделять два структурно-фрормационных комплекса: верхний - аллохтонный, и нижний - автохтонный. Аллохтонный комплекс сложен толщами, охватывающими верхнекаменноугольносакмарские стратиграфический диапазон, а автохтонный комплекс - терригенноэвапоритовыми толщами, соответствующими кунгурскому ярусу. Аллохтонный и автохтонный комплексы разделены поверхностью Сюреньского надвига пологого восточного падения. В литературе активно обсуждается нефтегазоносность этой части ППП. Исследователи связывают нефтегазопроявления с наличием неразведанных тектонически экранированных надвигом ловушек.

Актуальность исследования объясняется необходимостью корректировки общепринятого взгляда на геологическое строение этой части Южного Предуралья. Полученные результаты могут быть полезны при моделировании эволюции осадочного бассейна и углеводородных систем этой части ППП.

Цель исследования - геологическое картирование междуречья Ассель-Ускалык в Южном Предуралье, с дальнейшим составлением геологических схем и освещением в литературных источниках нового взгляда на строение.

В результате проведённых работ были уточнены границы распространения толщ этой части ЗУЗЛЗ, составлены новая схематическая геологическая карта района масштаба 1:25000 и геологический разрез вкрест простирания структур. 


\title{
Особенности выделения местных стратиграфических подразделений нижнего франа Главного девонского поля
}

\author{
Тарасенко А.Б., Матвеев В.П., Норова Л.П., Цинкобурова М.Г.
}

Санкт-Петербургский горный университет; Санкт-Петербург, Россия; Tarasenko AB@pers.spmi.ru, Matveev VP@pers.spmi.ru, Norova LP@pers.spmi.ru, Tsinkoburova MG@pers.spmi.ru

На современном этапе геологического картирования существует проблема сопоставления региональных и местных стратиграфических подразделений. Региональные стратоны (слои с географическим названием, горизонты) - основные картировочные подразделения в 50-60-е годы 20 века, выделены на биостратиграфической основе. Сейчас картирование территорий происходит с помощью местных подразделений - свит (Стратиграфический кодекс, 2006). При составлении геологических карт 2-3-го поколений приходится искать соответствие между границами слоев/горизонтов, отражающих относительное время, и вещественными границами картируемых свит. Выделение свиты подразумевает описание реального геологического тела с однозначно определяемыми литологическими границами, которые, как правило, не являются изохронными на большой площади и часто не совпадают с биостратиграфическими границами горизонтов или слоев. Возникает необходимость переизучения разрезов, в которых были выделены региональные стратиграфрические подразделения, с упором на характеристику структурно-вещественных особенностей геологических тел (свит), их взаимоотношений и мощностей.

На территории Главного девонского поля (ГДП) по современным требованиям (в свитах) закартирован, например, лист O-36-XIV (Вербицкий и др., 2001). По такому же принципу построен лист О-35-36, N-36 (Вербицкий и др., 2012), охватывающий территории Ленинградской, Псковской и Новгородской областей. На столь значительной площади в верхнедевонских образованиях выделяются две структурно-фациальные зоны (СФЗ) Прибалтийско-Ладожская на севере ГДП и Изборско-Ильменская - на юге. Нижний подъярус франа в Прибалтийско-Ладожской СФЗ начинается с важинской свиты, которую перекрывает сясинская свита. В Изборско-Ильменской зоне фрациальным аналогом важинской свиты является ям-тесовская, а сясинской - снетогорская свита и нижняя часть староизборской свиты (Вербицкий и др., 2012; Легенда..., 1999). На местной стратиграфической схеме граница важинской и сясинской свит, также как снетогорской и староизборской свит, показана изохронной. А верхняя граница староизборской свиты скользит во времени (Вербицкий и др., 1999; 2001). Диахронность границы с трудом опознаваемой свиты вызывает сомнения, поэтому интерес представляет соотношение на данном интервале разреза местных подразделений с региональными. Начало работы было положено описанием обнажений девона в Прибалтийско-Ладожской СФЗ. В ходе полевых исследований 2020-2021 гг. были осмотрены коренные выходы пород нижнего франа на правом берегу р. Сясь возле дер. Яхново. Здесь на отчетливой ровной кровле известняков среднего ордовика прослеживается маломощный $(0,1 \mathrm{~m})$ слоек голубовато-серой глинистотерригенной породы (глинистых частиц 27.4\%, пылеватых 46.6\%, песчаных $26.0 \%$ ), которую с размывом перекрывают светло-серые, известковистые, косослоистые песчаники (0.3 м) с обильными интракластами подстилающих глин и единичными переотложенными скелетами эндоцератоидей. Кровля песчаников покрыта слойком $(0,1 \mathrm{~m})$ фриолетово-бурой $и$ зеленовато-серой тонкослоистой глины (глинистых частиц $38.8 \%$, пылеватых $21.6 \%$, песчаных 39.6\%). Вышележащие 4 метра разреза характеризуются фррагментарными выходами пестроцветных глин и песчаников, над которыми обнажены белые и розовые 
слабосцементированные, горизонтальнослоистые песчаники (1.5 м), с частыми тонкими намывами слюдисто-глинистого материала. Сравнение литологических свойств пород на р. Сясь с описанием стратотипического разреза важинской свиты указывает на то, что именно эта свита обнажена в бортах речной долины. Материалы (Геккер, 1941) также ясно свидетельствуют о наличии важинской свиты в данной местности. Ранее Р.Ф.Геккер (Геккер, 1941) дал подробное описание снетогорских слоев у дер. Яхново на р. Сясь, не указав точного положения границы слоёв в разрезе. Возможно, поэтому на карте ГГК-1000 (Вербицкий и др., 2012) важинская свита на территории Южного Приладожья отсутствует.

Терригенный разрез важинской свиты на р. Сясь наращивается глинистокарбонатными породами, снизу вверх представленными: известняками (0.1 м) пестроцветными, микритовыми, глинистыми, песчанистыми, с раковинами брахиопод (Ladogia meyendorfi Verneuil) и обломками панцирей рыб; глинами (0.1 м) фриолетового и голубого цвета; известняками (0.1 м) буровато-красными, спаритовыми, с намывами песка и детрита, с обломками раковин брахиопод и панцирей рыб на кровле; известняками (0.4 м) голубовато-серыми, детритовыми, песчанистыми, с глинистыми интракластами, с комковатой отдельностью; глинами (0.2 м) фиолетового цвета (глинистых частиц 49.1\%, пылеватых 49.9\%, песчаных 1\%). Данные образования идентифицируются как сясинская свита (псковские слои Р.Ф. Геккера).

Отсутствие детальных палеонтологических сборов не позволяет точно судить о взаимоотношении границ свит и слоев с географическим названием. Рассмотренное обнажение нижнего франа отчетливо иллюстрируют сложности в расчленении разрезов на, казалось бы, хорошо изученной территории. Это связано, во-первых, с недостаточной литологической характеристикой свит в стратотипических разрезах, а зачастую и отсутствием описания характера их контактов. Во-вторых, с сильной изменчивостью свит (особенно терригенных) на местности даже в пределах одной фрациальной зоны. В-третьих, отсутствием надежного биостратиграфического контроля выделяемых местных стратонов. Решение проблемы авторы видят в переописании стратотипов региональных и местных стратиграфрических подразделений с применением комплекса методов изучения осадочных отложений и прослеживании латеральных рядов свит на местности. Такой подход позволяет рассматривать свиты как естественные геологические тела, имеющие свой состав и строение и формировавшиеся на определенных этапах развития региона. Одновозрастность или разновозрастность свит должна контролироваться не только геологическими, биостратиграфическими, а и циклостратиграфическими методами.

\section{Литература}

Вербицкий В.P. Диахронность границ местных стратиграфических подразделений на примере среднефранских отложений запада Российской части Главного девонского поля / В.Р. Вербицкий, А.В. Журавлев, Ю.П. Ненашев // Историческая и региональная геология в системе геологического образования. - 1999. - С.125-131.

Вербицкий, В.Р. Государственная геологическая карта Российской федерации масштаба 1:200 000 (издание второе). Серия Ильменская. Лист О-36-XIV (Новгород) / В.P. Вербицкий, Ю.П. Ненашев, А.В. Журавлев, Г.А. Русецкая. - Спб.: ФГУП «ВСЕГЕИ», 2001.

Вербицкий В.P. Государственная геологическая карта Российской Федерации. Масштаб 1:1000000 (третье поколение). Серия Центрально-Европейская. Листы О-35-Псков, (N35), О-36-Санкт-Петербург. Объяснительная записка / В.Р. Вербицкий, И.В. Вербицкий, О.В. Васильева, В.В. Саванин и др. - СПб.: Картографическая фрабрика ВСЕГЕИ, 2012. $-510 \mathrm{c}$. 
Геккер Р.Ф. Отложения, фауна и фрлора Главного девонского поля / Р.Ф. Геккер // Фауна Главного девонского поля, т. 1. - 1941. - С. 17-84.

Енгалычев С.Ю. Геохимия песчаников восточной части Главного девонского поля / С.Ю. Енгалычев, Е.Г. Панова. - СПб.: С-Петерб. ун-т, 2008. - 100 с.

Стратиграфический кодекс России. Издание третье. - СПб.: Издательство ВСЕГЕИ, 2006. $96 \mathrm{c.}$

Легенда Ильменской серии листов Государственной геологической карты Российской Федерации масштаба 1:200 000 (изд. 2-е) / под ред. В.П. Кирикова. - ГП ПКГЭ, 1999. 


\section{Углеродистые формации Магнитогорского прогиба (Южный Урал) и перспективы их нефтегазоносности}

Тюрин А.М. ${ }^{1,2}$, Коломоец А.В. ${ }^{1,2}$, Сначёв А.В. ${ }^{3}$, Смолева И.В. ${ }^{4}$, Панкратьев П.В. ${ }^{2}$ ${ }^{1} \mathrm{OOO}$ «ВолгоУралНИПИгаз», Оренбург, Россия; amturin1952@bk.ru

2 Оренбургский государственный университет, Оренбург, Россия; kolomoyets56@mail.ru

3 Институт геологии УФИЦ РАН, Уфа, Россия; SAVant@rambler.ru

${ }^{4}$ Институт геологии Коми НЦ УрО РАН, Сытывкар, Россия; smolewa@geo.komisc.ru.

Перспективы нефтегазоносности Магнитогорского прогиба Южного Урала обоснованы по результатам геологической съёмки и глубокого бурения. В Кизильской зоне по данным сейсмо-, грави- и магниторазведки выявлена крупная структура по карбонатам нижне-среднекаменноугольного возраста. По результатам бурения В них отмечены нефтегазопроявления.

Дальнейшее обоснование перспектив нефтегазоносности региона выполнено по особенностям характеристик чёрных сланцев Кумакского (C1t2v1) рудного поля и Сиратурского (O1-2pl) и Амурского месторождений (D2-3). Во внимание приняты содержание в них Сорг (органического вещества и графита), а также изотопный состав углерода. Показано, что сланцы Кумакского рудного поля являются:

- потенциально нефтематеринскими породами (находятся на стадии метаморфизма, характеризующейся переходом органического вещества в графит);

- депрессионными аналогами нефтегазоперспективных шельфовых карбонатов нижне-среднекаменноугольного возраста.

Рекомендовано продолжить изучение чёрных сланцев в контексте дальнейшего обоснования перспектив нефтегазоносности Южного Урала. Главные научные задачи локализацию в пределах Магнитогорского прогиба и Восточно-Уральского поднятия фаций бассейна карбонатной седиментации и разработка его геолого-геофизической модели, оценка на её основе перспектив нефтегазоносности региона и обоснование постановки региональных сейсморазведочных работ МОГТ.

Работа выполнена при фринансовой поддержке корпоративного гранта АО «Оренбургнефть» (2020-2021гг.) и в рамках Госзадания по теме № 0246-2019-0078. 


\title{
Палеомагнетизм пограничных пермо-триасовых осадочных пород Оренбургской области
}

\author{
Фетисова А.М. ${ }^{1,2,3}$, Веселовский Р.В. ${ }^{1,2}$, Голубев В.К. ${ }^{4,3}$
}

${ }^{1}$ Московский государственный университет имени М.В. Ломоносова, Ленинские горы, д.1, Москва, Россия; anna-fetis@yandex.ru

2Институт физики Земли имени О.Ю. Шмидта РАН, ул. Б. Грузинская 10, Москва, Россия ${ }^{3}$ Казанский (Приволжский) федеральный университет, ул. Кремлёвская 4/5, Казань, Россия

4 Палеонтологический институт им. А.А. Борисяка РАН, ул. Профсоюзная 123, Москва, Россия

Получение новых надежных палеомагнитных данных для пограничного пермотриасового интервала Восточно-Европейской платформы является актуальной задачей для уточнения и детализации региональной магнитостратиграфической шкалы, для построения тектонических реконструкций, для уточнения стратиграфической принадлежности разрезов и их корреляции на региональном и глобальном уровнях.

В рамках исследований были детально опробованы пять разрезов Оренбургской области: Боевая Гора, Вязовка, Красногор, Воздвиженка, Астрахановка. Палеомагнитная коллекция составила около 450 образцов. Разрезы сложены континентальными красноцветными терригенными породами. Все образцы прошли детальную температурную магнитную чистку, на некоторых дублях проводилась чистка переменным полем. Большинство образцов содержит хорошую интерпретируемую палеомагнитную запись, что позволило провести компонентный анализ и выделить характеристическую компоненту намагниченности (ChRM). В двух разрезах (Вязовка и Воздвиженка) ChRM исключительно обратной полярности, во всех остальных - прямой и обратной. Для каждого разреза было рассчитано среднее палеомагнитное направление и соответствующий палеомагнитный полюс.

Анализ пространственного распределения палеомагнитных полюсов показал, что «пермские» полюсы, полученные по разрезам Красногор и Воздвиженка, несколько смещены относительно «триасового» полюса разреза Астрахановка. Предварительно это может указывать на значительную разницу в возрасте изученных разрезов или свидетельствовать о возможных относительных перемещениях (вращениях) тектонических блоков в составе Восточно-Европейской платформы в пост-палеозойское время.

Исследования проведены при поддержке гранта РФФИ № 18-05-00593 и за счёт средств субсидии, выделенной Казанскому федеральному университету для выполнения государственного задания № 671-2020-0049 в сфере научной деятельности. 


\title{
Магнитостратиграфическая шкала пограничных отложений перми и триаса Восточно-Европейской платформы
}

\author{
Фетисова А.М. ${ }^{1,2,4}$, Голубев В.К. ${ }^{3,4}$, Веселовский Р.В. ${ }^{1,2}$, Балабанов Ю.П. ${ }^{4}$, Наумчева
} M.A. ${ }^{3,4}$

${ }^{1}$ Московский государственный университет имени М.В. Ломоносова, Ленинские горы, д.1, Москва, Россия; anna-fetis@yandex.ru, roman.veselovskiy@ya.ru

${ }^{2}$ Институт физики Земли имени О.Ю. Шмидта РАН, ул. Б. Грузинская 10, Москва, Россия

ЗПалеонтологический институт им. А.А. Борисяка РАН, ул. Профсоюзная 123, Москва, Россия; vg@paleo.ru, paleomasha@mail.ru

4Казанский (Приволжский) фредеральный университет, ул. Кремлёвская 4/5, Казань, Россия; balabanov-geo@mail.ru

Традиционная магнитостратиграфическая шкала пограничных отложений перми и триаса Восточно-Европейской платформы представлена следующей последовательностью магнитозон: $N_{2} P, R_{3} P, N_{1} T$ и $R_{1} T$. В составе зоны $R_{3} P$ выделяют субзоны $r_{1} R_{3} P, n_{1} R_{3} P, r_{2} R_{3} P$ (Burov et al., 1998; Молостовский и др., 2001; Hounslow, Balabanov, 2018). Иногда в кровле зоны $\mathrm{R}_{3} \mathrm{P}$ выделяют субзону $\mathrm{n}_{2} \mathrm{R}_{3} \mathrm{P}$, подразумевая наличие крупного регионального перерыва на границе перми и триаса (на границе $\mathrm{R}_{3} \mathrm{P} / \mathrm{N}_{1} \mathrm{~T}$ ).

Нами были проведены детальные магнитостратиграфические и биостратиграфические исследования типовых и опорных разрезов пограничных отложений перми и триаса в бассейнах рек Ока, Сухона, Малая Северная Двина и Юг. Результаты этих исследований позволили ревизовать магнитостратиграфическую шкалу и уточнить положение магнитозон в региональном разрезе.

Наличие крупного регионального перерыва на границе перми и триаса не подтвердилось (Golubev, 2019). Нижняя граница триаса располагается в нижней части вохминского горизонта, внутри остракодовой комплексной зоны Suchonellina mera - Gerdalia variabilis. Она приурочена к зоне прямой полярности $\mathrm{N}_{3} \mathrm{P}-\mathrm{T}$, объединяющей субзону $\mathrm{n}_{2} \mathrm{R}_{3} \mathrm{P}$ и зону $\mathrm{N}_{1} \mathrm{~T}$ прежней шкалы. Нами установлено более сложное строение зоны $\mathrm{R}_{3} \mathrm{P}$, в составе которой выделены три субзоны обратной полярности и две субзоны прямой полярности. На этом основании индекс магнитозоны изменён на RnP. Таким образом, современная магнитостратиграфическая шкала пограничных отложений перми и триаса ВосточноЕвропейской платформы представлена магнитозонами $\mathrm{N}_{2} \mathrm{P}, \mathrm{RnP}$ (в составе субзон $\mathrm{r}_{1} \mathrm{RnP}$, $n_{1} R n P, r_{2} R n P, n_{2} R n P$ и $\left.r_{3} R n P\right), N_{3} P-T$ и $R_{1} T$.

Нижняя граница магнитозоны RnP располагается в верхней части быковского горизонта. Внутри субзоны $r_{1} R n P$ располагается граница быковского $и$ нефёдовского горизонтов, внутри субзоны $r_{3} R n P$ - граница нефёдовского и жуковского горизонтов, внутри зоны $\mathrm{N}_{3} \mathrm{P}-\mathrm{T}$ - граница жуковского и вохминского горизонтов. Нефёдовский горизонт по фауне остракод делится на две части: нижнюю, слои с Suchonella typica, и верхнюю, слои с Suchonella clivosa (Наумчева, Голубев, 2019; Наумчева, 2020). Нижняя граница субзоны $\mathrm{n}_{1} \mathrm{RnP}$ приурочена к слоям c Suchonella typica, нижние границы субзон $\mathrm{r}_{2} \mathrm{RnP}, \mathrm{n}_{2} \mathrm{RnP}$ и $\mathrm{r}_{3} \mathrm{RnP}$ локализованы внутри слоёв с Suchonella clivosa.

Исследования проведены при поддержке гранта РФФИ № 18-05-00593 и за счёт средств субсидии, выделенной Казанскому федеральному университету для выполнения государственного задания № 671-2020-0049 в сфере научной деятельности. 


\title{
Детритовая геохронология циркона пограничных пермь-триасовых отложений разреза Боевая Гора (Оренбургская область)
}

\author{
Чистякова А.В. ${ }^{1}$, Веселовский Р.В. ${ }^{1,2}$, Ковач В.П. ${ }^{3}$, Марфин А.Е. ${ }^{4}$, Фетисова А.М. ${ }^{1,2}$, \\ Голованова Т.И. ${ }^{5}$ \\ ${ }^{1}$ Московский государственный университет им. М.В. Ломоносова, Москва, Россия; \\ sinematograf11@yandex.ru \\ ${ }^{2}$ Институт физики Земли РАН, Москва, Россия \\ ${ }^{3}$ Институт геологии и геохронологии докембрия РАН, Санкт-Петербург, Россия \\ ${ }^{4}$ Институт земной коры Сибирского отделения РАН, Иркутск, Россия \\ ${ }^{5}$ Институт геологии рудных месторождений, петрографии, минералогии и геохимии РАН, Москва, \\ Россия
}

Проблема разработки детальных шкал магнитной полярности пограничных пермотриасовых разрезов Русской плиты до сих пор является актуальной и активно разрабатывается нашим коллективом начиная с 2014 года. Однако для составления сводной магнитостратиграфической шкалы верхней перми и нижнего триаса ВосточноЕвропейской платорормы, необходимо выполнение внутри- и межбассейновой корреляции опорных разрезов. Ранее, на примере бассейна Московской синеклизы, нами было показано, что результаты U-Pb датирования зёрен обломочного циркона хорошо отражают реорганизацию питающих провинций терригенных отложений Русской плиты на рубеже палеозоя и мезозоя и могут рассматриваться как дополнительный и независимый инструмент корреляции. В рамках развития данного подхода, а также для расширения представлений о палеогеографической обстановке в пермь-триасовое время, мы отобрали три пробы для выделения зёрен обломочного циркона из разреза Боевая Гора - одного из наиболее представительных пограничных пермь-триасовых разрезов Оренбургской области. Две пробы были отобраны из нижнетриасового интервала и одна из верхнепермского. Датирование методом LA-ICP-MS проводилось в ИГГД РАН (Санкт-Петербург) и ИЗК СО РАН (Иркутск), исследования катодной люминесценции циркона выполнены в ИГГД РАН и ИГЕМ РАН.

По результатам выполненного U-Pb LA-ICP-MS датирования наиболее отчетливо выделяются ранне- и позднедевонские возрастные максимумы, а также пик с модальным значением около $530 \mathrm{mлн.} \mathrm{лет.} \mathrm{Таким} \mathrm{образом,} \mathrm{основными} \mathrm{источниками} \mathrm{кластического}$ материала, вероятно, служили как кристаллические комплексы Уралид (широко развитые на уровне современного эрозионного среза Урала и охарактеризованные многочисленными изотопными датировками), так и реликты Протоуральско-Тиманского орогена (в настоящее время фрактически отсутствующие в пределах региона). Кроме того, отмечается статистически значимое различие между возрастными спектрами, полученными для верхнепермского и нижнетриасового интервалов разреза. 
Kazan Golovkinsky Stratigraphic Meeting 2021, celebrating the 180th anniversary of the establishment of the Permian system

Sedimentary Earth Systems: Stratigraphy, Paleoclimate, Geochronology, Petroleum Resources

\title{
Sixth All-Russian Conference "Upper Paleozoic of Russia"
}

October 18-22, 2021, Kazan, Russia

\section{Abstract Volume}

\author{
Международная конференция \\ Kazan Golovkinsky Stratigraphic Meeting 2021, \\ посвященная 180-летию со дня установления пермской системы \\ Осадочные системы: стратиграфия, геохронология, палеоклимат, \\ углеводородные ресурсы

\section{Шестая Всероссийская конференция «Верхний палеозой России»} \\ 18-22 октября 2021, Казань, Россия
}

\section{Сборник тезисов}

Компьютерная верстка

Дизайн обложки

Подписано к использованию 2021. Формат 60x84 1/16. Гарнитура «Arial».

Усл. печ. л. Заказ

Издательство Казанского университета 